\title{
DOF/OR/0305 4-TH(OQPR.A) MASTER
}

Department of Energy

Oak Ridge Operations

P.O. Box E

Oak Ridge, Tennessee 37830

KENTUCKY DEPARTMENT FOR NATURAL RESOURCES AND ENVIRONMENTAL PROTECTION

\section{PERMIT APPLICATION FOR AIR CONTAMINANT SOURCE}

\section{SRC-I DEMONSTRATION PLANT}

NEWMAN, KENTUCKY

APPENDIX A

"Kentucky Permit Application

Forms APC-110A, APC-110B, APC-110C" 


\section{DISCLAIMER}

This report was prepared as an account of work sponsored by an agency of the United States Government. Neither the United States Government nor any agency Thereof, nor any of their employees, makes any warranty, express or implied, or assumes any legal liability or responsibility for the accuracy, completeness, or usefulness of any information, apparatus, product, or process disclosed, or represents that its use would not infringe privately owned rights. Reference herein to any specific commercial product, process, or service by trade name, trademark, manufacturer, or otherwise does not necessarily constitute or imply its endorsement, recommendation, or favoring by the United States Government or any agency thereof. The views and opinions of authors expressed herein do not necessarily state or reflect those of the United States Government or any agency thereof. 


\section{DISCLAIMER}

Portions of this document may be illegible in electronic image products. Images are produced from the best available original document. 
Department of Energy Oak Ridge Operations P.O. Box E

Oak Ridge, Tennessee 37830

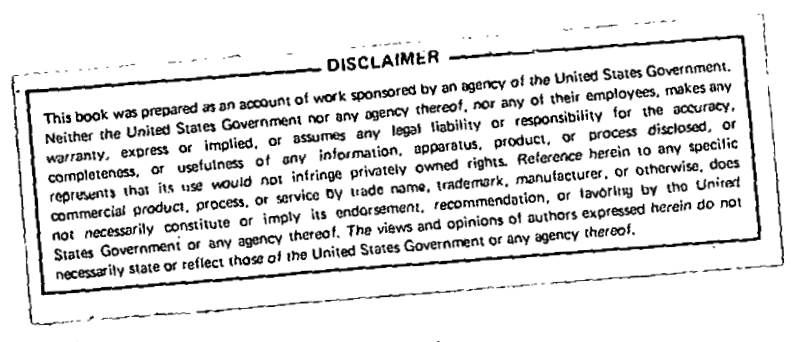

KENTUCKY DEPARTMENT FOR NATURAL RESOURCES AND ENVIRONMENTAL PROTECTION

\section{PERMIT APPLICATION FOR AIR CONTAMINANT SOURCE :}

\section{SRC-I DEMONSTRATION PLANT}

NEWMAN, KENTUCKY $\odot$ 3"

C. Tentucky Permit Application Formis 
KENTUCKY PERMIT APPLICATION FORMS

SECTIONS $5.0,6.0$ AND 7.0

Table of Contents

SECTION 5.0 - APC-110A INDIRECT HEAT EXCHANGERS

Area 12 Coal Slurry Heaters

Vacuum Column Heater

CSD Heater

Hot 0 il Heater

Area 13 Coking Heater

Hydrocracker Heating System

Vacuum Tower Heater

Area 15 Gasifier Heater

Shift Startup Heater

Area 16 0il Fired Boiler

Dowtherm Heater

SECTION 6.0 - APC-110B MANUFACTURING OR PROCESSING OPERATIUNS

Area 11 Coal Storage and Transfer

Area 12 SRC Process

Area 13 Coke and Liquid Fue 1

Area 14 Air Separation

Hydrogen Purification

Area 15 Gas Systems

SECTION 7.0 - APC-110C INCINERATORS AND/OR WASTE BURNERS

Area 12 Vent Waste Incinerator

Area 13 Rotary Kiln

Area 15 Gasifier Startup Flare

Pilot Flame

Thermal Oxidizer

Area 16 Flare Tower 


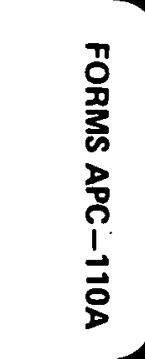




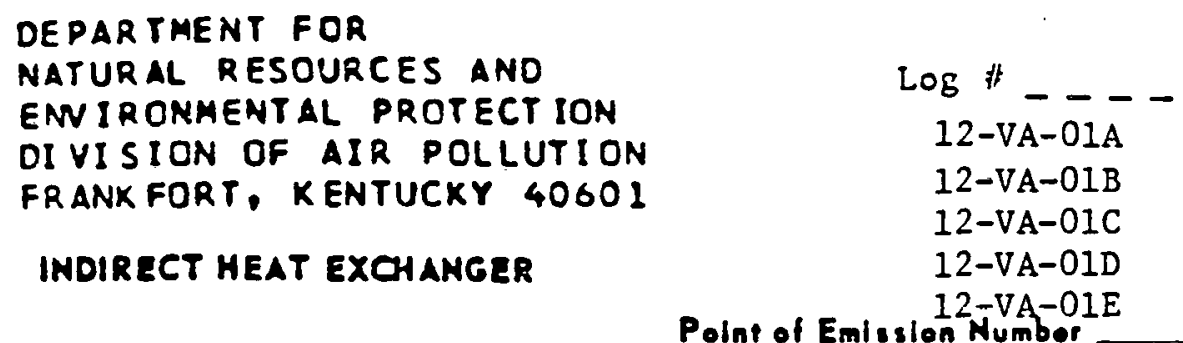

1. A completed form (No. APC $110 A$ ) shall bo submitted for each individual unit. The following ypos 12-VA-01F from this portion of tho opplication:

A Indirect heot exchangers usod sololy for heoting residential buildings not excooding a total of six oportmont units;

B. Now installations with o copocity of less then 1 million BTU por hour input;

C. Now installotions using notural or liquified patroleum gos, including thoso hoving distilloto fual oil os standby fuel with o capacity of lass than 50 million BTU por hour input;

D. Marine installations and locomotives;

E. Intornal combustion engines and vohicles usod for transportation of passongers or frought.

If your indirect heat exchanger is in one of the above categories please check that catego and complete only items $7,8,9$.

Now installotions are those for which construction commenced ofter Aprll 9, 1972

2. Typo of Unir H-12301 Coal Slurry Heater i- A Monufocturor's Nomo TBD

B. Monufacturer's Hodel Number

TBO

C Date Installed

NA

3. Ratod Capastiy-Inpup (BTU/Mr.) 335 million

4. Type of Combustion Unit (Cod) With fly ash rolniection Without fly ash roinjection NA
A. Pulvorized
Dry Bottom
C. Stoker-fired
Wot Bottom
Sprooder Stoker
Other Stoker
B. Cyclone
D. Hand-fired
E. Orher (Specify)

5. Typo of Combustion Unit (oil) Not yet determined.
A. Tangentially-firod
B. Horizontally-firod

6. Type of Combustion Unit (Wood) NA

With fly osh roinioction

Without fly osh reiniection
A Pile
B. Thin Bod
C. Cyclonic 
1. Typo and wuontity of Fual (List ssth primary and stondbr):
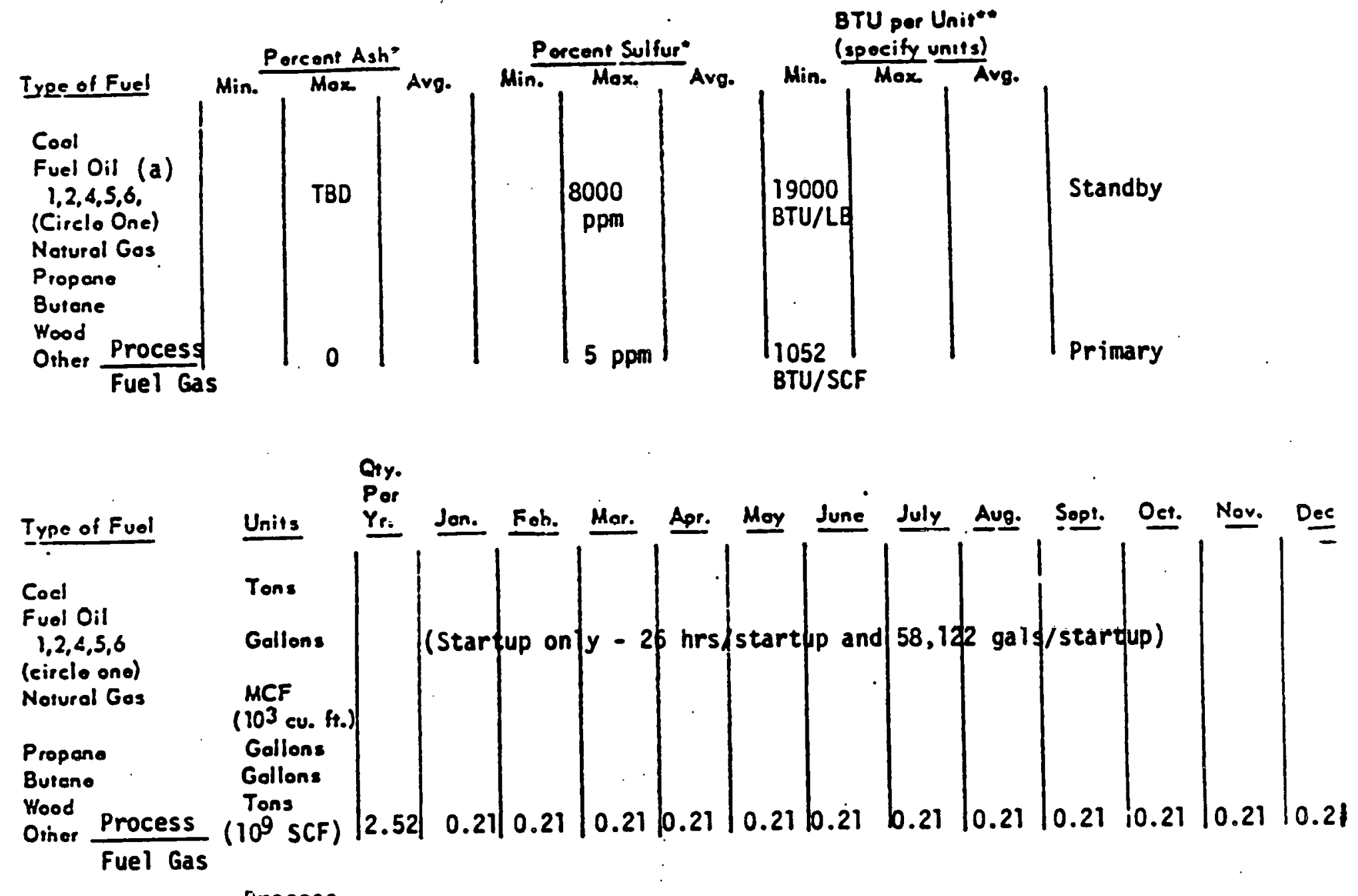

8. Fuol Sourcs

Process

9. Normal Ofa: oting Schodula:

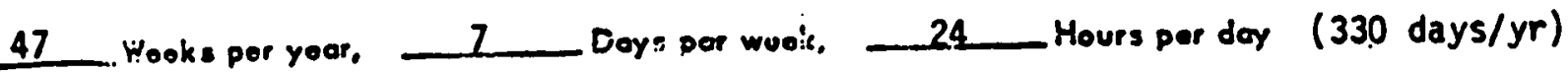

- As rocoivód bosiz (Proximate onolysis for ash, ultimato onolyais for sulfur)

-. Highor hooring volue.

(a) Process Fuel 011 
10. Purpose (If multipurpose, deseribe parcent in each use coragony)

Soaco Hoat

Process Hoot 100\%

Powor

11. Typo of Control Equipment

\section{Control Efficiency \\ Particulates $\mathrm{SO}_{2}$ Other (Specify)}

Bosis of Estimote

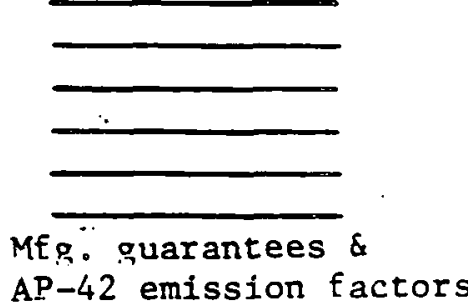

AP-42 emission factors
Eloctrostatic Procipitator

Cyelóne

Multiple Cyelone

Wor Serubber

(3)

Sortling Chanber

Orher (Spocity)

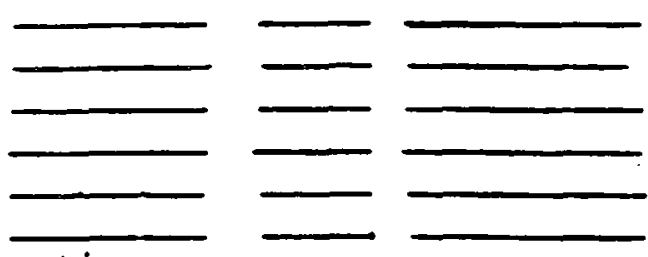

$16-2 / 3 \%$ of fuel g,as)
A. Outlot tomporature
400 $\bullet \boldsymbol{F}$
B. Outlat velocify $\mathrm{fg} / \mathrm{sec}$
C. Hoight 150 foot
D. Inside diametor (ourlot) inches

(4) E. Number of sompling ports providod Not yet available

(4) F. Neorest distance from sompling port downetrean to stock outlat, bend or obstruction Not yet avail able foet

(4) G. Noarest distance from sampling port upstroan to bend or obstruetion Not yet avai lable foet

H. List other sources vented to this stock (See Item 14)

13 Combustion oir: Notural draft Indueod "Balanced Draft"

Foreod prossure Brolsqin.

Excess air (sotal oir supplied in excess of theorotical air required) 5 $\%$

14. Doscribe fuel tronsport, storage mothods and rolated dust control moesures.

This unit will be used both as a process heater and as an incinerator. Refer to the appropriate segments of Section 8.0 "BACT Proposals" for descriptions and operations.

15. Describe fly ash (or other collected air confeminents) disposal, ransportation mothods and roloted dust control moasures.

WA

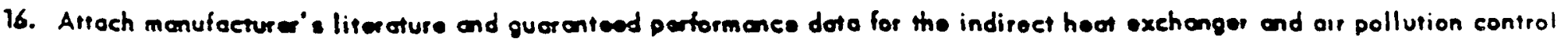
equipment. Include information concerning fuel input, bumers and combustion chamber dimensions.

Information not available yet but will be provided as soon as available.

(4) Sampling ports and access equipment will be provided to comply with Kentucky Air Pollution Control Regulations $401 \mathrm{KAR} 50: 45$ and 401 KAR 50:015. 
DEPAR TMENT FOR

NATURAL RESOURCES AND

ENNIRONMENTAL PROTECTION

$\log \#-\ldots$

OIVISION OF AIR POLLUTION

FRANK FORT, KENTUCKY 40601

INDIRECT HEAT EXOHANGER

Point of Emission Number 12-VA-02

1. A completed form (No. APC 110 A) sthall be eubmitted for each individual unit. The following types of units are exempted from this portion of the epplication:

A Indirect hoot exchengers used sololy for hooting rosidential buildings not excooding o total of six coarment units;

B. Now installations with a copocity of less then 1 million BTU por hour input;

C. Now installotions using natural or liquified potroleum gos, including shose hoving distillate fuel oil os standby fuel with o copacity of less than 50 million BTU por hour input;

D. Marine installations and locomotives;

E. Internal combustion engines and vohicles uead for rronsportation of passongers or freight.

If your indirect heat exchanger is in one of the above categories please check that carege and complete only items $7,8,9$.

Now installotions ore those for which construction commenced ofter April 9, 1972

2 Type of Unit H-12601 Vacuum Column Heater _. A Monufocturep's Namo

B. Monufocturor's Hodal Number TBD

C Dote Instailed

NA

3. Roted Copactiy-Input (BTU/Hr.) 23 mililion

4. Typo of Combustion Unis (Cod) With fly osh roiniection Without fly ash roinjection NA
A. Pulverized
Dry Bottom
C. Stoker-fired
Wot Bottom
Sprooder Stoker
Other Stoker
B. Cyclone
D. Hond-fired
E. Othor (Spoeity)

5. Type of Combustion Unit (oil) Not yet determined.

A. Tangentialiy-firod

B. Horizontally-fired

6. Type of Combustion Unit (Wood) NA

With fly ash reiniection

Without fly ash reinlection
A Pile
8. Thin B.d
C. Cyclonie 
Typo and Quontiry of Fual (List both primory and stondby):
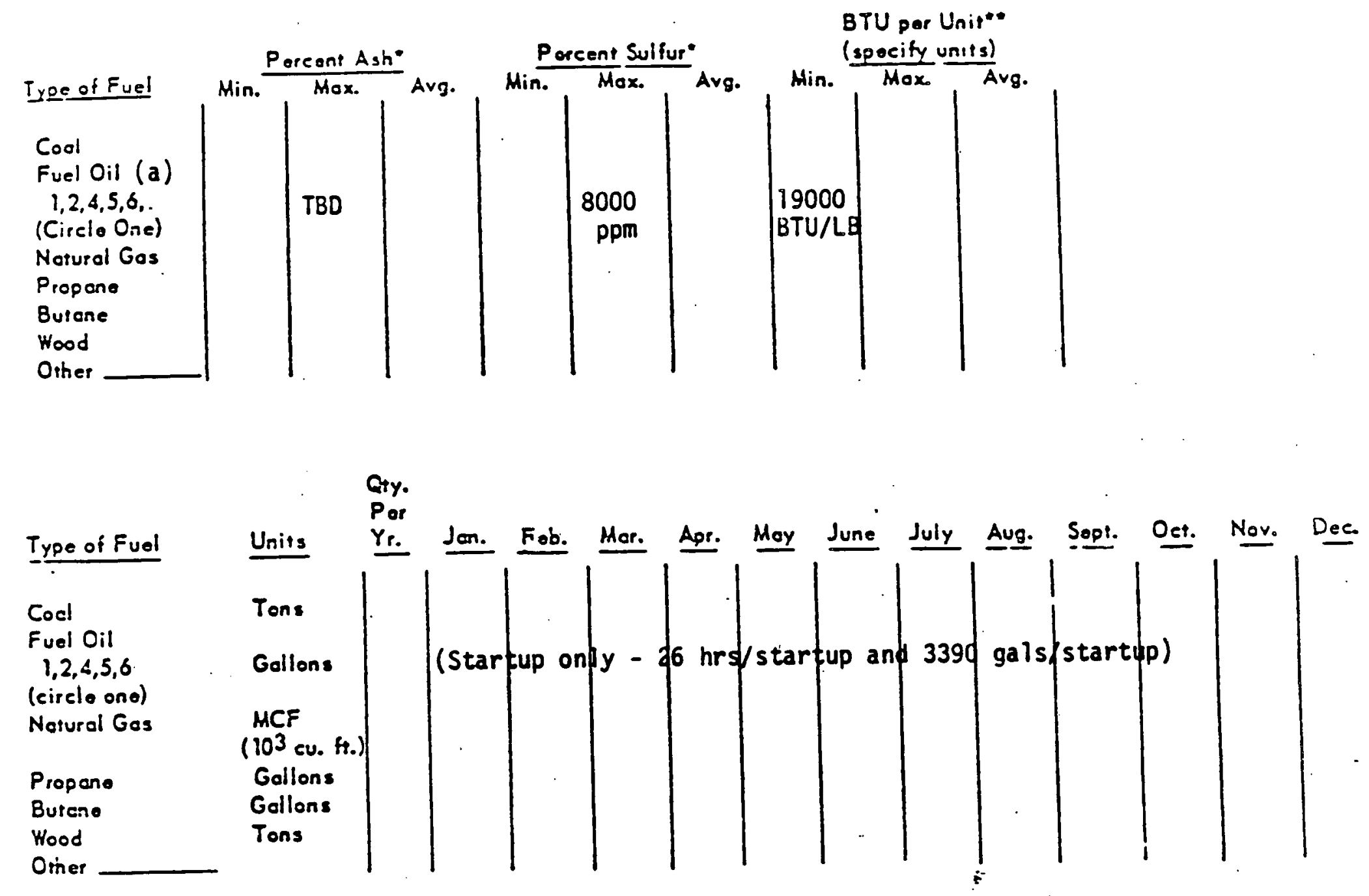

8. Fual Sourco Process

9. Normal Oporoting Schoduls: Startup Only Hooks per yoor, Coys por wook. Mours per doy

- As rocoived basiz (Proximate analysis for ash, ultimoto onolysiz for sulfur)

$\because$ Higher hooring valua.

(a) Process Fuel 0 il 
10. Purpose (if multipurpose, describe porcent in each use catesany)

Sooce Heat

Process Hoot $100 \%$

Powor

11. Type of Control Equipment

$$
\text { Particulatos } \frac{\text { Control Efficioney }}{\mathrm{SO}_{2} \text { Other (Specify) }}
$$

Electrostatic Precipitator

Cyclóne

Multiple Cyelone

Wos Serubber

Sottling Chanber

(3) Other (Spocity)

(3) Stock
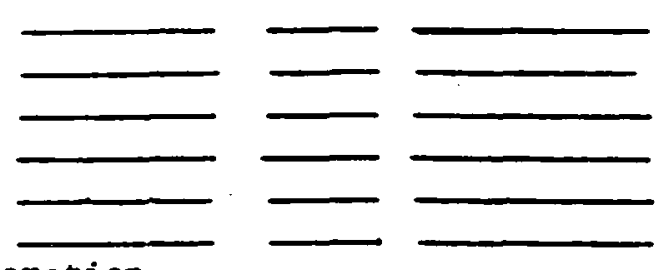
A. Outlot temperoture
$\bullet$
B. Outlat velocity
C. Hoight
150
50
$\mathrm{ft} / \mathrm{soc}$
D. Inside diameter (outlot)
loot

E. Number of sompling ports provided Not yet available.

** F. Noorost distance from sompling port downstroem to stock outlot, bend or obstruction Not yet availablaboet

$* *$ G. Noarest distance from sompling port upstrean to bend or obstruction Not yet available foot

H. List other sources ventod to this stock (See Item 14)

13. Combustion air: Natural draft Indueed "Balanced Draft"

Forced pressure Ibeselsin.

Excess oir (rotal oip suppliad in axcess of theoratical air required)

"ifg. guarantees \& $\mathrm{A}^{\mathrm{D}}-42$ emission factors

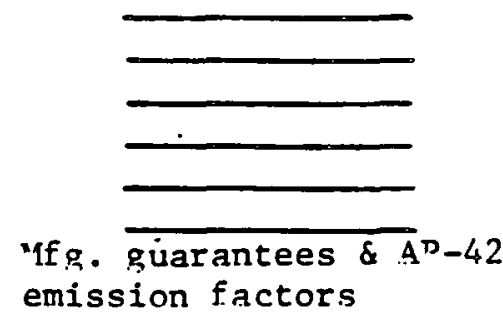

.14. Describe fuol transport, storoge methods and rolated dust control meosures.

This unit will be used as a process heater. Refer to the appropriate segment of Section 8.0 "BACT Proposals" for description.

15. Deseribe fly ash (or other collected air confominenis) disposeal, transportation mothods and rolotod dust control moosures. NA

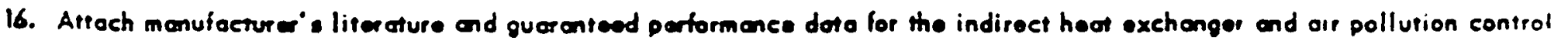
-quipmont. Include inform ation concerning tual input, bumere and combustion chomber dimensions.

Information not available vet but will be provider as soon as available.

*: Sampling ports and access equipment will be provided to comply with Kentucky Air

Pollution Contr-1 Regulations 401 KAR 50:45 and 401 KAR 50:015. 
DEPARTMENT FOR

NATURAL RESOURCES AND

EN IRONAENT IL PROTECTION

$\log \#+\ldots$

DIVISION OF AIR POLLUTION

FRANKFORT. KENTUCKY 40601

INDIRECT HEAT EXOHANGER

Polnt of Emission Number 12.-VA-03

1. A completed form (No. APC 110A) shall be wbrittod for eoch individual unit. The following types of units are exempted from this pospion of the application:

A Indirect heot exchangers used sololy for heoting rosidential buildings not exceoding a total of six opartment units;

B. Now installotions with a copacity of less then 1 million BTU por hour input;

C. New installotions using nofural or liquified potroloum gos, including those having distillate fuel oil os standby fuel with a copocity of loss than 50 million BTU por hour input;

D. Marine installotions and locomorives;

E. Internal combustion engines and vohicles used for transportation of passengers or freight.

If your indirect heat exchanger is in one of the above categories please check that carego and complete only items $7,8,9$.

Now installations are those for which construction commenced ofter April 9, 1972

2. Type of Unlt li-12701 CSD Heater

A. Menufacturer's Nomo

TBD
B. Manufocturor's Hodal Number
TBD
C Date Installed

NA

3. Rotod Copactiy-Inpur (BTU/Mr.) 128 million

4. Type of Combustion Unit (Cocl) With fly ash roinjection Without fly ash roinjection

NA
A. Pulverized
Dry Bottom
Wot Botiom
C. Stoker-fired
Sproader Stoker
Other Stoker
B. Cycione
D. Hand-fired
E. Other (Specify)

5. Type of Combustion Unit (oil) Not yet determined.

A. Tongentially-fired

B. Horizonially-fired

6. Type of Combustion Unit (Wood) NA

With fly ash roinjection

Without By osh roinjection
A Pile
8. Thin Bod
C. Crelonic 
7. Typo and Quentity of Fuol (List bath primary and stancby):

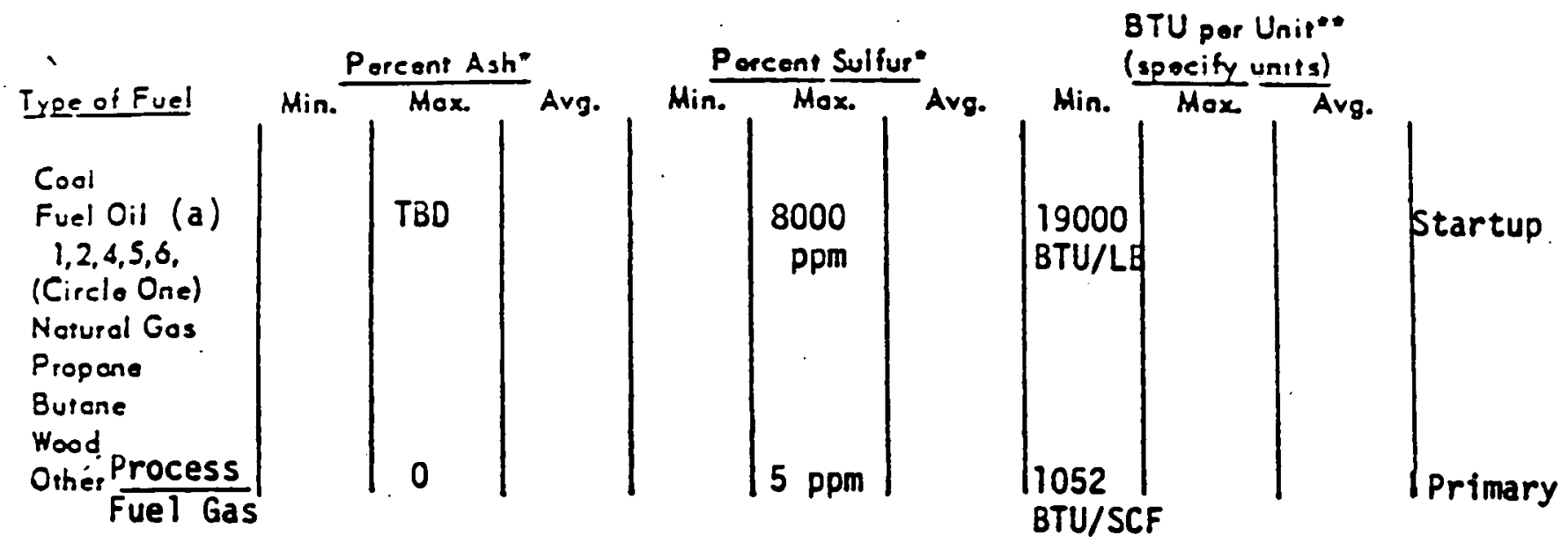

Giy.

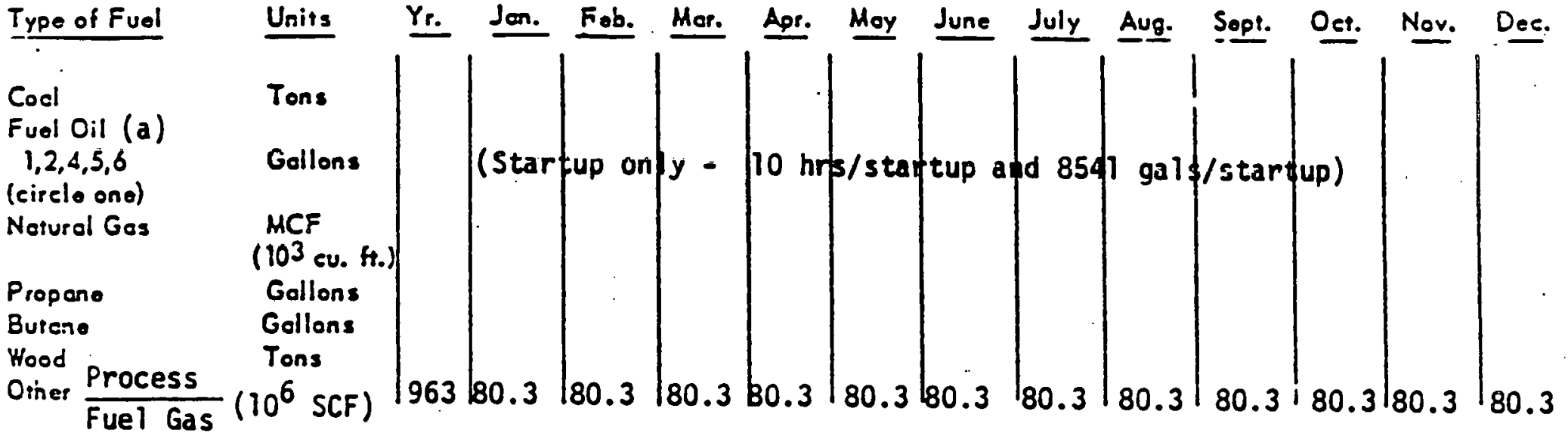

8. Fuol Sourco

\section{Process}

9. Normal Oporating Sehodula: 24 Hours per doy (330 days/yr)

As racoived bosis (Proximete anolysis for ash, ultimate onalysis for sulfur) Higher hooring valuo.

(a) Process Fuel 0 il 
10. Purpose (If multipurposo, describe poreant in sech use cotesony)

Space Heat

Process Hoot $100 \%$

Powor

11. Type of Conirol Equipment

\section{Control Efficioncy \\ Particulates $\mathrm{SO}_{2}$ Other (Spocify)}

\section{Basis of Estimato}

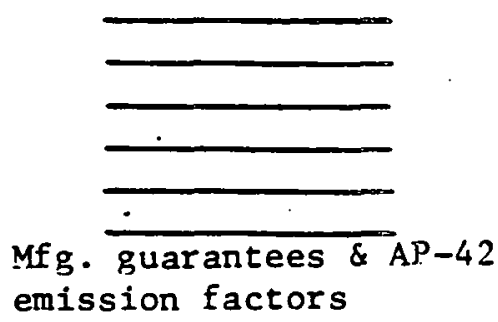

(32.) Burner Design \& Heater Operation

Eloctrostatic Procipitator Cyclōne Multiple Cyclone

Wes Serubber Sorrling Chanber Other (Spocity)
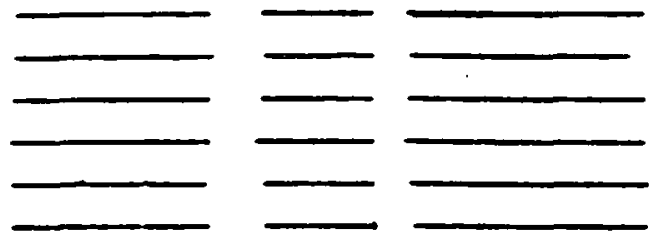
A. Outlot tomperature
400 - $F$
B. Outiot volocity
C. Hoight 150 50 $\mathrm{ft} / \mathrm{sec}$

D. Inside diameter (outlot) 52 inches:

** E. Number of sompling ports providod Not yet available

** F. Noxsost di stence from sompling port downstroan to stock outlot, bend or obstruetion Not yet available foot

G. Noarsest distanco from sompling porr upstruen to bend or obstruetion Not yet available foet

H. List other sources vented so this stock (See Item 14)

13 Combustion oir: Notural droft Inducod "Balanced Draft"

Forced prossuro Bbesain.

Exeess air (total air supplied in exeess of theorotical air required) 5 $\%$

14. Doscribe fual tronsport, storoge mothods and rolated dust control mocesures.

This unit will be used both as process heater and as an incinerator. Refer to the ppropria segments of Section 8.0 "BACT Proposals" for decriptions and operations.

15. Deseribe fly ash (or other collectod air contominenta) disposol, mensportation mothods and rolotod dust conirol meosures

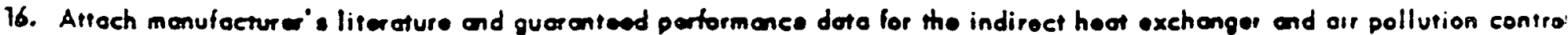
-quipment. Inelude information concerning fuol input, burners and combustion chamber dimonsions.

Information not available yet but will be provided as soon as available.

* Sampling ports and access equipment will be provided to comply with Kentucky Air Pollutiom Control Regulations 401 KAR 50:45 and 401 KAR 50:015 
OEPARTAENT FOR

NATURAL RESOURCES ANO

ENVIRONMENTAL PROTECT ION

$\log \#-\ldots$

OI VISION OF AIR POLLUTION

FRANK FORT, KENTUCKY 40601

\section{INDIRECT HEAT EXEHANGER}

Polnt of Emission Number 12-VA-04

1. A comples od form (No. APC 110 A) shall bo wbmittad for each individuol unit. The following irpes of units are oxempied from this portion of the epplication:

A Indirect heot exchangers used solely for heating residential buildings not exceoding a total of siz coprtment units;

8. Now installations with a capocity of lesa then 1 million BTU por hour input;

C. Now installations using notural or liquified potroleum gos, including those having distillate fuel gil os stondby fuel with a copocity of lass than 50 million BTU por hour inpur;

D. Marine installetions and locomotives;

E. Infernol combustion engines and vohicles used for trensportation of passengers or froight.

If your indirect heat exchanger is in one of the above categories please check that carego: and complete only items $7,8,9$.

Now installations are those for which construction commenced oftor April 9, 1972.

2. Type of Unit $\mathrm{H}-12501$ Hot Oil Heater

A. Menufacturer's Nome TBD

B. Manufacturor's Hodel Number TBD

C Dote Installed

NA

3. Rotod Copactiy-Inpur (BTUMr.) 50 million

4. Type of Combustion Unit (Cod) With fly esh roinjection Wishout fly ash roinjection

NA
A. Pulverized
Dry Bottom
Wot Botrom
C. Stoker-fired
Sproader Stoker
Othor Stoker
B. Cyclone
D. Hond-fired
E. Other (Specify)

5. Typo of Combustion Unit (oil) Not yet determined.
A Tangentially-fired
B. Horizontally-fired

6. Type of Combustion Unit (Wood) NA

With fly osh roinjoction

Without fly osh reinlection
A. Plle
8. Thin Bed
C. Cyclonic 
7. Typo and Quonsity of Fuol (List both primory and standby):

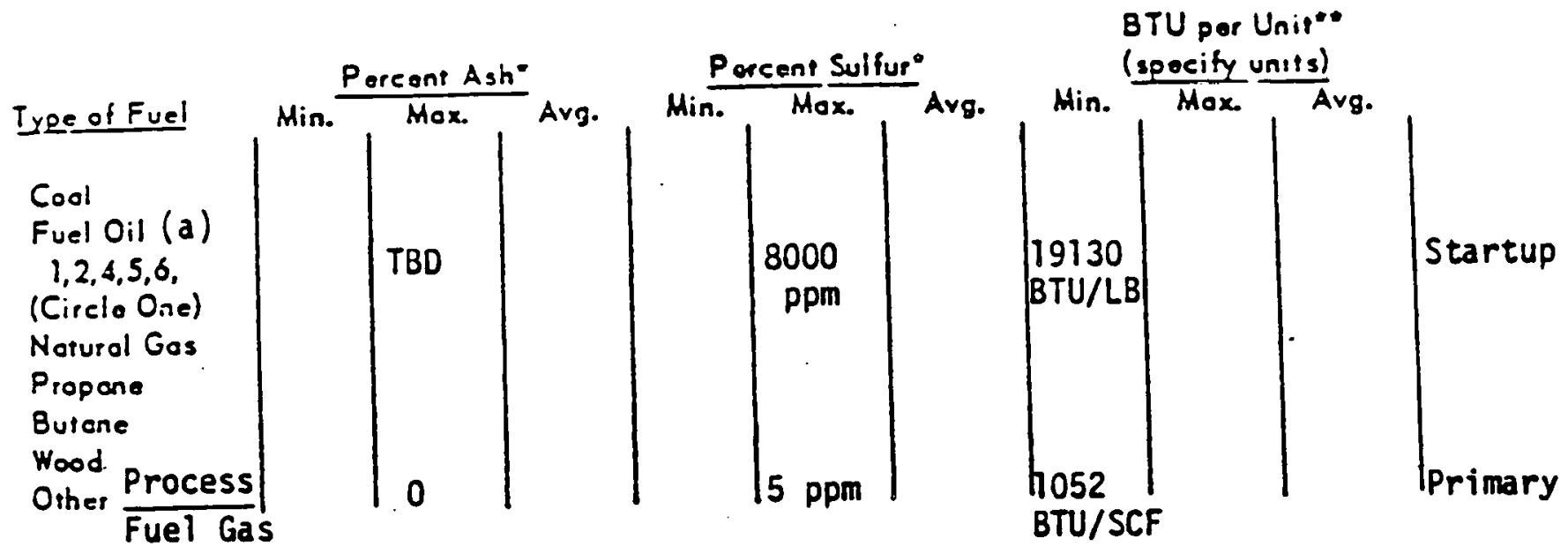

Type of Fuol Units Yr. Jan. Fob. Mar. Apr. Moy June July Aug. Sopt. Oet. Nov. Dec.

Cocl

Fual Oil (a)

$1,2,4,5,6$

(cirelo ono)

Nolural Gas

Propano

Butene

Wood Butene
Wood Process
Other Fuel Gas
Funs

380

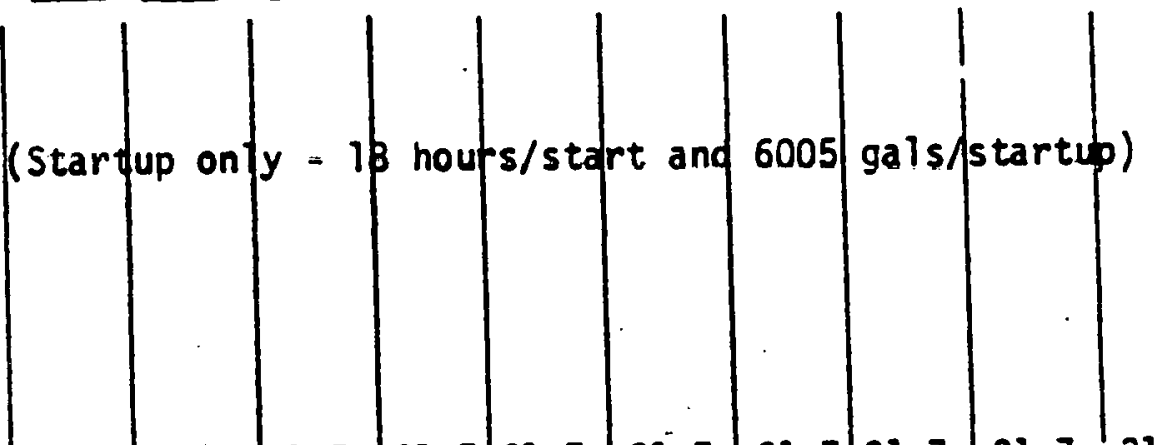

8. Fuol Sourco

Process

9. Normal Oporoting Sehodula: Mours por doy ( 330 days/yr)

- As rocoived bosiz (Proximate ondysis for ash, ultimato onalysis for sulfur)

- Migher hooting valuo.

(a) Process Fuel 0 il 
10. Purposo (If multipurpose, doscribe pereant in socti use cotegory)

Space Heat

Procoss Hoot $100 \%$

Dowor

11. Typo of Control Equipment

$$
\text { Porticulates } \frac{\text { Control Efficioncy }}{\mathrm{SO}_{2} \text { Other (Specily) }}
$$

Electrostotic Precipitotor

\section{Cyelóne}

Multiple Cycione

Wot Serubber

Sottling Chamber

Other (Spocity)

(3) Surner Design and Heater Operation

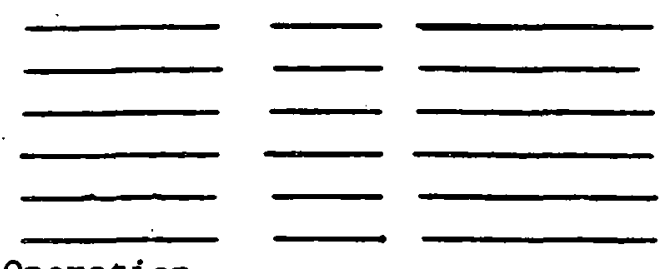
A. Outlot 1omperoture
400
'F
B. Outlet velocity
50
$\mathrm{ft} / \mathrm{soc}$
C. Hoight
150
foot

D. Insido dianoter (ouflor)

33

inches

* E. Number of sampling ports providod Not yet available

** F. Neorast distonce from sompling port downstrean to stock outlot, bend or obstruction. Not yet availablefoet

** G. Noarsst distance from sompling port upstroan to bend or obstruction Not yet available foet

H. List other soureas ventod to this stock

13 Combustion air: Notural draft Indueed

Foreod pressure lbelsqin.

Excess air (total air suppliad in axeess of theorotical air required) "Balanced Draft"

Mfg. guarantees and AP-42 emission factors

14. Describe fuel tronsport, storoge mothods and related dust control moasures.

This unit will be used as a process heater. Refer to the appropriate segment of Section 8.0 "BACT Proposals" for description and operation.

15. Describe fly ash (or other collected air conteninents) disposal, transportation mothods and roloted dust control moosures.

NA

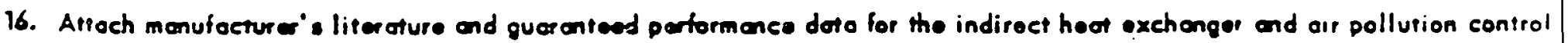
-quipmons. Include informotion concorning fuol input, bumers and combustion chomber dimansions.

Information not yet avaikable, however will be submitted as soon as available.

* Sampling ports and access equipment will be provided to comply with Kentucky Air Pollution Control Regulations 401 KAR 50:45 and 401 KAR 50:015. 
1. A completod form (No. APC $110 A$ ) shall be wbraitlod for each individual unit. The following types of units are oxemptod from this poreion of the application:

A Indirect hoat axchangers used wolely for heoting rosidential buildings not exceoding o total of six oporiment unirs;

8. Now installetions with o capocity of less than 1 million BTU por hour input;

C. Now instollotions using natural or liquified potroleum gas, including thoso hoving distillate fuel ail os standby fual with o capacity of loss than 50 million BTU por hour input;

D. Marino installations and locomotives;

E. Intopnol combustion enginos and vohicles usod for tron sportation of passongers or froight.

If your indirect heat exchanger is in one of the above categories please check that catego: and compleze only itcms $7,8,9$.

New installations ase those for which construction commenced fiter Apell 9, 1972

2 Type of Unit Coking Heater $\mathrm{H}-13101$

A Menufocturer's Nome Not yet available

B. Manufacturor's Modal Number Not yet available Dore Installod Not applicable to new instal

3. Rotod Copoctiy-Input (BTU/Hr.) $46 \times 10^{6}$

4. Typo of Combustion Unit (Cod) Wish Hly osh soinjection Manufacturer's capacity rating will be furnished when available.

A. Pulvorized

Dry.Bottom

Wot Bortom

8. Cycione

\section{Withous fly ash roinjection — NA}

5. Typo of Combustion Unit (oil) Not yet determined.

A Tangentially-firad

B. Horizontally-fired

6. Type of Combustion Unit (Wood)

NA

With fly esh roinicetion

Without fly ash reiniection
A Pile
8. Thin Bod
C. Crelonie 
Type and Quentity of Fual (List both primary and standby):

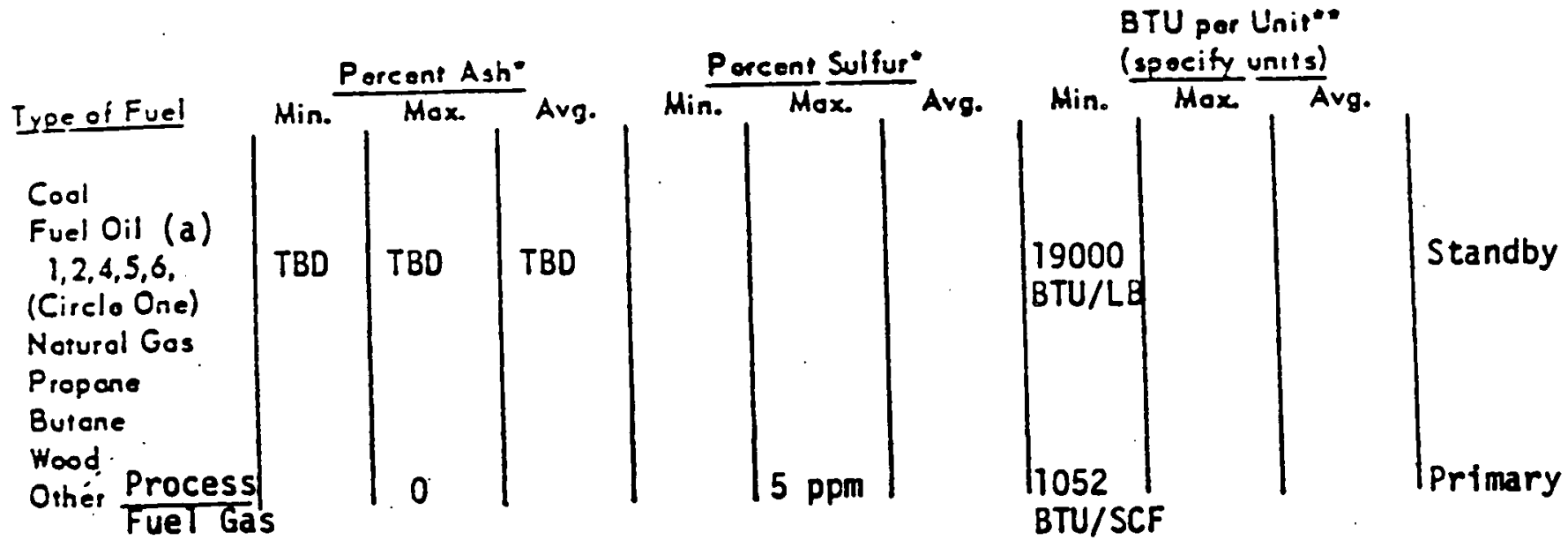

C.

Type of Fuol Units Yr. Jan. Fob. Mor. Apr. May June July Aug. Sopt. Oer. Nor. Dec.

Coal

Fuel Oil (a)

$1,2,4,5,6$

(circle ono)

Notural Gas

Propano

Butene

Hood

Other Process Fuel Gas
Tons

Gollons

MCF

$\left(10^{3} \mathrm{cu} . \mathrm{ft}.\right)$

Gallons

Gollons

Tons

C.y.

8. Fual Sourco

All fuel used during normal operation is produced within the facility.

9. Normal Oporoting Schodula:

47.0

Wooks por yoor,

7

Coys por woak,

24

Hours per doy

- As rocoived basiz (Proximate analysis for ash, ultimate onalysis for sulfue)

- Higher hooring valuo.

(a) Process Fuel 0 il 
10. Purpose (If multipurpose, describe porcent in each use catopary)

Spoce Heot

Process Heat

Nowor

11. Typa of Control Equipment

$$
\text { Particulatos } \frac{\text { Control Efficioney }}{\mathrm{SO}_{2} \text { Other (Specify) }}
$$

Eloctrostatic Procipitatar

Cyelone Mulriple Cyclone

War Scrubbor Sonting Chamber

(a) Other (Spocify)
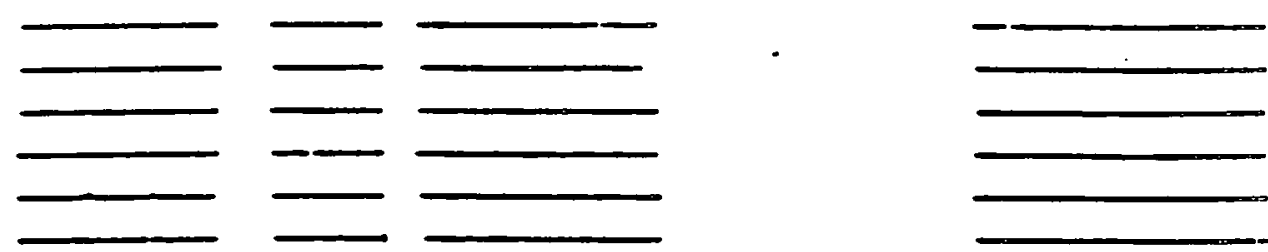

12. (a) Sock Heater Operation
A. Outlet remperature
350 P
B. Outlet velocity 50 ft/ sec
C. Hoight 150 foot

D. Inside diameter (ouples) TBD inches

E. Number of sompling ports providod Not yet ayailable

F. Noarest distance from sompling port downstroen to steck outlot, bend or obstruetion. Not yet available foop

G. Noceses di stence from sompling port upstrean to bend or obstruction Not yet available set

H. Lis: other sources vented to this steck

13 Combustion air:

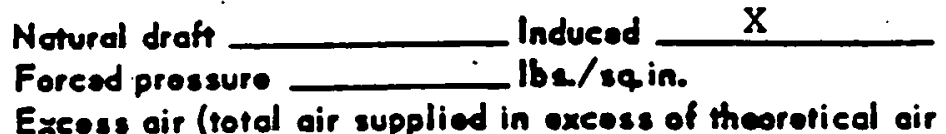
Ibe/sqin.

Exeess air (total air supplied in exeess of theoretical oir required)

20.0 $\%$

14. Doscribe fuel traneport, storege methods and releted dust control measures.

See Section 4.2 Area Process Descriptions

15. Doscribe ily ash (or other collected air conteninents) disposel, rrensportation methods ond rolated dust control measure Buming fuel gas will produce minimal fly ash.

16. Alfech menufocture's a liferature and guerantood pertormance dota for the indirect heat exchanger and olr pollution contr equipment. Ireludo information concarning fual input, bumers and combustion chamber dimensions.

Not yet available, but will be provided as soon as it is available. 
NATURAL RESCURCES AND

ENYIRONAENTAL PROTECTION

OI VISION OF AIR POLLUTION

FRANX FORT. KENTUCXY 40601

\section{INDIRECT HEAT EXCHANGER}

$\log \#-\ldots$

Point of Emission Number 13-VA-10

1. A complefod form (No. APC 110 A) shall bo submitted for each individual unit. The following types of units are exompled from this porrion of the application:

A. Indirect hoot oxchangers usod sololy for heoting residential buildings not excooding a totul of six coperment units;

B. Now installations with a capacity of less than 1 million BTU por hour input;

C. Now instollations using notural or liquified potroloum gos, including thoso hoving distillate fuel ail as standby fual with a capacity of lass than 50 million BTU per hour input;

D. Marire installations and locomotives;

E. Intornol combuation engines and vohicles used for ironsportotion of possongers or froight.

If your indirect heat exchanger is in one of the above categories please check that. categ aid complete only items $7,8,9$.

Now installotions cre those for which construetion commencod oftor April 9, 1972

2 Typo of Unif Hydrocracker Feed Heating SustemA. Menufectur or 's Nomo Not yet ayajlable

B. Monufacturer's Modol Number Not yet available C Dote Instollod Not applicable to ners instale

3. Ratod Cepactiy-Inpur (BTUMr.) $27 \times 10^{6}$

4. Typo of Ccmbustion Unit (Cocl) Hith fly osh soinjection Without fly ash rainiection

NA
A Pulverized
C. Stozer-fired
Dry Botiom
Srooder Stoker
Wot Botrom
Other Sroker
B. Cycione
D. Hond-fired
E. Orher (Specify)

5. Typo of Combustion Unit (oil) Not yet determined.
A. Tangentially-firod
B. Hori sontally-fired

6. Type of Combustion Unit (Wood) NA

With fly esh poinjection

Without fly agh reiniection
A Pile
B. Thin Z॰d
C. Cyclonic 
- Type and Quantity of Fual (Li st both primory and standby):

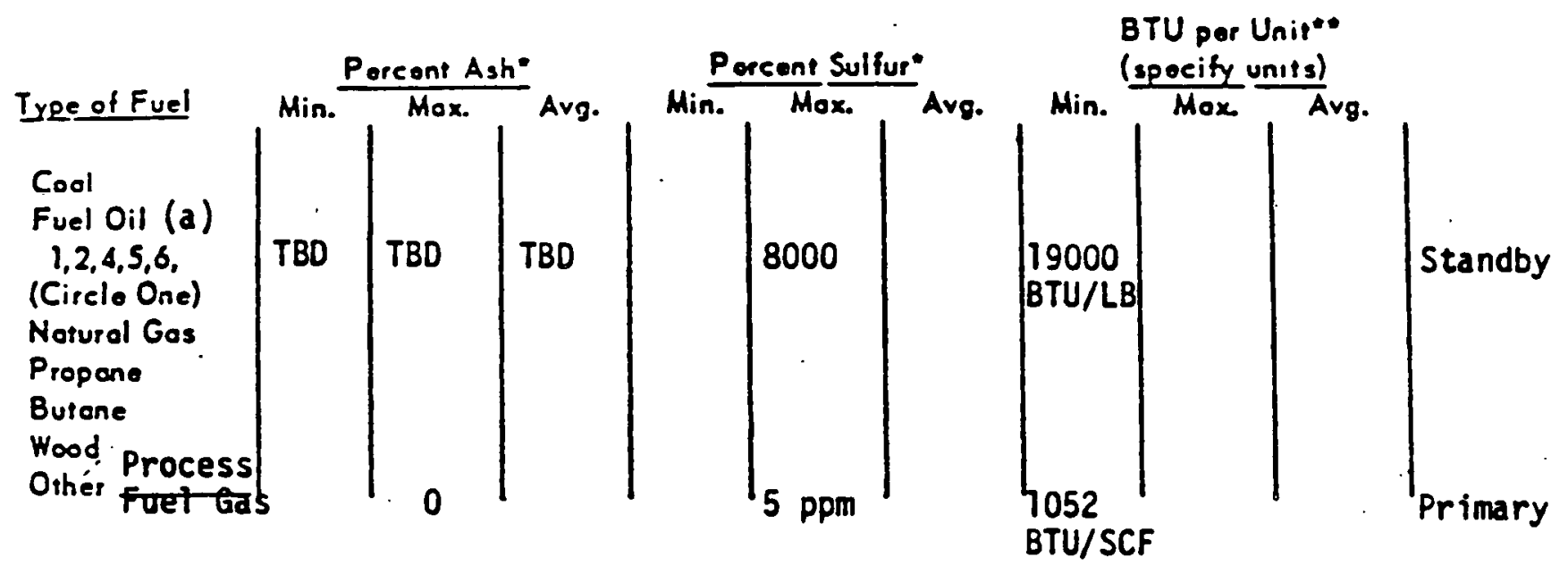

Qty.

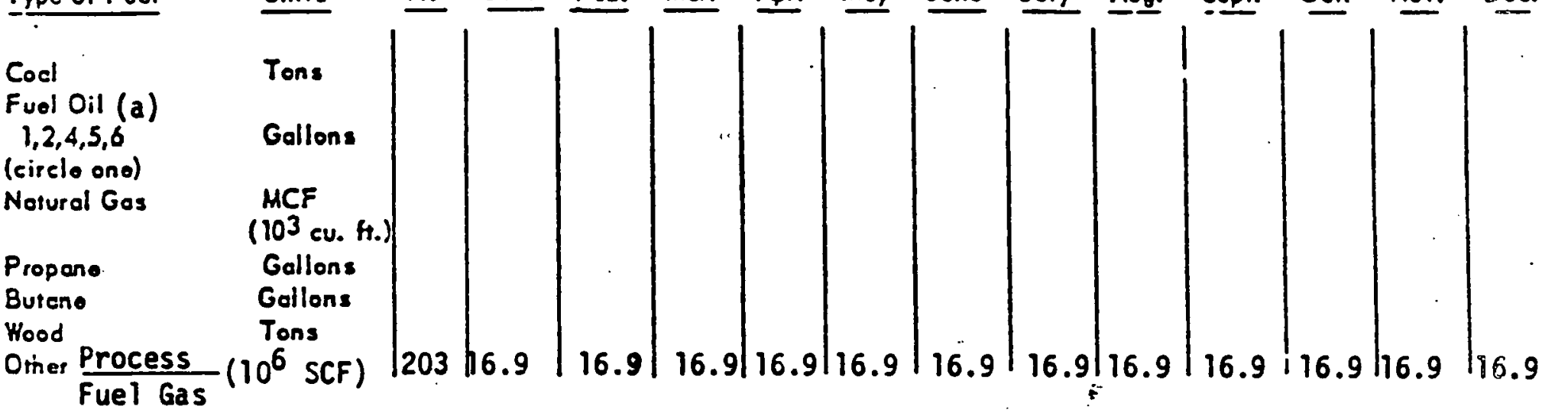

8. Fuol Source All fuel used during normal operation is produced within the facility.

9. Normal Oporeting Schodulo:

47.0 Wooks per yoor, 7 Coys por wook. Hours por doy

- As recoived bosia (Proxímete onolysis for ash, ultimote onalysis for sulfur)

- Highor hooting voluo.

(a) Process Fuel 0 il 
10. Purpose (If multipurpose, doscribe percant in ecch use cotegary)

Space Heot

Process Hoot

Dower

11. Typo of Control Equipment

$$
\text { Particulctos } \frac{\text { Control Efficimey }}{\mathrm{SO}_{2} \text { Other (Spocify) }}
$$

Bosis of Estimeso

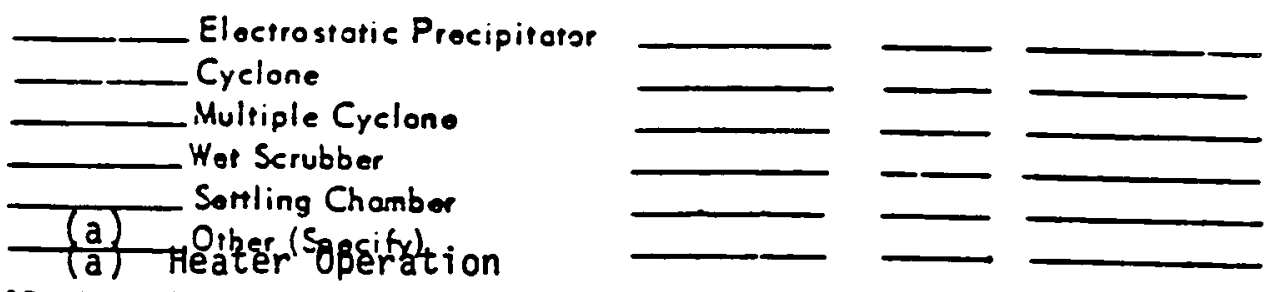

12. Srock (See APC-110 A form for Hydrocracker Feed Heating System Stack data)
A. Outlet iomporature of
B. Outlet velocity
C. Height $\mathrm{fi} / \mathrm{sec}$
D. Insido diameter (outlot)
E. Number of sempling ports provided
F. Neorest distare from sompling port downstroon to stock outlot, bend or obstruction
G. Noarost distance from sampling port upstrean to bend of obstruction
H. Lis: othor souress rantod to this stack incties

13 Combustion oir: Notural drof TBD

Foread prossure Induesd

Excoss air (rotal aip supplied in excess of theorofical air required) $10 . C-15.0$ SeQP foet

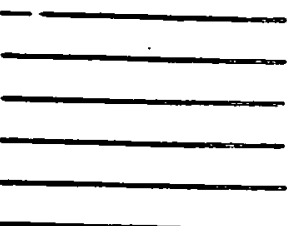




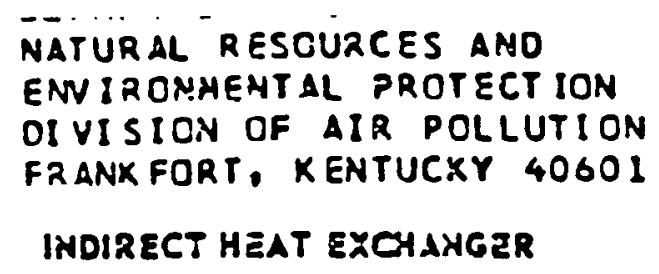

Log

ENVIRONAEHTAL PROTECTION

$--$

Point of Emlision Numbor 13-VA-10

1. A comple:ed form (No. APC $\| O A$ ) shall bo submittod for oech individual unit. The following ippos of units are exempiod from this portion of the epplicetion:

A Indirect hoot oxchengers used solely for heoting residential buildings not exceoding a total of six oportment units;

B. Now installations with o copocity of lass then 1 million BTU por hour inpul;

C. Now instollotions using notural or liquified potroleum gas, including those hoving distillope fuel ail as standby fual with a capacity of lass than 50 million BTU per hour input;

D. Marine installations and locomotivos;

E. Intornal combustion ongines and vohiclos used for tronsportation of possongers or froight.

If your indirect hejt exchanger is in one of the above categories please check that categ ard complite only itoms $7,8,9$.

Now installations are tho se for which construction commencod oftor April 9, 1972

2. Typo of Unit Vacinm 136 her Heater - A Honufcetur or's Nomo Not yet available

B. Monufacturer's Modol Number Not yet available $C$ Dote Installod $\frac{\text { Not applicable to new }}{\text { Installations. }}$

3. Rotod Cepoctiy-input (BTUMr.) $1.0 \times 10^{6}$

4. Typo of Cembustion Unit (Codl) With fly osh roiniection Without tly osh roinjection

NA
A. Pulverized
Dry Estrom
Wot Botiom
C. Stoxer-firod
Srrooder Stoker
Other Stoker
B. Cycione
D. Hand-fired
E. Orher (Spocify)

5. Typo of Combustion Unir (oil) Not yet determined.
A. Tangentially-fired

B. Horizontally-firod

6. Type ol Cembustion Unir (Hood) NA

With fly osh soinjoction

Without fly asin rainlection
A. Pil.
8. Thin Zod
C. Cyclenic 
Type and Quontity of Fuol (List both primary and stendby):

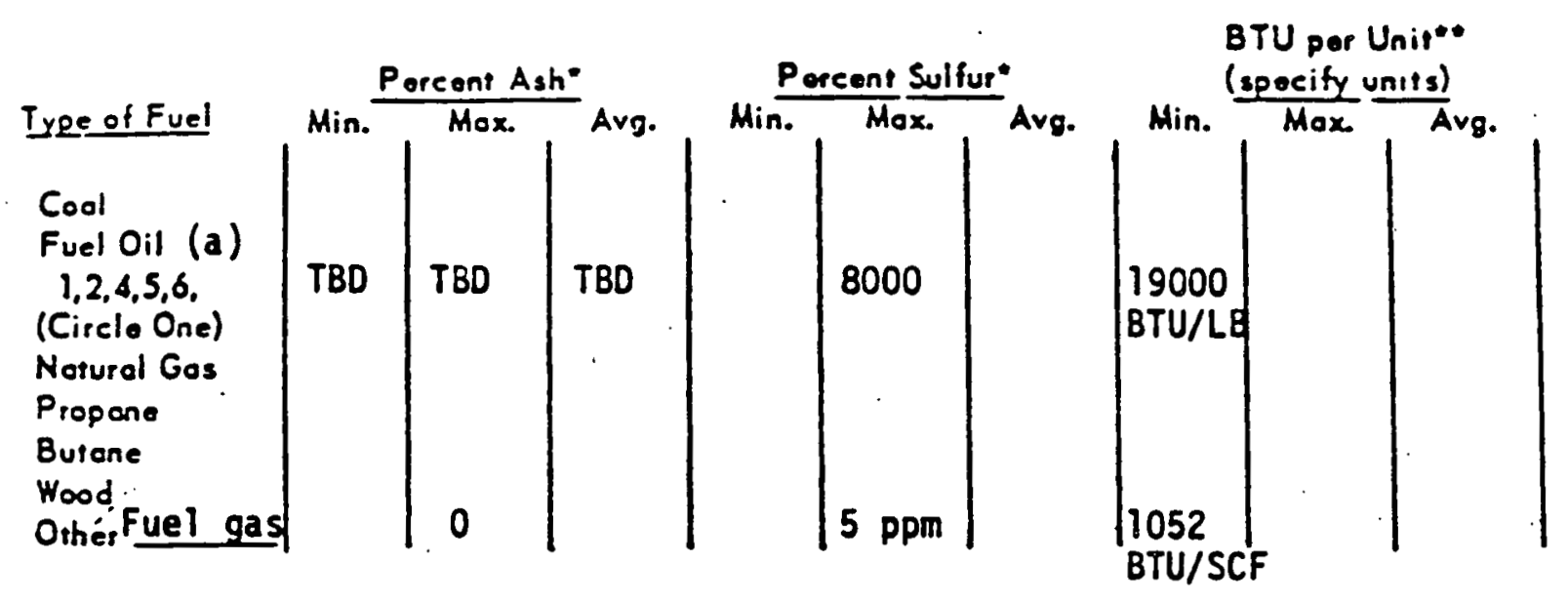

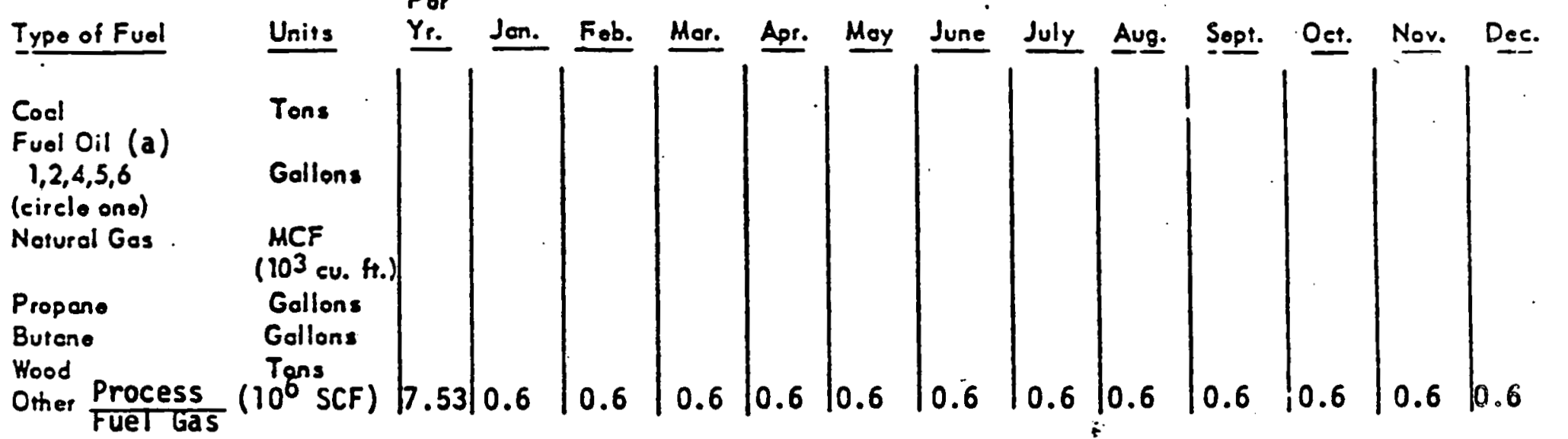

8. Fuol Sourco All fuel used during normal operation is produced within the facility.

9. Normol Oporating Sehodulo:
47.0
Wooks per yoar,
7 Coys por work.
24. Hours por doy

- As rocoived bosis (Proximate onolysis for ash, ultimato onalysis for sulfur)

- Higher hooting voluo.

(a) Process Fuel 0 il 
10. Purposo (If multipurposo, doscribe poreant in eoch use cotegory)

Space Heot

Process Heat . $\mathrm{X}$

Power

11. Typo of Control Equipment

$$
\text { Particuleter } \frac{\text { Control Efficioney }}{\mathrm{SO}_{2} \text { Other (Specify) }}
$$

Bosis of Extimate

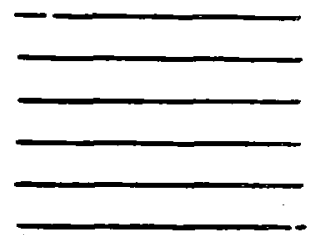

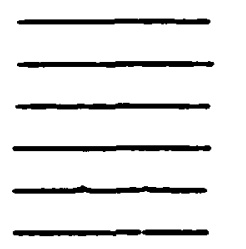
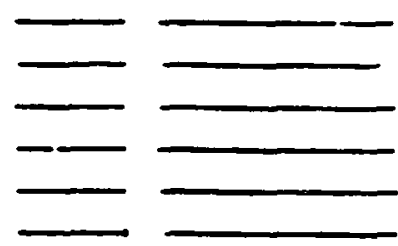

12. (a) Siock

Eloctrostatic Procipitator Cyclone Multiple Cyclone

Wat Scrubber Sattling Chamber (a) Oiher (Spocify)
F. Noopost distence from sompling port downstroem to stock outlot, bend or obstruetion not yet available

A. Outlot romporoture $\frac{660}{50}$ Outlet velocity $\mathrm{fo} / \mathrm{sec}$

A. Outlot remperoture $\frac{660}{50}$ 'F
B. Outlet velocity

C. Height 150 foos

D. Inside diamotor (outlot) TBD inches

E. Number of sompling ports providod not yet available.

G. Noarest distance from sompling port upstrsan to bend or obstruesion not yet available fsot

H. Lis: other sourees vented to this stock Vagum Towar Heater

13 Combustion oir: Notural deoft Induesd

TBD

Forcad prosusure ibs/sain.

Excoss air (topal air supplied in excess of theoratical air required)

$10.0-15.0$ 星

\section{See Section 4.2 Area Process Descriptions}

15. Describe fly ash (or other collocted air conteninents) disposal, transport otion methods and rolotod dust control measus Burning Fuel Gas will produce minimal fly ash.

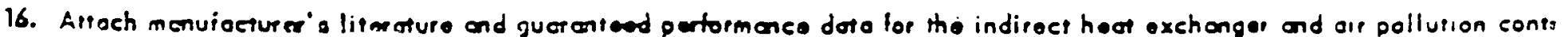
equipenumt. Include irformotion concarning fual inaut, bumers and combustion chomber dimensions. Not yet available, but will be provided as soon as it is available. 
DEPARTAENT FOR

NATURAL RESOURCES AND

ENVIRONMENTAL PROTECT ION

$\log \#-\ldots$

DIVISION OF AIR POLLUTION

FRANK FORT. KENTUCKY 40601

INDIRECT HEAT EXOHANGER

15-VA-02

1. A completod form (No. APC 110 A) sholl bo wbmitted for eech individual unit. The following types of unsts are oxempted from this porston of the application:

A Indiroct hoor oxchengers usod sololy for heoting rosidential buildings not excooding a fotal of six coportment units;

B. Now installations with a copocity of lesa then 1 million BTU por hour input;

C. Now installations using notural or liquified potroloum gas, including those having distillato fual oil os standby fuel with a capacity of less than 50 million BTU per hour input;.

D. Marine installations and locomotives;

E. Internal combustion ongines and vohiclos usod for trensportation of passengers or froight.

If your indirect heat exchanger is in one of the above categories please check that categor and complete only items $7,8,9$.

Now installotions aro thoso for which construction commoneod oftor Apell 9, 1972

2 Typo of Unit Gasifier Preheater H-0305__. A Monufacturor's Nome

B. Monufocturor's Hodel Number

TBO

C Doto Installed

NA

Desion

3. Rorod Copactiy-Input (STU/Hr.)

$40.3 \times 10^{6}$

4. Type of Combustion Unit (Cod) With fly ash roinioction

Wishout fly ash rainjection

NA
A. Pulverized
Dry Botrom
C. Stoker-fired
Wot Botiom
Sroador Stoker
Other Stoker
B. Cyelone
D. Hend-fired
E. Othor (Specify)

5. Type of Combustion Unit (oil) TBD

A. Tangentiolly-firod

B. Horizontally-firod

6. Type of Combustion Unir (Wood) NA

With fly osh reinioction

Wistout Ay ash roinjection
A. Pllo
B. Thin Bod
C. Cyctorie 
- Typo and Quantiry of Fuol (List both primary and standby):
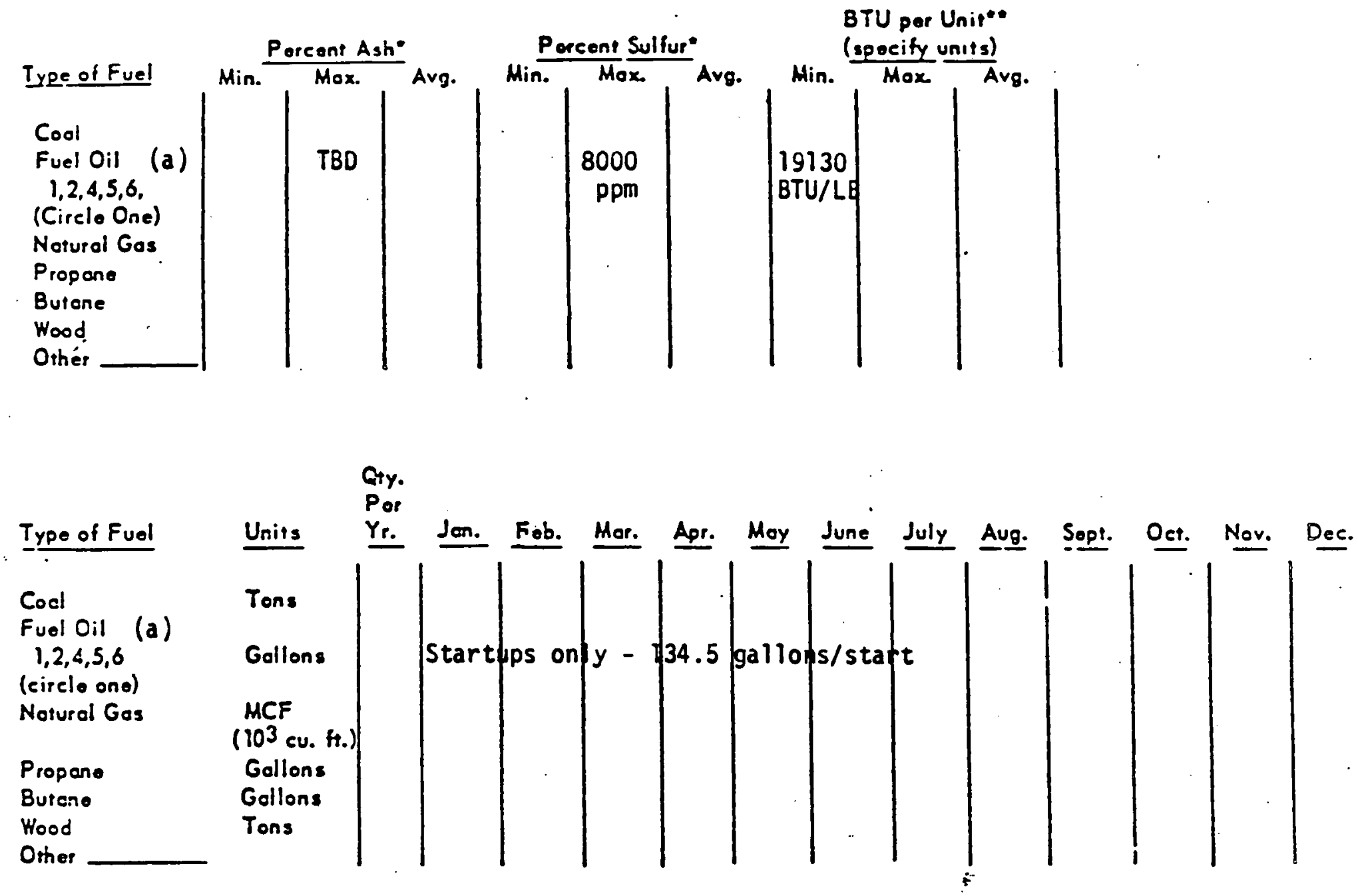

8. Fual Source

Process derived fuel

9. Normol Oporoting Schodula: Startups only

Wook s per yoar, Coys poe wook. Hours por doy

- As recoived basiz (Proximete onolysis for osh, vitimato onalysis for sulfur)

- Higher hooring valuo.

(a) Frocess fuel 0 il 
10. Purposo (If multipurpose, doscribe percent in each use cotogery)

Space Heot

Process Hoot -

Power

11. Typo of Control Equipment

$$
\text { Particulatos } \frac{\text { Control Effieloncy }}{\mathrm{SO}_{2} \text { Othor (Spocify) }}
$$

\section{Bayis of Estimate}

Elocirostotic Procipirator Cycione

Multiple Cyclono

Wor Scrubbor

Sottling Chanber

(a) Other (Spocify)

(a) Heater Operation
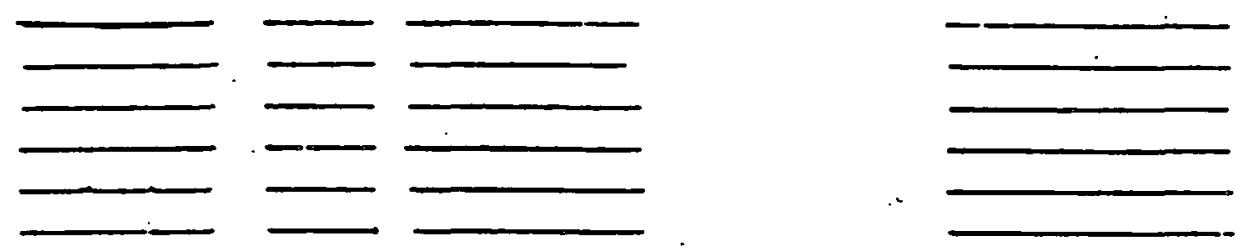

12. Slock
A. Outler tomperature 'F
B. Outlot velocity
C. Hoight $f 8 / \sec$
D. Inside diamster (outlet)
E. Number of sompling ports providod
F. Noorost distanco from sampling port downstroan to stcek outlot, bond or obstruction
G. Nearost distanco from sampling port upstroem to bend or obstruction
H. List other sourcos vantod to this stock inchss

13 Combustion air: Notural draft Induead

Foresd prossure 162/sqin.

Excess air (total air supplied in oxcess of theorotical air requirod)

14. Describe fuel transport, storage methods and roleted dust control moasures.

\section{See Section 4.2 Area Process Description.}

15. Doscribe fly ash (or othor colloctod air contcrainanta) diesosel, tranepartation mathods and relotod dust conirol moosure

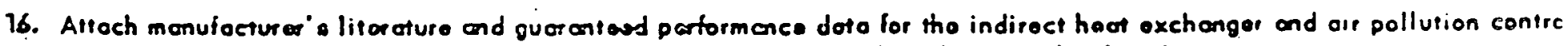
-quipmens. Ineluds informotion concorning tuol input, bumors and combustion chember dimensions.

Not yet available, but will be provided as soon as possible. 
DEPARTMENT FOR

NATURAL RESOURCES ANO

ENVIRONMENTAL PROTECTION

DI YISION OF AIR POLLUTION

FRANK FORT. KENTUCKY 40601 $\log \# \ldots-\ldots$

\section{INDIRECT HEAT EXOHANGER}

Point of Emlssion Number 15-VA-03

1. A completed form (No. APC I10A) shall be submitted for oach individual unit. The following ippes of units are oxemplod from this portion of the applicetion:

A Indiroct heot oxchengers used sololy for heoting residential buildings not exceoding o topol of six cortmont units;

B. Now instolletions with a copocity of less than 1 million BTU per hour input;

C. Now installotions using natural or liquified potroloum ges, including thoso hoving distillote fuel oil os standby fual with a eopocity of lass thon 50 million BTU par hour input;.

D. Morine installations and locomotives;

E. Intornal combustion ongines and vohielos usod for trensportation of possongers or froight.

If your indirect heat exchanger is in one of the above categories please check that casego and complete only items $7,8,9$.

Now installations aro those for whlch construction commoncod afior April 9, 1972

2. Type of Unit Shift Startup Heater H-1503_A Menufoeturer's Nome

B. Manufocturor' Hodal Number TBD

C Doto Installod

NA

3. Rotod Copoctiy-Input (STU/Hr.) $29.2 \times 10^{6}$

4. Typo of Combustion Unit (Coel) With fly ash roinjection Wishout fly osh reinjoction

NA
A. Pulvorized
Ory Bortom
Wot Boffom

B. Cyclone

C. Stokor-firod Sproador Stoker Other Stoker

D. Hond-flred

E. Othor (Specify)

5. Typo of Combustion Unis (oil)

TBD

A Tangentially-firod

B. Horizontally-firod

6. Type of Combustion Unit (Wooo')

NA

With fly osh reinioction

Without fly abh roinjection
A Pilo
B. Thin Bod
C. Cyctonic 
Typo and Quantiry of Fuol (List both primary and standby):
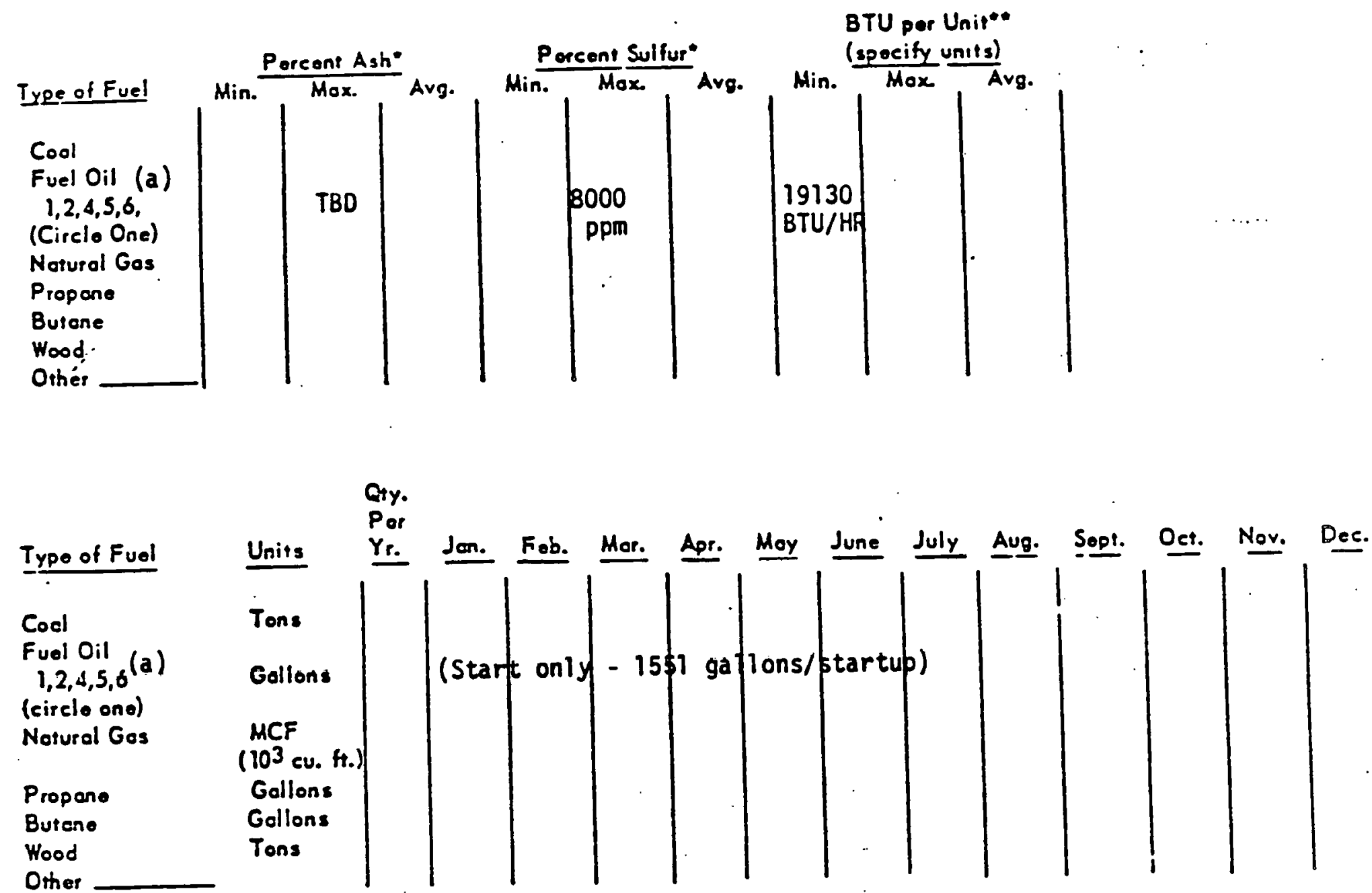

8. Fuol Source

Process derived fuel oil

9. Normol Oporating Schodula: Startups Onily

Wooks per yoor,

Coys por wook.

Hours per doy

- As racoived bosis (Proximate andysis for ash, ulsimate onalysis for sulfur)

-. Higher hooting volua.

(a) Process Fuel 0 il 
10. Purposo (If multipurpose, doseribo percent in wach use cotogery)

Soace Heat

Procoss Hoot

Powor

11. Typo of Control Equipment

$$
\text { Porticulatos } \frac{\text { Control Efficioney }}{\mathrm{SO}_{2} \text { Other (Spocify) }}
$$

Basis of Estimato

Eloctrostatic Procipitator Cycione

Multiple Cyclono

Wot Serubber

Sottling Chanbor

(a) Other (Spocify)

(a) Heater Operation

12. Srock TBD
A. Outlot tomporature
B. Outlot velocity
C. Hoight
D. Insido diomstor (oustor)
D. Nisido diamotar (oullos)
of
$\mathrm{ft} / \mathrm{soc}$ inchos

E. Numbor of somplino ports providod

F. Noor ost distoneo from sompling port downstroen to stock outlot, bond or obstruetion

G. Noasost distanco from sompling port upstraem to bend or abstruction

H. Lis: othor sourcos vantod to this stack

13. Combustion air: Notural draft TBD

Forcod prossuro Inducod Bbe/sqin.

Exesss air (sotal air supplied in oxcess of theorotical air roquirad) $\%$

14. Doscribe fuel traneport, storage mothods ond rolated dyst control moosures.

\section{See Section 4.2 Area Process Description}

15. Describ. ily osh (or othor collactod air conterainanta) dieposel, manspartation mothods and rolotod dust control measi

NA

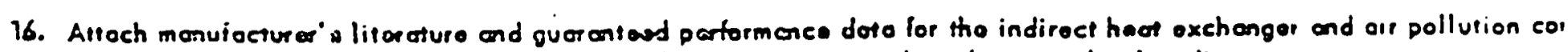
aquipmont. Includa information concorning fual input, bumors and combustion chembet dimonsions.

Not available at this time, but will be provided as soon as possible. 
DEPAR TMENT FOR
NATURAL RESOURCES AND
SNUIRONMENTAL PROTECTION
UIVISION. OF AIR POLLUTION
FRANK FORT. KENTUCKY 40601

INDIRECT HEAT EXCHANGER

Point of Emission Number $16-V A-31$

DWG No 00-16-90002 D

i. A ium;iece.t form (No. APC 110 a) shall be submitted for each individual unit. The following types of units ore exempead arom this partion of the upplicotion:
A. Indirect neat exchangers used solely for heating residential buildings not exceeding o total of six opartment units;
B. New installotions with a copocity of less than 1 million BTU per hour input;
C. Nou insta!lations using notural or liquified petroloum gas, including those having distilleic fue! ail as standby fual with a capacity of less than 50 million BTU per hour input;
D. Marine installations and locomotives;
E. Internal combustion engines and vehicles used for tron sportation of possengers or freight.

:t your indirest heat exchanger is in one of the above cotegories please check that catogory and disregard the remaining fortions of APC-110A.

New installations ore those for which construction commenced after April 9, 1972.

2. Type of Unit Oil Fired Boiler I. B-16001

B. Monufecturer's Model Number Later 1
A. Monufoutorer's Nome Iuater 1

C. Dote Instolled Later 1

¿. Rat :d Copoctiy-Input (BTU/Hr.) 260 Million Btu/Hr

. Typo of Combustion Unit (Coal) With fly osh reiniection Without fly osh rainiection
A. Fulverized
Dry Bottom
C. Stoker-fired
Sprooder Stoker
Wot Bottom
Other Stoker
B. Cyclone
D. Hand-fired
E. Other (Spocify) Oil Fired

j. Type of Combustion Unit (oil)

A. Tangentially-fired.

B. Horizontally-fired To be determined when purchased

¿. Type of Combustion Unit (Wood)

Not Applicable

With fly ash reiniection

Without fly ash reinjection
A. File _.... Not Applicable
B. Thin Bed
$\because$ Cyclonic ........

1 The boiler has not been purchased at this time. Data specific to the boiler will be supplied when purchase is complete. 
Typo and wuontity of Fuol (List soth primary and spandbv):

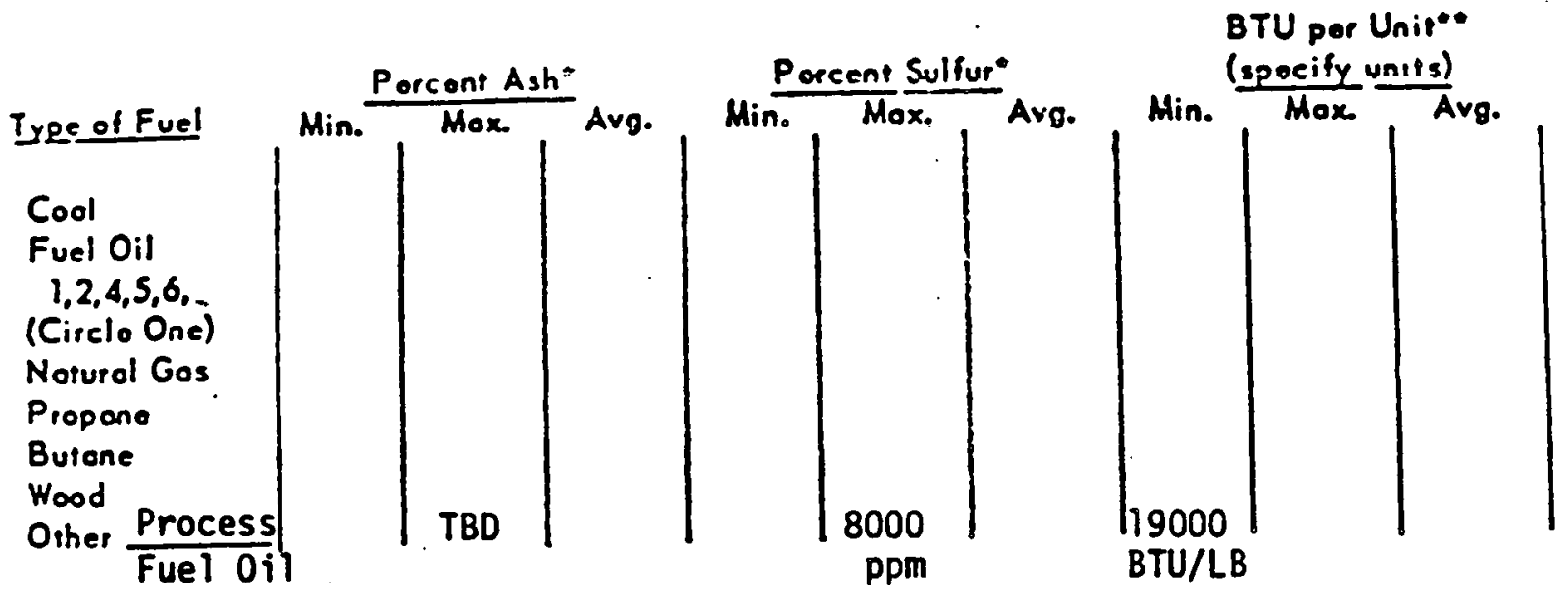

Cocl

Fual Oil

$1,2,4,5,6$

(eirelo ono)

Notural Gos

Propano

Burane

Hood Process

Units Yr. Jon. Fob. Hor. Apr. Moy June July Aug. Sopt. Oct. Nov. Dec

8. Fuol Sourcs

Tons

Gallons

MCF

(103 cu. ft.)

Gollons

Gallon:

Tons

MM Gals $10.3 \quad 86$
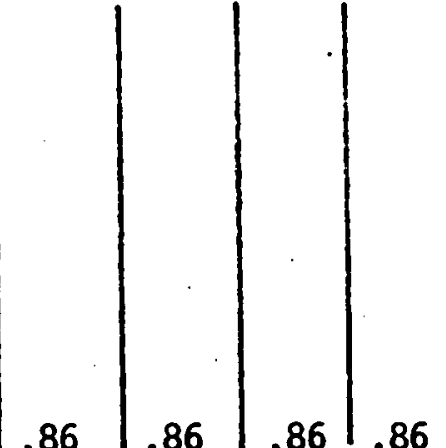

.
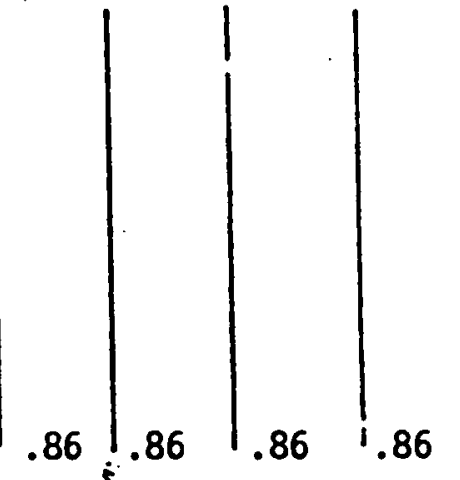

Fuel 0 il is generated in plant by SRC-I Process

9. Normul Ofne oting Schodula:

47 Wooks per yoor, 7 Coys por wuo!t. Hours por doy

75\% firing rate during normal operations

$100 \%$ firing rate during startups

- As rocoives bosiz (Proximate ondysis for ash, vllimoto onalysis for oulfur)

- Highor hoating voluo. 


\section{INDIRECT HEAT EXCHANGER (CONT'D)}

11. Purpose (If multipurpose; describe percent in each use category)

Space Heat

Process Heot ......

Dener

ir ive of Eentral Equipment

$$
\begin{aligned}
& \text { Control Efficiency } \\
& \text { Particulates }
\end{aligned}
$$

Electrostatic Precipitator Cyclane

- Multiple Cyclone

Wet Scrubber

Settling Chamber

Other (Specify)
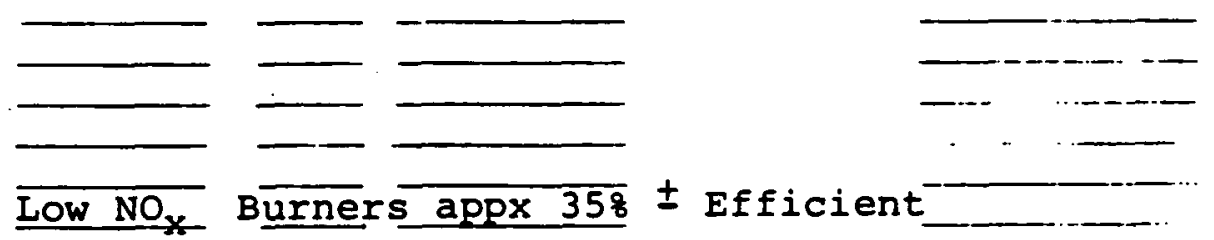

12. Stock

A. Outlet temperature $\quad-450-{ }^{\circ} \mathrm{F}$ $f t ' \sec$

C. Height 200 feet

2. Inside diameter (outlet) 72 _- inches

E. Number of sampling ports provided 2

F. Nearest distance from sampling port downstroam to stack outlet, bend or obstruction to ie determined feet

G. Nearest distance from sampling port upstream so bend or obstruction to be determined feet

H. List other sources vented to this stack NONE

13. Combustion air: Natural draft Induced

Forced prossure $\mathrm{X}$ lbs./sq.in. Pressure not known

Excess air (total oir supplied in excess of theoretical air required) $\sigma_{c}$

14. Describe fuel transport, storage methods and related dust control meosures.

will pump oil from a day tank

15. Describe fly osh (or other collected air contaminants) disposal, rransportation methods and related dust control meosures.

Not Applicable

16. Artach manufacturer's literoture and guaranteed performance dato for the indirect heat exchenger and ais pollution control equipment. Include information concerning fuel input, burners and combustion chamber dimensions.

To be supplied later after purchase 


\section{DEPARTMENT FOR \\ NATURAL RESOURCES AND \\ ENVIRONMENTAL PROTECTION \\ (iI VISION OF AIR POLLUTION \\ FRANK FORT, KENTUCKY 40601 \\ INDIRECT HEAT EXCHANGER}

A rumpieset form (No. APC 110 a) shall be submitted for each individual unit. The following types of units ore exempted irom ihis portion of the applicotion:

A. Indiect heat exchangers used solely for heating residential buildings not exceeding o totol of six oportment units;

B. New installations with a capocity of less than 1 million BTU per hour input;

C. Nox insta!lations using natural or liquified petroloum gas, including tho se hoving distill cie fue! sil as standby fual with a capacity of less than 50 million BTU per hour input;

D. Marine installations and locomotives;

E. Iniernal combustion engines and vehicles used for transportation of passengers or freight.

If your indirest heat exchanger is in one of the above categories please check that category and distegard the remaining portions of APC $-110 \mathrm{~A}$.

New instailations are those for which construction commenced ofter April 9, 1972.

2. Type of Unit Dowtherm Heater* H-2301

B. Manufacturer's Modol Number Later*

i. Rated Capactiy-Input (BTU/Hr.) $142 \mathrm{millilon} \mathrm{BTU/HR}$

1 Typo of Combustion Unit (Coal) With fly ash reinjection
A. Colverized
Dry Botrom
Wot Bottom

A. Manufoctorer's Name

C. Dote Installed Without fly ash reiniection

C. Stoker-fired Spreader Sioker Other Stoker

E. Cyclone

D. Hond-fired

E. Other (Specify) Oil Eired

j. Fype of Combustion Unit (oil)
A. Tangentially-fired
B. Horizontally-fired
To be Determined Later

ఏ. Tipe of Combustion Unit (Wood)

With fly ash rainjection

Without Hy osh.reinjection

A. File NA
B. Thin Bed
$\because$. Cyclonic

* The Dowtherm Heater has not been purchased. Data specific to the heater will be supplied when purchased later. 
Type and wuontiry of Fuol (Li st both primary and atondby):
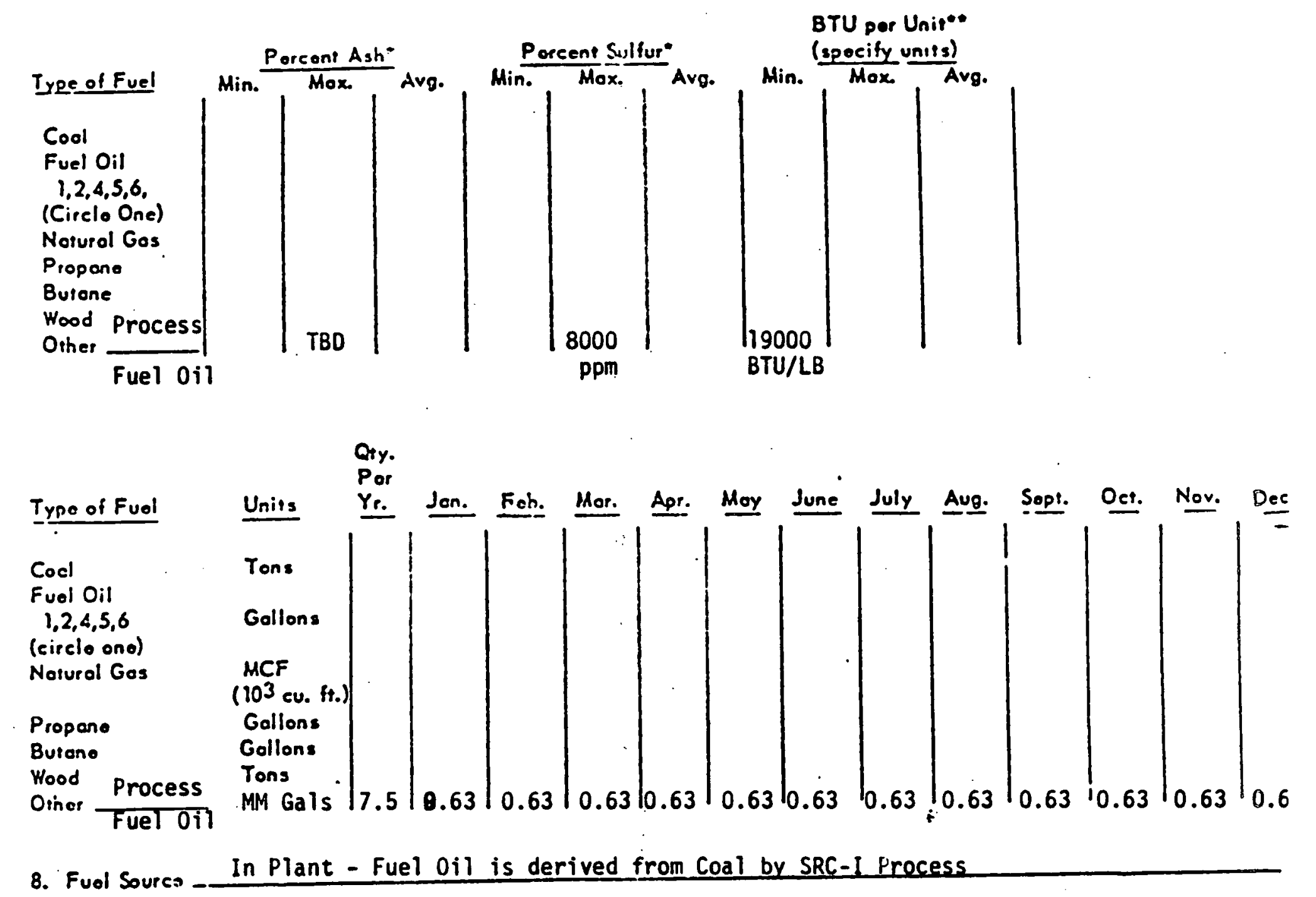

9. Normul Ofmoting Schodula:

47. Wooks per yoor, 7 Eoys por wue::, 24 Mours per doy

- As rocoivód bosis (Proximate onolysis for osh, ultimato onolysis for sulfur)

- Highor hoating voluo. 


\section{INDIRECT HEAT EXCHANGER (CONT'D)}

n. Purpose (If multipurpose, describe percent in each use cofegory)

Space Hoot

Process Heot ...

Dener...........

$\because$ ivoe of Eentrol Equipment

$$
\begin{gathered}
\text { Control Efficiency } \\
\text { Porticulotes } \\
\mathrm{SO}_{2} \text { Other (Specify) } \\
\end{gathered}
$$

S. is of Estimote

Co

- Electrostatic Precipitotor Cyclone

_. Multiple Cyclone

- .... Wet Scrubber

.._. Settling Chamber

.... Oiher (Specify)
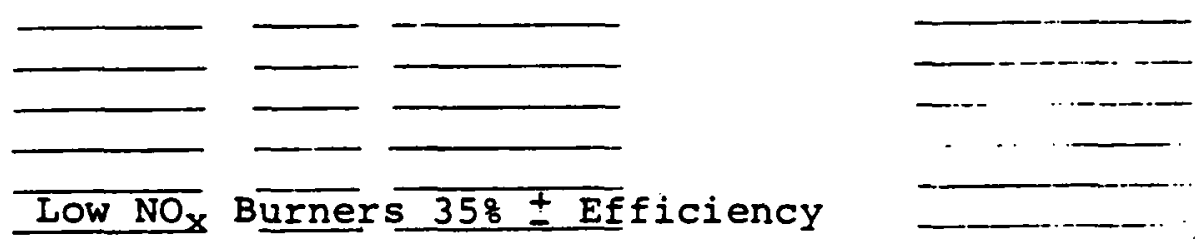

12. Srock
A. Outles temperature _- $\frac{590}{50}{ }^{\circ} \mathrm{F}$
B. Outlet velocity $\quad 50$
C. Height 200 feet
7. Insido diameter (outlet) 54 _-inches
E. Number of sampling ports provided $\frac{2}{2}$
F. Nearest distance from sompling port downstream to stock outlet, bend or obstruction to be determined feet
G. Nearest distance from sampling port upstream to bend or obstruction to be determined feer
H. List other sources ventod to this stock None

13. Combustion air: Notural draft

Indueed

Forced pressure $\mathrm{X}$ lbs./sq.in. to be determined

Excess air (total air supplied in oxcess of theoretical air required) to be determined

14. Describe fuel transport, storoge methods and related dust control meosures.

Fuel oil will be pumped from a day tank

15. Describe fly ash (or other collocted air contaminants) disposal, transportation methods and related dust control meosures.

Not applicable

16. Atfoch manufacturer' s liferature and guaranteed performence data for the indirect heat exchanger and air pollution control equipment. Include information concerning fuel input, burners and combustion chomber dimensions.

Heater has not been purchased. This info will be supplied later. 


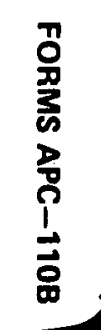


OFPARTMENT FOR

NATURAL RSSOURCES AND

ENV IRONHENTAL PROTECTION

OIVISIGN OF AIR POLLUTION

FRAIK FORT, KENTUCKY 40601

MANUFACTURING OR PROCESSING OPERATIONS $\log v \ldots \ldots$

COAL STORAGE AND TRANSFER - AREA 11

I. Normol Sihodule of Opecotion
A Hours por doy (1)
B. Doys por wook
7
C. Wooks per yoor 47 .
D. Pock protuction sooson (circlo ono) (1) sioody your round (2) summor (3) foll (1) winter (5) spring

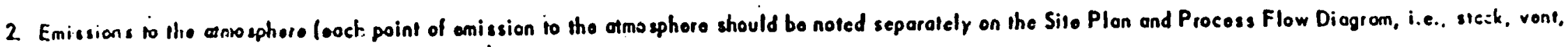
orid olhe: points of discherga 10 the ormosphoro).

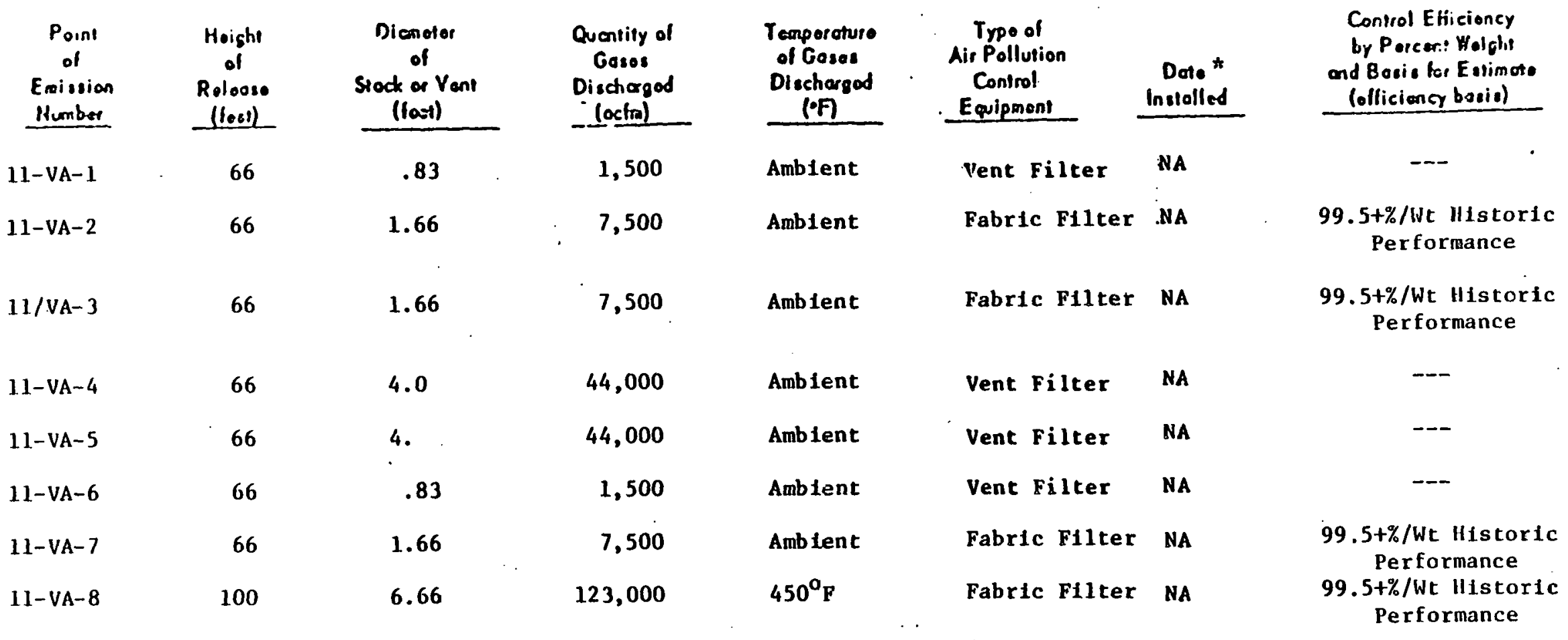

(1) - Coal rail car unloading - $2.4 \mathrm{Hrs} / \mathrm{Day}$

- Transfer and storage - 8 lirs/Day

- Coal Pulverizing and drying - 24 Hrs/Day

- Coal. Grinding System - 24 Hrs/Day 
Coal storage and Iransfer Area II
DFPARTMENT FOR

NATURAL RESOURCES ANO

ENV IRONHENT AL PROTECTION

OIVISION OF AIR POLLUTION

FRAIIK FORT, KENTUCKY 40601

\section{MANUFACTURING OR PROCESSING OPERATIONS}

2 Emlasions to the of no cophere (Continued)

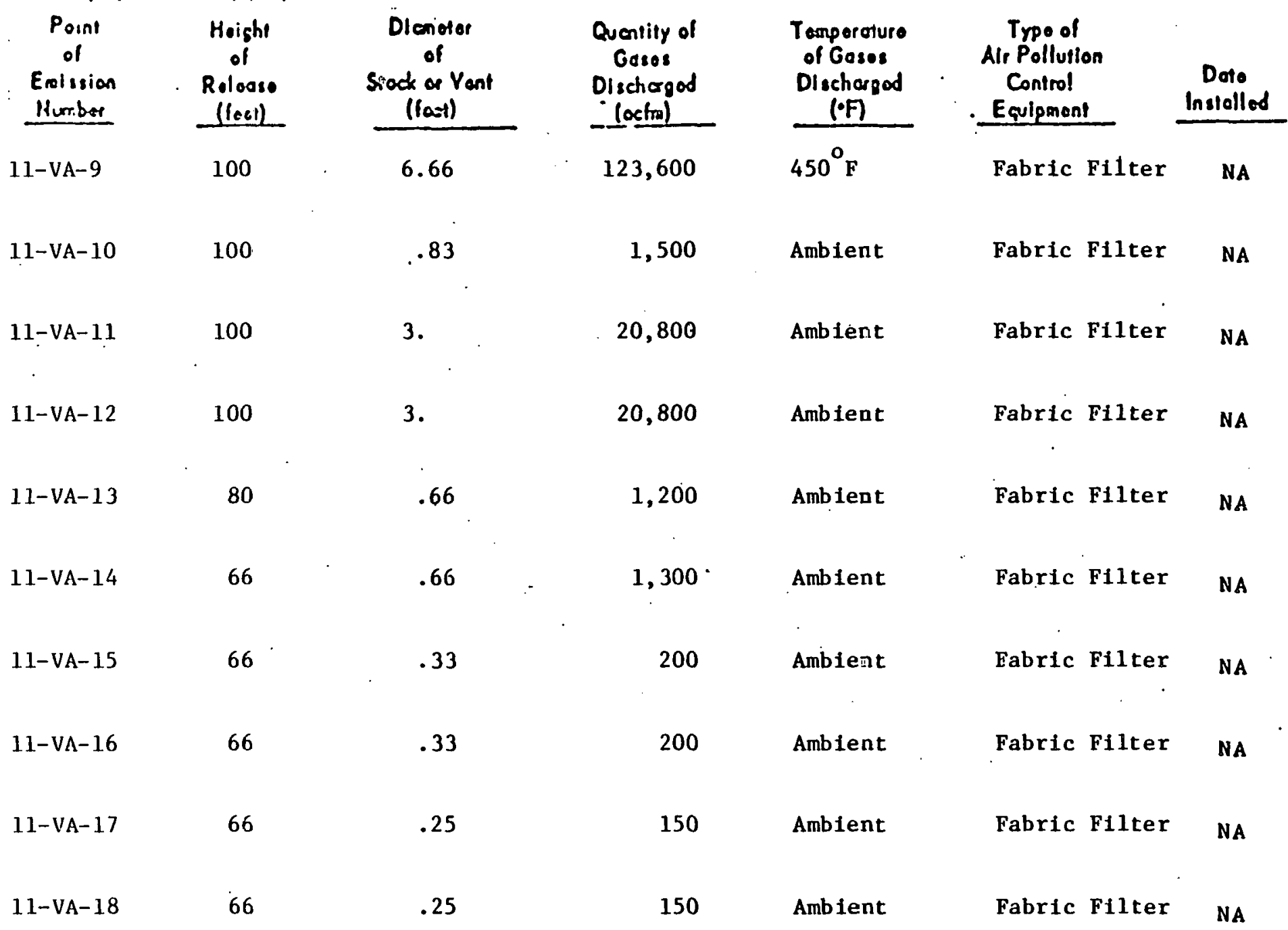

$-1 A-$ $\log \theta \ldots \ldots$

\begin{tabular}{l} 
Control Efficlency \\
by Porcer: Wolghi \\
and Bosis tor Estimose \\
(olficleng bosis) \\
\hline
\end{tabular}

$99.5+\% /$ Wt llistoric Performance

$99.5+\% /$ Wt llistoric Performance

$99.5+\% /$ Wt llistoric Performance

$99.5+\% /$ Wt Historic Performance

$99.5+\% / W t$ llistoric Performance

$99.5+\% /$ Wt llistoric Performance

$99.5+\% /$ Wt llistoric Performance

$99.5+\% / W t$ Historic Performance

$99.5+\% /$ Wt Historic Performance

$99.5+\% /$ Wt llistoric Performance

APC 1108 (Rov. 10/2) 
Coal Sturage and Transfer

3. Mcnulicturing or Procossing Units (list all procosses or operations)

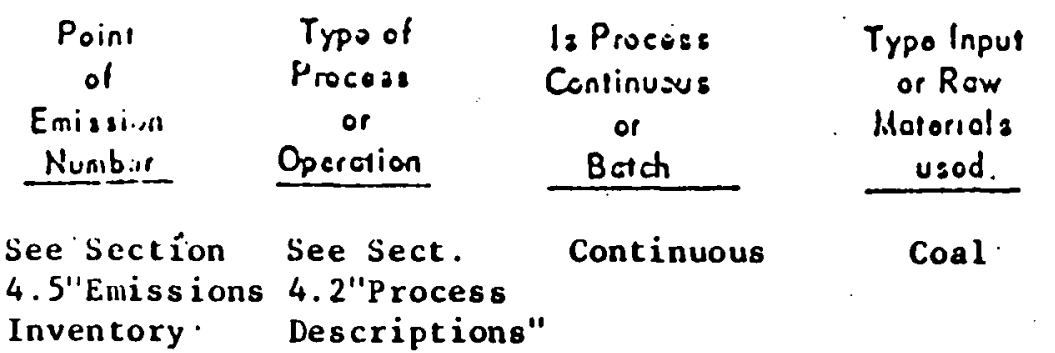

1. Equipt. int uesd in ooch procoss or oforation

Point il

Numlor

11-VA-1

$11-V A-2$

11-VA-3

$11-V A-4$

(1)

11-VA-5

$11-V_{A}-6$

" "

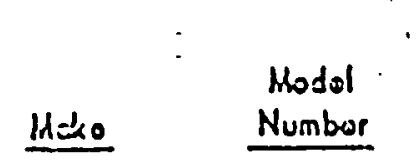

Data to be...

furnished

as scion as

available

\begin{tabular}{|c|}
\hline $\begin{array}{l}\text { Moximum } \\
\text { Quantity Inpus } \\
\text { por Hour } \\
\text { (apocify units) }\end{array}$ \\
\hline \\
\hline Dry \\
\hline
\end{tabular}

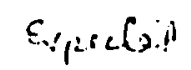

, Neremil

Oporating

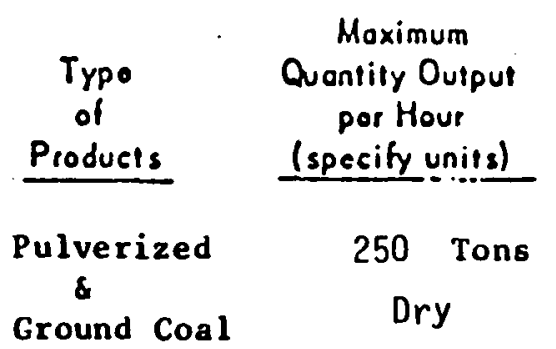

Ground Coal

Dry
Averoge Quentity

Oulput

por Yoor

(specily unila)

$2.64 \times 10^{6}$ Tons

Copocity

(spocify units)

(acfor)

1500

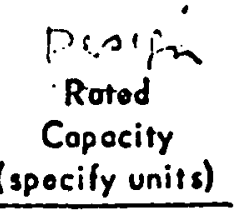

7500

7500

44,000

44,000

1500

Doto

Instalied

$\dot{\mathrm{N}} \mathrm{A}$

NA

NA

NA

NA

NA 
Coal Storage and Transfer Area 11

MANUFACTURIIIS OR PROCESSING OPERATIONS (conI'd)

$\log$

1. Equipc. int usot in each procoss or oporotion (Continued)

\begin{tabular}{|c|c|c|c|c|c|c|c|}
\hline $\begin{array}{l}\text { Point of } \\
\text { Emission } \\
\text { Numlor }\end{array}$ & $\begin{array}{r}\text { Th } \\
\text { of } \\
\text { Equip } \\
\end{array}$ & mont & Mako & $\begin{array}{l}\text { Modal } \\
\text { Numbor }\end{array}$ & $\begin{array}{c}\text { Oporcting } \\
\text { Copocity } \\
\text { (spocify units) } \\
\end{array}$ & $\begin{array}{c}\text { Rotod } \\
\text { Copocity } \\
\text { (specify units) } \\
\end{array}$ & $\begin{array}{l}\text { Doto } \\
\text { Instolled }\end{array}$ \\
\hline $11-V A-7$ & Fabric & Filter & Dat a to be & & 7500 & Data to be & NA \\
\hline $11-V A-6$ & $"$ & " & furnished a & & 123,000 & $\begin{array}{c}\text { furnished as soon } \\
\text { as available }\end{array}$ & NA \\
\hline $11-V A-9$ & $"$ & $"$ & soon as & & 123,600 & & NA \\
\hline $11-V A-10$ & $"$ & $"$ & available & . & 1500 & & NA \\
\hline $11-V A-11$ & $" 1$ & $"$ & & & 20,800 & & NA \\
\hline $11-V A-12$ & $"$ & $"$ & & & 20,800 & & NA \\
\hline $11-V A-13$ & $"$ & $"$ & & & 1200 & & NA \\
\hline $11-V A-14$ & $"$ & $"$ & & & 1300 & & NA \\
\hline $11-V A-15$ & " & $"$ & & & 200 & & NA \\
\hline $11-V A-16$ & $" 1$ & $"$ & . & & 200 & & NA \\
\hline $11-V A-17$ & $"$ & $"$ & & & 150. & & NA \\
\hline $11-V A-18$ & $"$ & $"$ & & & 150 & & NA \\
\hline
\end{tabular}


5. Fuol use ard equipmenl loe procoss hout excluding hoct suppliod by indiroci hoor oxchongor (Seo Form No. APC I10A for indiroct hoat oxchongors)

\begin{tabular}{|c|c|c|c|c|c|c|c|}
\hline $\begin{array}{c}\text { Poins } \\
\text { of } \\
\text { Ensission } \\
\text { Nurstur } \\
\end{array}$ & $\begin{array}{l}\text { Type } \\
\text { of } \\
\text { Fual }\end{array}$ & $\begin{array}{l}\text { Fual Usogs } \\
\text { Qucillty nlour } \\
\text { (siseclly units) } \\
\end{array}$ & $\begin{array}{c}\text { Racd } \\
\text { Bumce } \\
\text { Couseily } \\
\text { (BTU/Hour) } \\
\end{array}$ & $\begin{array}{c}\text { Porcent } \\
\text { Sullur }\end{array}$ & $\begin{array}{c}\text { Porcont } \\
\text { Ash }\end{array}$ & $\begin{array}{c}\text { Typo of } \\
\text { Air Pollution } \\
\text { Control Equipmont }\end{array}$ & $\begin{array}{l}\text { Control Elficioncy } \\
\text { by Porconl Woight } \\
\text { and Basis bor Estimete } \\
\text { (oflicioncy bosio) }\end{array}$ \\
\hline $11-V A-8$ & Process Gas & $49,462 \mathrm{ft}^{3} / \mathrm{Hr}$ & $\begin{array}{l}20 \cdot 44 \times 10^{6} \text { Btu } \\
\text { Output }\end{array}$ & $5 \mathrm{ppm}$ & - & Fabric Filter & $\begin{array}{l}99.5+\% / \text { Wt Historic } \\
\text { Performance }\end{array}$ \\
\hline $11-V A-9$ & Process Gas & $49,462 \mathrm{ft}^{3} / \mathrm{Hr}$ & $\begin{array}{l}\text { 20 } 44 \times 10^{6} \text { Btu } \\
\text { Output }\end{array}$ & 5 ppm & - & Fabric Filter & $\begin{array}{l}99.5+\% / W t \text { Historic } \\
\text { Performance }\end{array}$ \\
\hline
\end{tabular}

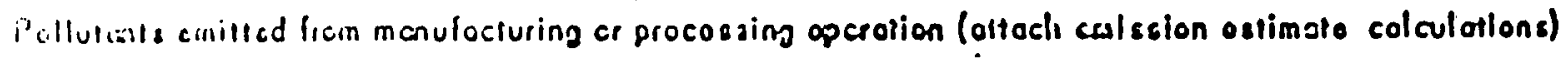

i......

$$
\text { riclis }
$$

\begin{tabular}{c} 
of \\
Emision \\
Numbor \\
\hline
\end{tabular}

$11-V A-01$

11-VA-02

$11-V A-03$

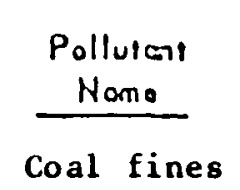

Chemical
Composition

"See Section.

4.5 Emissioas

inventory"

$\frac{\begin{array}{c}\text { Inlat } \\ \text { Lcouing } \\ \text { (oroind/SCF) }\end{array}}{\text { TBD }}$

"

"

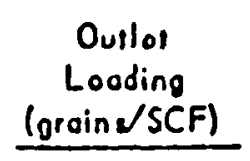

0.01

"

\begin{tabular}{c}
$\begin{array}{c}\text { Amount Emittod } \\
\text { Pounds Hour }\end{array}$ \\
\hline 0.13 \\
0.64 \\
0.64
\end{tabular}

\section{Boul: \\ of \\ Emiscion \\ Ealimate}

Manufacturer's Historic Operating Data "I

1 
Coal storage and Transfer Area 11

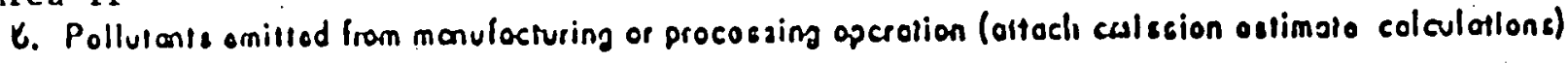

\begin{tabular}{|c|c|c|c|c|c|c|c|c|c|c|}
\hline $\begin{array}{l}\text { Polin! } \\
\text { of } \\
\text { Emision } \\
\text { Numbor }\end{array}$ & \multicolumn{2}{|c|}{$\begin{array}{c}\text { Pollular } \\
\text { Nome }\end{array}$} & $\begin{array}{l}\text { Chemicol } \\
\text { Composition }\end{array}$ & & $\begin{array}{c}\text { Inlot } \\
\text { Locuing } \\
\text { (groind SCF) }\end{array}$ & $\begin{array}{c}\text { Outlot } \\
\text { Looding } \\
\text { (groind SCF) } \\
\end{array}$ & \multicolumn{2}{|c|}{$\begin{array}{c}\text { Amount Emittod } \\
\text { Pounds Hour }\end{array}$} & \multicolumn{2}{|c|}{$\begin{array}{c}\text { Bosis } \\
\text { of } \\
\text { Emission } \\
\text { Estinoto } \\
\end{array}$} \\
\hline $11-V A-04$ & Coal & fines & See Section & 4.5 & TBD & 0.01 & 3.77 & & Manufactu & drers \\
\hline $11-V A-05$ & $"$ & $1 "$ & "Emissions & & +. " & 11 & 3.77 & • & Historic & Operating \\
\hline $11-V A-06$ & ". & $"$ & Inventory" & & $"$ & 11 & 0.13 & & Dat a & $\dot{3}$ \\
\hline $11-V A-07$ & $"$ & $"$ & $"$ & . & $"$ & 11 & 0.64 & & $"$ & ${ }^{\circ}$ \\
\hline $11-V A-08$ & $"$ & $" 1$ & $"$ & & $"$ & $"$ & 6.17 & & 11 & \\
\hline $11-V A-09$ & $"$ & $"$ & $"$ & & $"$ & $"$ & 6.17 & & $"$ & \\
\hline $11-V A-11$ & "1: & $1 "$ & $"$ & & $"$ & $"$ & 1.78 & & $"$ & \\
\hline $11-V A-12$ & ". & $" 1$ & $"$ & & 11. & $"$ & 1.78 & & $"$ & \\
\hline $11-V A-13$ & " & $"$ & $"$ & & $"$ & $"$ & 0.10 & & $"$ & \\
\hline $11-V A-14$ & 11 & $" 1$ & $"$ & & $"$ & $" 1$ & 0.11 & & $" 1$ & \\
\hline $11-V A-15$ & $"$ & $"$ & $"$ & & $" 1$ & $"$ & 0.02 & & $"$ & \\
\hline $11-V A-16$ & $"$ & $" 1$ & $"$ & & $"$ & $"$ & 0.02 & & $"$ & \\
\hline $11-V A-17$ & $"$ & $"$ & $"$ & & $"$ & 11 & 0.01 & & $"$ & \\
\hline $11-V A-18$ & ". & $"$ & $"$ & & $"$ & $"$ & 0.01 & & $"$ & \\
\hline
\end{tabular}


7. Doscribs thorgas and traisportation of prasassod and row matorials and ralatod air pollution control moosures.

See Section 4.2 Area Process Descriptions

8. Descrits disposch, re-usc, starcjz, and transportalion of conforsincats celloctad by air pollution control dovicos. Indicate the woight of eoch contaminant

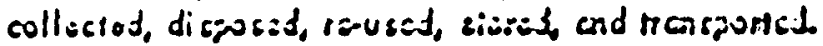

Pollutant collected is coal dust which is returned to the system in every case. Inlet loadings to each fabric filter are unknown at this time which prevents the calculation of the weights of particulate collected.

9. Subnit a Procoss Flow Diszren. Labzl: (1) input of row matorials, (2) production procasses, process fuel combustion, procoss equipmant and air pollution control a wuipancns, and (3) all numbarod peinis ol emission of air centenlnents.

See Section 4.3 Process Flow Sheets". 
SRC PROCESS

AREA 12
DEPARTIACATT FOR

PIATURAL RESOURCES AND

ENV!KONHENT AL PROTECT ION

OIVISION OF AIR FOLLUTION

FRARK FORT, KENTUCKY 40601 $\log \|$

MNIUFACTURING OR PROCESSING OPERATIONS

1. Normal Sichodule of Opsiation

A. Heurl for day 24

B. Doyi por wosk

7

C. Wooks por yoor 47

D. Pscli protuction sioson (circle ono) (11)) siocdy yoor round (2) summor
(3) foll
(4) winter
(5) spring

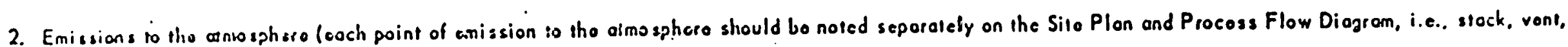
ard orhe: points of disclierge to the orinosphoro).

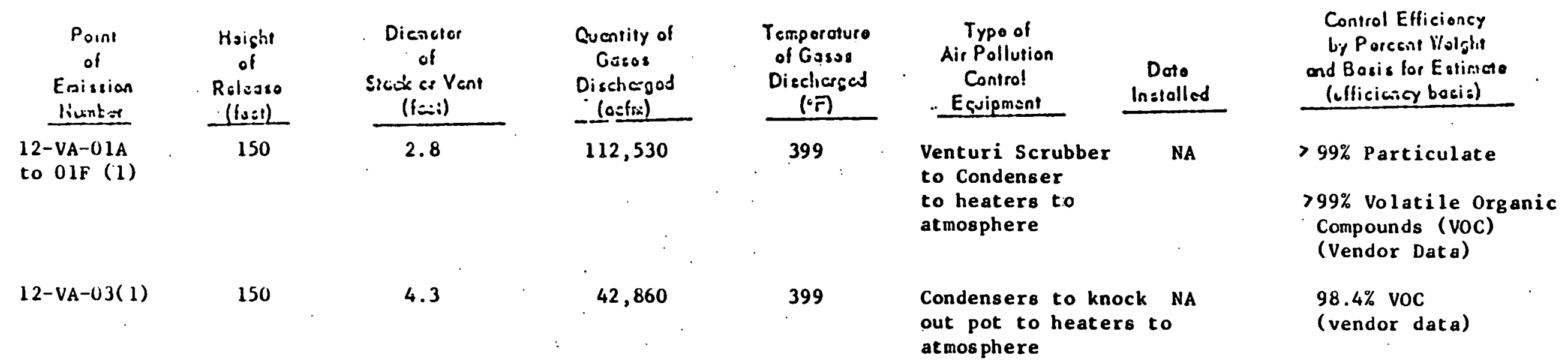

(1) The processes identified above represent those portions of emissions exiting stacks 12-VA-01A.to 01F and 12-VA-03 coming from the "Coal Slurry drums" ( $V-12201$ A\&Bi) and the "Recycle Critical Solvent Accumulator Vessels", (V 12706 A\&B) respectively. The Coal Slurry drum emissions pass through venturi scrubbers, condensers and heaters before exiting out 12-VA-01A to 01F. The Solvent Accumulator Vessel emissions pass through condensers/knock out pot and heaters before exiting out 12-VA-03. See Section 8.0 "BACT Proposals". 
3. Manuliceturing or Procorsing Units (list all procossos or oporations)

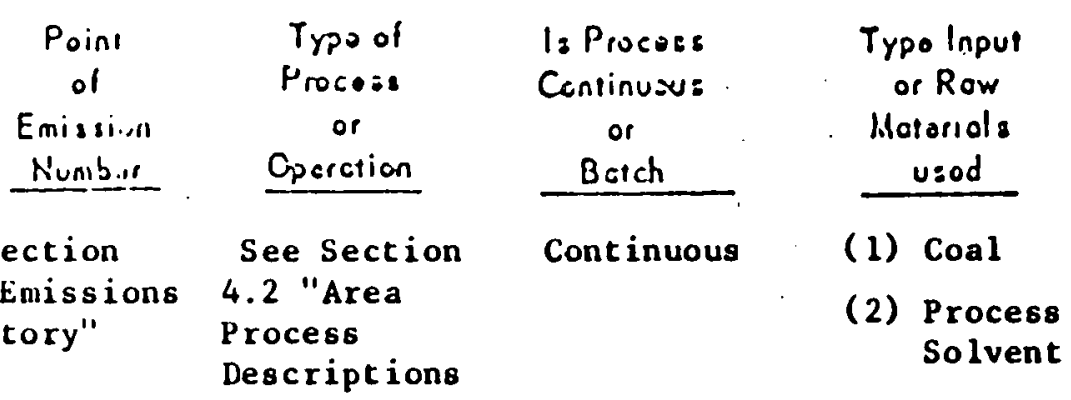

Maximum
Quantity Inpul
por Hour
(apscily units)
Coal 475,000 lbs.
Solvent
786,000 1bs.

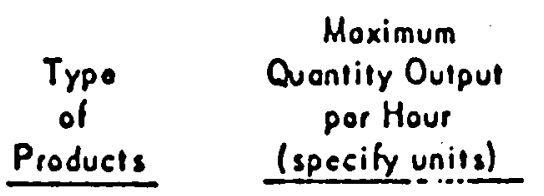

Molten SRC

Medium oil

Heavy Oil

Ash concentrate

See Section 4.4

"Materials Balances"
Avoroge Quentily

Oulput

por $Y_{0 \alpha}$

(specily units)

910,800 tons

166,320 tons

102.960 tons

498,960 tons

1. Equiph.int usst in ooch procoss or of orotion

\begin{tabular}{|c|c|c|}
\hline $\begin{array}{l}\text { Point of } \\
\text { Emission } \\
\text { Numtor }\end{array}$ & $\begin{array}{c}\text { Typo } \\
\text { of } \\
\text { Equipmont } \\
\end{array}$ & $\begin{array}{l}\text { Hodol. } \\
\text { Numbor }\end{array}$ \\
\hline $\begin{array}{l}12-V A-01 A \\
\text { to } 01 F\end{array}$ & $\begin{array}{l}\text { Venturi Scrubber } \\
(\mathrm{J}-12201 \text { A\&B } / \\
\mathrm{V}-12202 \mathrm{~A} \& \mathrm{~B})\end{array}$ & $\begin{array}{c}\text { Data will be .. } \\
\text { furnished as }\end{array}$ \\
\hline & $\begin{array}{l}\text { Condenser } \\
(E-12204 \text { A\&B/ } \\
\text { V-12204) }\end{array}$ & soon as available \\
\hline & $\begin{array}{l}\text { Heaters } \\
(11-12301 \quad A-F)\end{array}$ & \\
\hline
\end{tabular}

\author{
Sip:c6.1 \\ Noim:l \\ Opsrating \\ Copocity \\ (spocify units) \\ $4700 \mathrm{sccfm}$ \\ $2230 \mathrm{scfm}$
}

335 MM BTU/HR

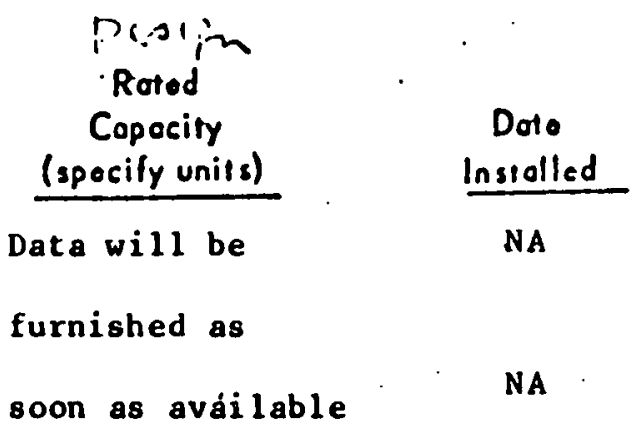

NA 


\section{MANUFACTURIIIO OR PROCESSING OPERATIONS (conI'd)}

$\log$

1. Equipt.int used in eoch procoss or oporotan (Continued)

\begin{tabular}{|c|c|c|}
\hline $\begin{array}{l}\text { Point of } \\
\text { Emissiun } \\
\text { Numlor }\end{array}$ & $\begin{array}{c}\text { Typo } \\
\text { of } \\
\text { Equipmont }\end{array}$ & $\begin{array}{l}\text { Modol . } \\
\text { Numbor }\end{array}$ \\
\hline-03 & $\begin{array}{l}\text { Condenser/Knock } \\
\text { out pot }(E-12704 \\
A \& B / V-12715)\end{array}$ & $\begin{array}{l}\text { Data will be } \\
\text { furnished as } \\
\text { Available }\end{array}$ \\
\hline & $\begin{array}{c}\text { Heaters } \\
(H-12701)\end{array}$ & \\
\hline
\end{tabular}

$\begin{gathered}\text { Oporoting } \\ \text { Copociory } \\ \text { (spocify units) }\end{gathered}$
$1128 \mathrm{cfm}$

128 MM BTU/HR

$\begin{gathered}\text { Rotod } \\ \text { Copocity } \\ \text { (specily units) }\end{gathered}$
Data will be
furnished as
avail able-

avai lable-
Doto Inslolled

NA

NA 
5. Fuol use and equipment lor process hoot excluding heor suppliad by indiroct hoot oxchangor (Seo Form No. APC 110A for indirect hoot oxchangors)

\begin{tabular}{|c|c|c|c|c|c|c|c|}
\hline $\begin{array}{l}\text { Poinl } \\
\text { of } \\
\text { Enission } \\
\text { Numter }\end{array}$ & $\begin{array}{l}\text { Trpe } \\
\text { of } \\
\text { Fual }\end{array}$ & $\begin{array}{l}\text { Fual Usogs } \\
\text { Questlty flour } \\
\text { (ascelfy units) }\end{array}$ & $\begin{array}{l}\text { Roted } \\
\text { Bumce } \\
\text { Copseity } \\
\text { (BTU/Hour) }\end{array}$ & $\begin{array}{l}\text { Porcent } \\
\text { Sulfur }\end{array}$ & $\begin{array}{c}\text { Porcont } \\
\text { Ash }\end{array}$ & $\begin{array}{c}\text { Typo of } \\
\text { Air Pollution } \\
\text { Control Equipment }\end{array}$ & $\begin{array}{l}\text { Conlrol Ellicioncs } \\
\text { by Porconl Woight } \\
\text { and Boris for Eatimase } \\
\text { (officioncy basia) }\end{array}$ \\
\hline
\end{tabular}

NOT APPLICABLE

6. Pollutanis arnilted from monufocturing or procossing apcration (altacli caslestan ostimale colculations)

\begin{tabular}{|c|c|c|c|c|c|c|}
\hline $\begin{array}{c}\text { Polris } \\
\text { of } \\
\text { Emisuion } \\
\text { Numbor }\end{array}$ & $\begin{array}{l}\text { Pollutarl } \\
\text { Nome }\end{array}$ & $\begin{array}{l}\text { Chamical } \\
\text { Composition }\end{array}$ & $\begin{array}{c}\text { Inlot } \\
\text { Leóling } \\
\text { (oroind/SCF) }\end{array}$ & $\begin{array}{c}\text { Outlot } \\
\text { Looding } \\
\text { (graind SCF) } \\
\end{array}$ & $\begin{array}{l}\text { Amount Emittod } \\
\text { Pounds Hour }\end{array}$ & $\begin{array}{l}\text { Bosis } \\
\text { of } \\
\text { Emisuion } \\
\text { Estinate } \\
\end{array}$ \\
\hline $\begin{array}{l}\text { From: } \\
\text { V-12201 A\&B }\end{array}$ & $\begin{array}{l}\text { VOC } \\
\text { Particula:e }\end{array}$ & $\begin{array}{l}(1) \\
(2)\end{array}$ & - & 11.62 & $\begin{array}{r}27,028 \\
466\end{array}$ & $\begin{array}{l}\text { Process Data and } \\
\text { Materials Balances }\end{array}$ \\
\hline $\begin{array}{ccc}\text { To: } & J-12201 & A G B \\
\& & V-12202 & A G B\end{array}$ & $\begin{array}{l}\text { VOC } \\
\text { Particulate }\end{array}$ & $\begin{array}{l}\text { (1) } \\
(2)\end{array}$ & $\overline{11.62}$ & 1.22 & $\begin{array}{r}11,899 \\
23.3\end{array}$ & " \\
\hline $\begin{array}{cl}\text { To: } & E-12204 \text { A\&B } \\
\text { \& } & V-12204\end{array}$ & $\begin{array}{l}\text { VOC } \\
\text { Particulate }\end{array}$ & $\begin{array}{l}\text { (1) } \\
\text { (2) }\end{array}$ & 1.22 & $4.49(3)$ & $\begin{array}{l}6 \\
4.7\end{array}$ & $"$ \\
\hline To: $11-12301 \mathrm{~A}-\mathrm{F}$ & $\begin{array}{l}\text { VOC } \\
\text { Particulate }\end{array}$ & $\begin{array}{l}\text { (1) } \\
\text { (2) }\end{array}$ & 4.49 & - & $\begin{array}{l}(4) \\
(4)\end{array}$ & $\pi$ \\
\hline
\end{tabular}

To: 12-VA-01A to 01F

(1) Volatile organic carbong-average boiling points $100-250^{\circ} \mathrm{F}$ to $750-850^{\circ} \mathrm{F}$.

(2) Particulate is coal dust.

(3) Higher outlet loading due to large decrease in vapor volume.

(4) See Section 4.5. "Emissions inventory". 
6. Pollutants amiltad from manulocturing or procosging apcrotion (altach caslscion ostimato colculationa)

\begin{tabular}{|c|c|c|c|c|c|c|}
\hline $\begin{array}{l}\text { Polint } \\
\text { of } \\
\text { Emistion } \\
\text { Humbor }\end{array}$ & $\begin{array}{l}\text { Pollutari } \\
\text { Nome }\end{array}$ & $\begin{array}{l}\text { Chamical } \\
\text { Composition }\end{array}$ & $\begin{array}{c}\text { Inlot } \\
\text { Lcouing } \\
\text { loroins/SCF) }\end{array}$ & $\begin{array}{c}\text { Outlor } \\
\text { Looding } \\
\text { (groindSCF) }\end{array}$ & $\begin{array}{c}\text { Amount Emitrod } \\
\text { Pounds Hour }\end{array}$ & $\begin{array}{c}\text { Bosis } \\
\text { of } \\
\text { Emiscion } \\
\text { Estimate } \\
\end{array}$ \\
\hline $\begin{array}{c}V-12706 \text { A\&B } \\
\text { to }\end{array}$ & voc & (1) & '- & - & $\begin{array}{l}5730 \text { maximum } \\
1363 \text { normal }\end{array}$ & $\begin{array}{l}\text { Process data and } \\
\text { Material Balances }\end{array}$ \\
\hline $\begin{array}{c}E-12704 \text { A\&B / } \\
V-12715 \\
\text { to }\end{array}$ & voc & (1) & - & - & $\begin{array}{l}91.7 \text { maximum } \\
21.8 \text { normal }\end{array}$ & $"$ \\
\hline$H-12701$ & voc & (1) & - & - & (2) & $"$ \\
\hline to & & . & & & & \\
\hline $12-V A-03$ & & & & : & & \\
\hline
\end{tabular}


7. Dascribs tlorgas and traneportation of procossod and raw motorials and rolotod air pollution control moasures.

All materials handling in the SRC process area are in totally enclosed systems.

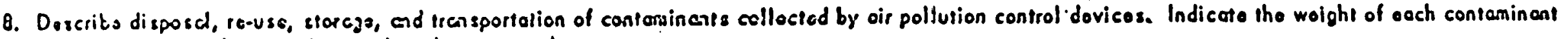

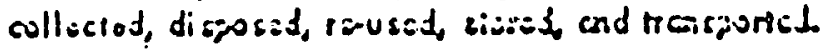

12-VA-01A Coal recovered by venturi scrubber separators (J-12201 A\&B/V-12202 A\&B) is recycled back to coal slurry drums $(V-12201 \mathrm{ASB})$, at the rate of $442.7 \mathrm{lbs} / \mathrm{hr}$.

VOC and particulate recovered by condensẹ acciumulators (E-12204 A\&B/V-12204) is recycled back to process, at a rate of $11,912 \mathrm{lbs} . / \mathrm{hr}$.

12-VA-03 VOC recovered by condensers, E-12704 A\&B/CSD vent knock-out pot, V-12715 is recycled back to process at a rate of $5638.3 \mathrm{lbs} / \mathrm{hr}$. maximum and $1341.2 \mathrm{lbs} / \mathrm{hr}$. normal.

9. Subnit a Procoss Flow Diejean. Labzl: (1) input of rov matoricls, (2) procuction procosses, process fuel combustion, procoss equipment and air pollulion control e puipanonl, and (3) cll numborod points of emission of air centeninarta.

Process flow sheets are included in Section 4.3. 


\section{MANUFACTURING OR PROCESSING OPERATIONS}

1. Normal Sthedule of Operation
A. Hzureper doy 24
B. Daye per wook
7
C. Wooks per yoar 47.0
D. Psok production seoson (circle on o) (II) sioody yocer round
(2) summor
(3) fall
(1) winter
(5) spring

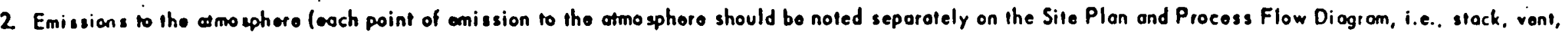
and othe: points of discharge to the ofmosphore).

\begin{tabular}{|c|c|c|c|c|c|c|c|}
\hline $\begin{array}{l}\text { Point } \\
\text { of } \\
\text { Enission } \\
\text { Number } \\
\end{array}$ & $\begin{array}{l}\text { Hoight } \\
\text { of } \\
\text { Reloose } \\
\text { (lool) } \\
\end{array}$ & $\begin{array}{l}\text { Dianeter } \\
\text { of } \\
\text { Siock or Vent } \\
\text { (foot) }\end{array}$ & $\begin{array}{l}\text { Qumity of } \\
\text { Gases } \\
\text { Dischargod } \\
\text { loefm) }\end{array}$ & $\begin{array}{l}\text { Temperature } \\
\text { of Gotes } \\
\text { Discharged } \\
\text { (०F) }\end{array}$ & $\begin{array}{l}\text { Trpo of } \\
\text { Air Pollution } \\
\text { Contro! } \\
\text { Equlpment }\end{array}$ & $\begin{array}{c}\text { Dote } \\
\text { Installod }\end{array}$ & $\begin{array}{l}\text { Conirol Efficioncy } \\
\text { by Percent Woloht } \\
\text { ond Bosi to Estimate } \\
\text { (officiency bosia) }\end{array}$ \\
\hline $13-V A-2$ & 18.37 & -- & 0.62 & Ambient & -- & $\begin{array}{l}\text { Not applicable } \\
\text { to new install- } \\
\text { ations }\end{array}$ & -- \\
\hline
\end{tabular}

$\begin{array}{ccccc}13-\mathrm{VA}-3 & 150.0 & 70540 & 190 & \begin{array}{l}\text { Venturi scrub- } \\ \text { ber }\end{array}\end{array}$

928 Particulate Removal

858 Sulfur dioxide removal

Manufacturers estimates

\begin{tabular}{|c|c|c|c|c|c|c|c|}
\hline $13-V A-4$ & 80.0 & 3.44 & 28000 & 350 & Dust Collector & " & $\begin{array}{l}\text { 98.7\% Particulate re- } \\
\text { moval } \\
\text { Manufacturers estimates }\end{array}$ \\
\hline $13-V A-5$ & 200.13 & 2.13 & 10690 & 109 & Dust collector & ". & $\begin{array}{l}\text { 99.7\% Particulate re- } \\
\text { moval } \\
\text { 1'anufacturers estimates }\end{array}$ \\
\hline $13-V A-6$ & 23.98 & -- & 0.62 & Ambient & $-\infty$ & $"$ & -- \\
\hline $13-V A-7$ & 80.0 & 2.13 & 10690 & 109 & Dust Collector & $"$ & $\begin{array}{l}99.7 \% \text { Particulate re- } \\
\text { moval } \\
\text { Manufacturers estimates }\end{array}$ \\
\hline
\end{tabular}


COI ND LIQUID FUEL AREA 13
….....

NATURAL RESOURCES AND

ENVIKONMENTAL PROTECVION

DIVISION OF AIR POLLUTION

FRAIJK FURT, KENTUCKY. 40601

MIANUFACTURING OR PROCESSING OPERATIONS

1. Normal S.hodule of Operotion
A Riurseper doy
1
B. Doye per wook
7
C. Wooks por yoar 47.0
D. I':id production seoson (circlo ono)
(II) sioody yoar round
(2) summor
(3) fall
(4) winter
(5) spring

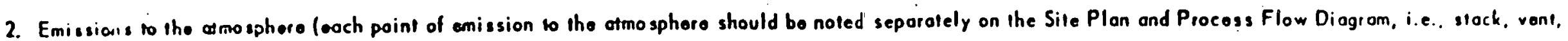
and ophe. points of dischorge to the atmosphere).

\begin{tabular}{|c|c|c|c|c|c|c|c|}
\hline $\begin{array}{l}\text { Poinl } \\
\text { of } \\
\text { Eriasion } \\
\text { Number }\end{array}$ & $\begin{array}{l}\text { Hoight } \\
\text { of } \\
\text { Reloose } \\
\text { lloill }\end{array}$ & $\begin{array}{l}\text { Dianof or } \\
\text { of } \\
\text { Stock or Vent } \\
\text { (fect) }\end{array}$ & $\begin{array}{l}\text { Quontity of } \\
\text { Gases } \\
\text { Discherged } \\
\text { (oche) }\end{array}$ & $\begin{array}{c}\text { Tomporofure } \\
\text { of Gosos } \\
\text { Discliargat } \\
\text { (०F) }\end{array}$ & $\begin{array}{l}\text { Typo of } \\
\text { Air Pollution } \\
\text { Coniro! } \\
\text { Equipmen! }\end{array}$ & $\begin{array}{l}\text { Doite } \\
\text { Installod }\end{array}$ & $\begin{array}{l}\text { Control Efficiency } \\
\text { by Porcent Violotit } \\
\text { and Basis tor Estimate } \\
\text { (officiency basio) }\end{array}$ \\
\hline romose & $\ln 12$ & & (1 hr/day) & & & & \\
\hline $13-V A-9$ & 33 & $-\infty$ & 0.62 & 201 & -- & Not applicable & -- \\
\hline
\end{tabular}


CO':E AND LIQUID FUEL AREA 13

3. Manul eturing or Procossing Unita (list all processes or oporations)

\begin{tabular}{|c|c|c|}
\hline $\begin{array}{l}\text { Poin: } \\
\text { of } \\
\text { Emial: } \\
\text { Numt: }\end{array}$ & $\begin{array}{l}T \text { re of } \\
\text { Pricene } \\
\text { or } \\
\text { Opiction }\end{array}$ & $\begin{array}{c}\text { 1. Process } \\
\text { Contincous } \\
\text { or } \\
\text { Botrh }\end{array}$ \\
\hline $\begin{array}{l}\text { ee Section } \\
5 \text {, Emis- } \\
\text { ions Inven- } \\
\text { ory }\end{array}$ & $\begin{array}{l}\text { See Section } \\
4.2 \text {, Area } \\
\text { Process } \\
\text { Descrip- } \\
\text { tions }\end{array}$ & Continuous \\
\hline
\end{tabular}
Typo Inpup
of Row
Motoriols.
usod

bolten solvent refined coal

Maximum
Cuartity Input
por Hour
(spocily units)
$147,666 \mathrm{lb} 3 / \mathrm{hr}$

\section{Stabilized}

Naphtha

ledium Oil

(llydrocracking

operation Prod)

Heavy Oil

Vacuum Residue

Medium Oil

(Coking Oper-

ation Product)
Moximum

Quantily Oulput

por Hour

(specify unirs)

$49,178 \mathrm{lbs} / \mathrm{hr}$

$2,076 \mathrm{lbs} / \mathrm{hr}$

$8,821 \mathrm{lbs} / \mathrm{hr}$

$11,9461 \mathrm{bs} / \mathrm{hr}$

$33,597 \mathrm{lbs} / \mathrm{hr}$

47,306 tons/yr

133,044 tons/yr

$6,211 \mathrm{lbs} / \mathrm{hr}$

$8,063 \mathrm{lbs} / \mathrm{hr}$
Averoge Quantily

Output per Yoor

(specily units)

194,745 tons/yr

8,221 tons/yr

34,931 tons/yr

24,596 tons/yr 31,929 tons $/ y x$

4. Equiph. at used in eoch procoss or oporation

$$
\begin{aligned}
& \text { Point .1 } \\
& \text { Emiss. "1 } \\
& \text { Hum! ! }
\end{aligned}
$$

13-VA-3

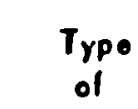

Equipmont

Venturi Scrubber

\section{Modal}

Mako

Data will

be fur-

nished when

available
Number

Data will

be fur-

nished when available

\begin{tabular}{lllllll}
\hline $13-\mathrm{VA}-4$ & Bag Filter & $"$ & $"$ & 28,000 ACFM & 28,000 ACFM & $" 1$ \\
\hline $13-\mathrm{VA}-5$ & Bag Filter & $"$ & $"$ & 8,600 ACFM & 8,600 ACFM & $" 1$
\end{tabular}


5. Fual use ard equipment for process hoot excluding heot supplied by indirect hoot oxchenger (Seo Form No. APC I10A for indirect hoot exchonger s)

Point

of

Emisuion

Number

13-VA-3

\begin{tabular}{c} 
Trpe \\
ol \\
Fual \\
\hline
\end{tabular}

Fual Usage

Quenility/Hour

(epecify units)

Fuel gas

\section{Roted}

Bumor

Copocity

(BTU/Hour)

$30.6 \frac{\mathrm{MM} \mathrm{BTU}}{\mathrm{hr}}$

TBD
Percent

Sultur

5 ppm

$\frac{\begin{array}{c}\text { Percent } \\ \text { Anh }\end{array}}{-}$

Control Elliciency by Porcent Woight and Basis tor Eatimato (ollicioncy bosia)

928 Particulate Removal

858 Sulfur Dioxide

Rennval.

Mamufacturers estimates 
2. Dascribe eloroge and transportation ol procossod and raw matorials and roloted air pollution control measures.

Prior to decoking the coke drum it is filled with water to cool and wet the coke. Following cooling the coke drum is decoked with water jets. The coke and water are sent through a crusher and sluiced to the coke pit. See Section 4.2 "Area Process Descriptions".

8. Descrits disposal, rouso, storoge, and transportotion of cantaminants collectod by air pollution control dovicos. Indicate the woight of each contaminant

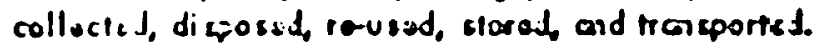

Point of

Emission

Sodium sulfite/bisulfite
Fly ash

$\underline{1 \mathrm{bs} / \mathrm{hr}}$

$125 / 20$

13-VA-4 Bag Filter

coke fines

209

13-VA-5 Bag Filter

Coke fines

420

13-VA-7 Bag Filter

Coke fines

420

420

\section{Disposal}

Sent to Waste Treatment Area 16. Sent to Waste Treatment Area 16.

\section{coke fines are collected and combined with} product stream.

coke fines are collected and combined with product stream.

coke fines are collected and combined with product stream.

9. Submit o Procoss Flow Diogram. Labol: (1) inpul of row motoriols, (2) proctuction procosses, process fuel combustion, process equipment and air pollution control a. uiparent, and ( 3 ) oll numberod points of omission of air contaminents.

Process flow sheets are included in Section 4.3. 
COKE AND LIQUID FUEL

AREA 13

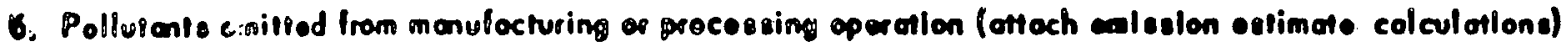

\section{Poline \\ of}

Emiscion

Number

13-VA-2

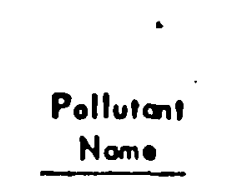

Volatile organic carbon

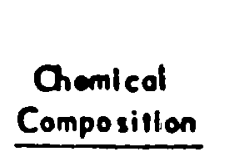

Light

hydrocarbons

Onlot
Looding
(groind/SCF) $\quad$\begin{tabular}{c} 
Lurlot \\
Looding \\
\hline
\end{tabular}

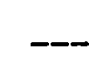

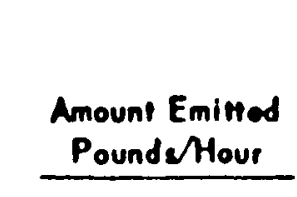

0.20

\section{Boale \\ of \\ Emierion \\ Ealimole}

Breathing losses, $20^{\circ} \mathrm{F}$ differential assumed

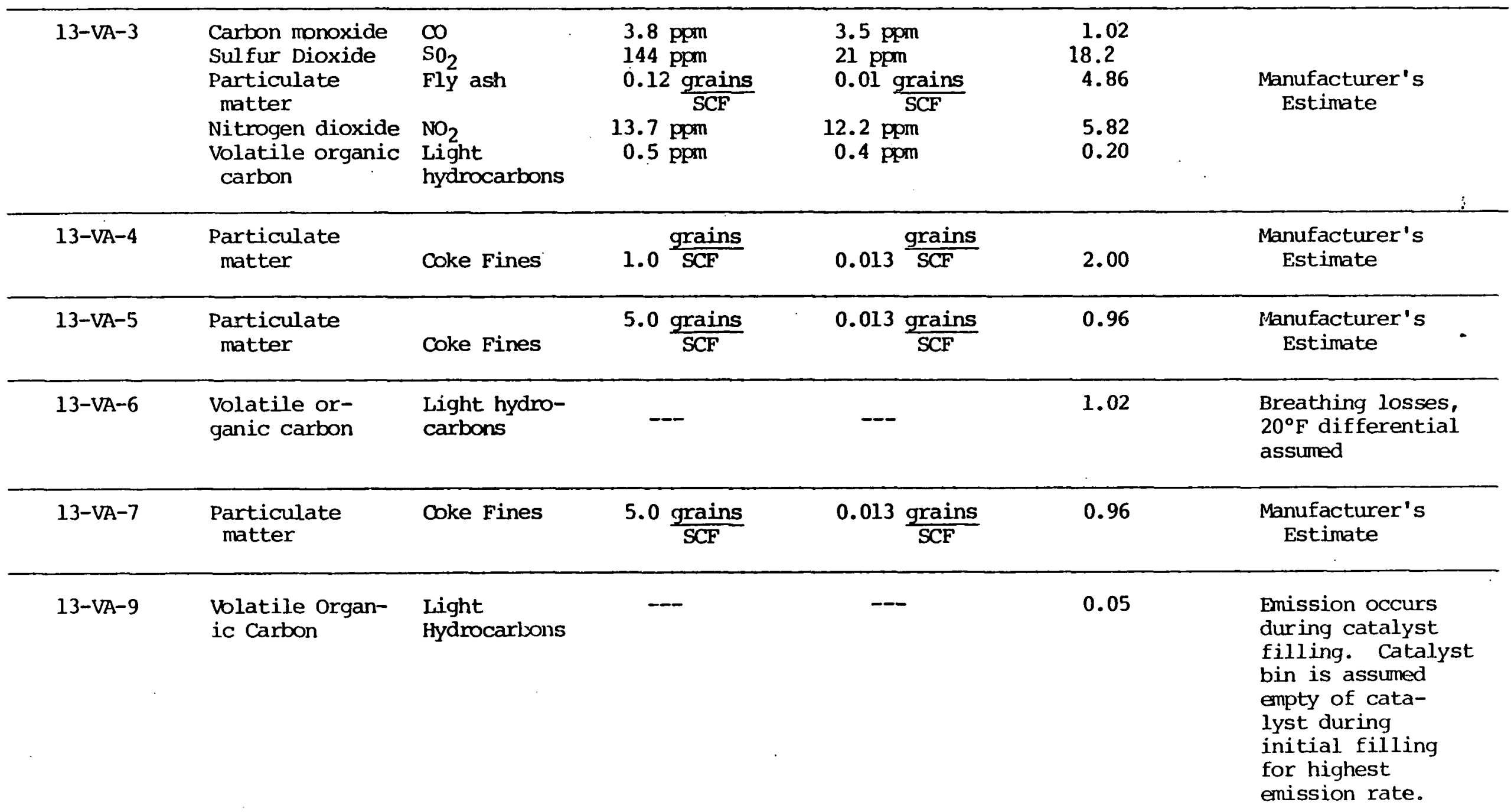


Air Separation Unit

Cryogenic Systems - Area 14

DFPARTMENT FOR

NATURAL RESOURCES AND.

ENV IRONHENTAL PROTECTIION

DIVISION OF AIR POLLUTION

FRAINK FORT. KENTUCKY 40601

\section{MANUFACTURING OR PROCESSING OP ERATIONS}

1. Normal Schodule of Opiration

A. Hours por doy 24

B. Doye por wock

C. Wooks por yoor

47

D. Pude profuction swason (circle ono) (i) sioaty yoar round

(2) sumnor

(3) lall

(4) wintor

(5) spring

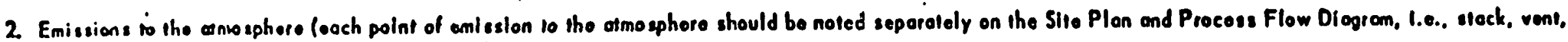
orid othes points of discliargo to the ofmosphere).

\begin{tabular}{|c|c|c|}
\hline 1 & 2 & 3 \\
\hline $\begin{array}{l}\text { Point } \\
\text { ol } \\
\text { Emision } \\
\text { Ilumbor }\end{array}$ & $\begin{array}{l}\text { Maight } \\
\text { of } \\
\text { Rolcoses } \\
\text { (loct) }\end{array}$ & $\begin{array}{c}\text { Dienolor } \\
\text { of } \\
\text { Siack or Vent } \\
\text { (le-il) }\end{array}$ \\
\hline
\end{tabular}

4
Quanility of
Gases :
Dischergod
- locine)

449

\begin{tabular}{l} 
Temperoture \\
of Gosos \\
Dlechargod \\
( $F)$ \\
\hline
\end{tabular}

325
Typo of Air Pollution

Coniro!

Equipmont

None

\section{Date}

Inelollod

Not App11cable $\log$

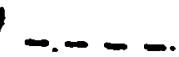

4.0

.0

(n)

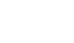

325


3. Manuliceturing or Processing Units (Ilst oll processes or oporotiona)

\begin{tabular}{|c|c|c|c|c|c|c|c|}
\hline $\begin{array}{c}\text { Point } \\
\text { of } \\
\text { Emission } \\
\text { Numbor } \\
\end{array}$ & $\begin{array}{l}\text { Trpe of } \\
\text { Procese } \\
\text { or } \\
\text { Operotion }\end{array}$ & $\begin{array}{l}\text { Is Process } \\
\text { Continusus } \\
\text { or } \\
\text { Befch }\end{array}$ & $\begin{array}{l}\text { Typo Inpui } \\
\text { or Row } \\
\text { Motoriol. } \\
\text { usod }\end{array}$ & $\begin{array}{l}\text { Maximum } \\
\text { Quantity Input } \\
\text { por thor } \\
\text { (spocity unils) }\end{array}$ & $\begin{array}{c}\text { Type } \\
\text { of } \\
\text { Products*k }\end{array}$ & $\begin{array}{l}\text { Moximum } \\
\text { Quontily Oulput } \\
\text { por Hour } \\
\text { (specify unils) }\end{array}$ & $\begin{array}{c}\text { Averoge Quentily } \\
\text { Outpul } \\
\text { por Yoer } \\
\text { (specily unils) }\end{array}$ \\
\hline $\begin{array}{l}\text { Section } \\
4.5 \\
\text { sisions } \\
\text { ventory }\end{array}$ & $\begin{array}{c}\text { See Section } \\
4.2, \\
\text { Area Process } \\
\text { Descriptions }\end{array}$ & Cont inuous* & $\begin{array}{c}\text { Air } \\
\text { (including } \\
\text { moisture) }\end{array}$ & $537,087 \mathrm{lb} / \mathrm{hr}$ & $\begin{array}{l}\mathrm{O}_{2} \\
\mathrm{~N}_{2}\end{array}$ & $\begin{array}{l}116,667 \mathrm{lb} / \mathrm{hr} \\
115,9751 \mathrm{~b} / \mathrm{hr}\end{array}$ & $\begin{array}{l}459,261 \text { tons/year } * \star \star \\
462,001 \text { tons/year } * \star \star \\
\cdot \\
\star \star \star 330 \text { days/year }\end{array}$ \\
\hline
\end{tabular}

* Process is continuous, but venting of hydrocarbon adsorbers occurs intermittently, once per week for 8 hours.

** Not Included are vents and streams to treatment (See External Materfal Balance In Sect1on 4.2, Area Process Rescriptions).

4. Equipu.int usod in eoch procoss or oporatlon

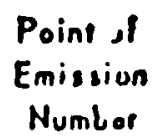

Point of

Numlor

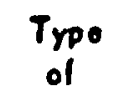

Equipmont

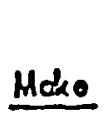

Modol .

Number
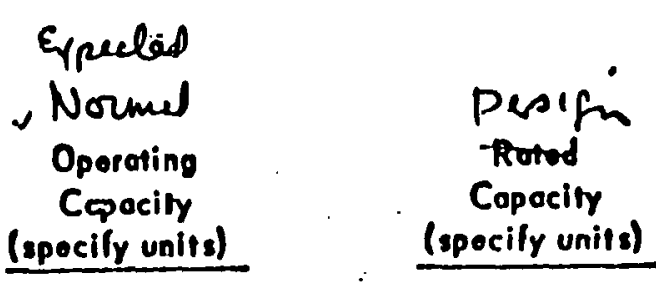

Date

Installed

NOT A P P.L I C A B L E 
Alr Separpation Unit

Cryogentic Systems - Area 14

\section{MANUFACTURING OR PROCESSING OPERATIONS (cont'd)}

Lo8

$\because \because:$

3. Fual une and equipment lop process hoot excluding hoot suppliod by Indirect hact exchongor (See Form No. APC I10A for Indirect heot oxchengora)

\begin{tabular}{|c|c|c|c|}
\hline $\begin{array}{l}\text { Point } \\
\text { of } \\
\text { Emlscion } \\
\text { Numbe }\end{array}$ & $\begin{array}{l}\text { Trpe } \\
\text { of } \\
\text { Fual }\end{array}$ & $\begin{array}{l}\text { Fud Usoge } \\
\text { Quenily } \\
\text { (spoelly unlis) }\end{array}$ & $\begin{array}{c}\text { Rotod } \\
\text { Bumos } \\
\text { Copecity } \\
\text { (BTU/Hour }\end{array}$ \\
\hline
\end{tabular}

Percent
Sullur

Percent

Alr Polluilon

Ash

Coofrol Equlpment

Conliol Elfielency by Porcent Woight and Boris for Eslimete

Not App11cab1e

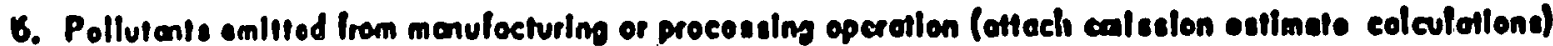

\begin{tabular}{|c|c|c|c|c|c|c|}
\hline $\begin{array}{l}\text { Polint } \\
\text { of } \\
\text { Emiorion } \\
\text { Numbor }\end{array}$ & $\begin{array}{c}\text { Pollutent } \\
\text { None } \\
\end{array}$ & $\begin{array}{l}\text { Chemical } \\
\text { Composition } \\
\end{array}$ & $\begin{array}{c}\text { Inlot } \\
\text { Looding } \\
\text { (oraind/SCF) }\end{array}$ & $\begin{array}{c}\text { Outlot } \\
\text { Looding } \\
\text { (oroind/SCF) }\end{array}$ & $\begin{array}{r}\text { Amount } \\
\text { Poune }\end{array}$ & $\begin{array}{l}\text { Emitied } \\
\text { Mour }\end{array}$ \\
\hline $4-V A-05$ & $\begin{array}{l}\mathrm{N}_{2} * \text { containing } \\
<100 \text { ppm of } \\
\text { hydrocarbons } \\
\text { originating from } \\
\text { ambient atmos- } \\
\text { phere. }\end{array}$ & $\begin{array}{l}\mathrm{N}_{2}{ }^{*} \text { containing } \\
<100 \text { ppm of } \\
\text { hydrocarbons } \\
\text { or } 1 \text { inating from } \\
\text { amb1ent atmos- } \\
\text { phere. }\end{array}$ & Not App11cable. & Not App11cab1e. & $\begin{array}{l}2463 \\
0.24\end{array}$ & $\begin{array}{l}\mathrm{N}_{2} * \\
11 . \mathrm{C}\end{array}$ \\
\hline
\end{tabular}

* $\mathrm{N}_{2}$ itself is not a pollutant. 
T. Dencribe lloroge and treneportotion of processed and row moterials and roloted ale pollution control moosures.

Raw materials from ambient atmosphere.

Storage of 02 and $\mathrm{N}_{2}$ in cryogenic tanks with no emission of pollutants to atmosphere.

Products exit process area via closed pipelines.

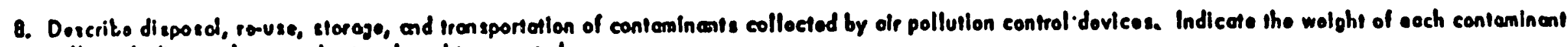

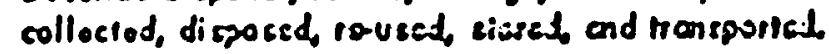

Not Applicable.

9. Ssbmit o Procoss Flow Diajren. Labal: (1) input of row motorlals, (2) produetion processes, process fuel combustlon, process equipment and als pollution control equipanent, and (J) all numbored colnts of emlssion of alr centaminente.

Process flow sheets are Included in Section 4.3.

See Drawing 00-14-0400 ID 
llydrogen Purification Intt Cryogenic Systems - Area 14

\section{DFPARTMENT FOR}

NATURAL RESOURCES AND

ENV IRONHENT AL PROTECTION

OIVISION OF AIR POLLUTION

FRAIJK FORT. KENTUCKY 40601

MANUFACTURING OR PROCESSING OPERATIONS

1. Normal Schodul of Opiciotion

A Houre por doy

24

D. Pods profuction sooson. (elrcle ono) (1) sioody yoor round
8. Doye por woek

7
C. Wooks per yoor

(3) foll (4) winter. (5) upring

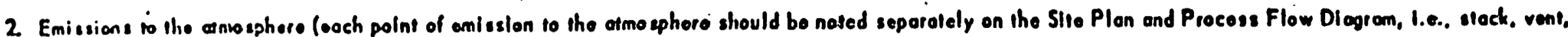
ard other points of di scliargo to the ofmosphore).

\begin{tabular}{|c|c|c|}
\hline $\begin{array}{l}\text { Poini } \\
\text { ol } \\
\text { Enioilon } \\
\text { llumbor }\end{array}$ & $\begin{array}{l}\text { Hoight } \\
\text { of } \\
\text { Rolcase } \\
\text { ifost) }\end{array}$ & $\begin{array}{c}\text { Dienolor } \\
\text { of } \\
\text { Siode ce Vont } \\
\text { (feil) }\end{array}$ \\
\hline $14-V F-12$ & $\begin{array}{l}\text { Facility } \\
\text { Flare }\end{array}$ & $\begin{array}{l}\text { Fac111ty } \\
\text { Flare }\end{array}$ \\
\hline
\end{tabular}

\begin{tabular}{l} 
Quenitity of \\
Gases: \\
Dischergod* \\
\hline (ocfin)
\end{tabular}

\begin{tabular}{|c|c|}
\hline $\begin{array}{l}\text { Temporoture } \\
\text { of Gasos } \\
\text { Dl schargodt } \\
(\circ)\end{array}$ & $\begin{array}{c}\text { Type of } \\
\text { Air Pollution } \\
\text { Conirol } \\
\text { Equlpmont }\end{array}$ \\
\hline Amblent & $\begin{array}{c}\text { Facility } \\
\text { Flare }\end{array}$ \\
\hline
\end{tabular}

D-9

Ineinolod

Not App11cab1e

\section{Conirol Elfieloney by Percent Ylolghi and Bosic for Eolimote (olficioncy baale)}

Approximately $100 \%$ after flaring, based on standard combust Ion calculations.

* To flare. 
3. Monuliceturing or Processing Unils (list oll procouses or operotions)

\begin{tabular}{|c|c|c|}
\hline $\begin{array}{l}\text { Point } \\
\text { of } \\
\text { Emission } \\
\text { Numbire }\end{array}$ & $\begin{array}{c}\text { Trpe of } \\
\text { Procees } \\
\text { or } \\
\text { Operotion }\end{array}$ & $\begin{array}{c}\text { la Procese } \\
\text { Confinuses: } \\
\text { of } \\
\text { Botch }\end{array}$ \\
\hline $\begin{array}{l}\text { e Section } \\
4.5, \\
\text { issions } \\
\text { iventory }\end{array}$ & $\begin{array}{l}\text { See Section } \\
4.2 \text {, Area } \\
\text { Process De- } \\
\text { scriptions }\end{array}$ & Cont Inuous \\
\hline
\end{tabular}

* Not included are vents and st reams to
4. Equlpu.int ueod in eoch procoss or oporatlon

1. Equipu.
Point of

Emission Numb or

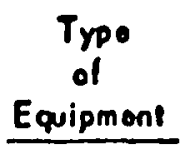

Typo Inpul or Row

Matorials

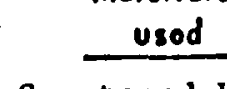

Sweetened H:P : Feedgas

Fue1 from LPG Recovery

Medium Pressure Steam

Compressor

Crankcase/

Distance

pieces surge

$\mathrm{N}_{2}$ gas

\begin{tabular}{|c|c|c|c|}
\hline $\begin{array}{c}\text { Moximum } \\
\text { Quonity Inpus } \\
\text { por Hour } \\
\text { (apocify unils) }\end{array}$ & $\begin{array}{c}\text { Typo } \\
\text { of } \\
\text { Products } \\
\end{array}$ & $\begin{array}{c}\text { Maximum } \\
\text { Quantity Oulpul } \\
\text { por Hour } \\
\text { (specify unite) }\end{array}$ & $\begin{array}{c}\text { Avoroge Quentioy } \\
\text { Oulput } \\
\text { por Yoor } \\
\text { (specily unite) }\end{array}$ \\
\hline $72,7091 \mathrm{~b} / \mathrm{hr}$ & $\begin{array}{l}\text { Liquid } \\
\text { Aromatics }\end{array}$ & $1,1631 \mathrm{~b} / \mathrm{hr}$ & 4,605 tons/year*t \\
\hline $7,550: 1 \mathrm{~b} / \mathrm{hr}$ & $\begin{array}{l}\text { Cold Box } \mathrm{H}_{2} \\
\text { to Compressor } \\
\text { Unit }\end{array}$ & $32,0841 \mathrm{~b} / \mathrm{hr}$ & 127,053 tons/year ** \\
\hline \multirow{2}{*}{$21 \mathrm{~b} / \mathrm{hr}$} & $\begin{array}{l}\text { Cold Pox Fuel } \\
\text { to LPG Re- } \\
\text { covery }\end{array}$ & $33,000 \mathrm{lb} / \mathrm{hr}$ & 130,680 tons/year $\star \star$ \\
\hline & $\begin{array}{l}\text { Fuel to SRC- } \\
\text { l Facility }\end{array}$ & 10,448 & $\begin{array}{l}41,374 \text { tons/year ** } \\
* * 330 \text { days/year }\end{array}$ \\
\hline
\end{tabular}

Eppeliod Process Descriptions)

Normal

Oporoting

Capacity

(spocily units)

\section{pesifn \\ Rotod \\ Copocity}

(spocily unils)
Dote

Insiolled

NOT A P P L I C A B LE 
Hydrogen.,Purification Unit Cryogentc Systems - Area 14

\section{MANUFACTURING OR PROCESSING OPERATIONS (coni'd)}

Log

3. Fuol use and oquipment for process hoot excluding hoot suppliod by Indirect hoot oxchanger (See Form No. APC IIOA for indirect hoot exchongera)

\begin{tabular}{|c|c|c|c|}
\hline $\begin{array}{l}\text { Point } \\
\text { ol } \\
\text { Emisuion } \\
\text { Number }\end{array}$ & $\begin{array}{l}\text { Troe } \\
\text { of } \\
\text { Fuel }\end{array}$ & $\begin{array}{l}\text { Fud Usoge } \\
\text { Quentify hlour } \\
\text { (epoelly unlis) }\end{array}$ & $\begin{array}{l}\text { Rotod } \\
\text { Bumar } \\
\text { Copecity } \\
\text { (BTU/Hour) }\end{array}$ \\
\hline
\end{tabular}

Rotod

Copecity

\section{Pereent \\ Sullur}

\begin{tabular}{cc} 
Type of \\
Percent & Alr Polluilon \\
Ash & Cosirol Equipment \\
\hline
\end{tabular}

Control Efficlency by Porcenl Woight and Basis for Earimete (ollicioncy botid)

Not Applicable

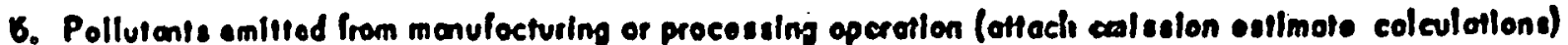

\begin{tabular}{|c|c|}
\hline $\begin{array}{l}\text { Poline } \\
\text { of } \\
\text { Emisuion } \\
\text { Numbor }\end{array}$ & $\begin{array}{c}\text { Pollutant } \\
\text { Nome }\end{array}$ \\
\hline $14-V F-12$ & $\begin{array}{l}\mathrm{H}_{2}{ }^{\star} \\
\mathrm{N}_{2}{ }^{\star} \\
\mathrm{Ar}^{\star} \\
\mathrm{CO} \\
\mathrm{C}_{1} \\
\mathrm{C}_{2} \\
\mathrm{C}_{3} \\
\mathrm{C}_{4} \\
\mathrm{C}_{5} \\
\mathrm{C}_{6}{ }^{+}\end{array}$ \\
\hline
\end{tabular}

\begin{tabular}{|c|c|c|}
\hline $\begin{array}{l}\text { Chemleal ** } \\
\text { Composillon }\end{array}$ & 6 & $\begin{array}{l}\text { Inlst } \\
\text { Looding } \\
\text { raind/SCF }\end{array}$ \\
\hline $\mathrm{H}_{2}$ & not & app11cable \\
\hline $\mathrm{N}_{2}$ & & \\
\hline Ar & · & \\
\hline CO & . & \\
\hline$c_{1}$ & & \\
\hline $\mathrm{C}_{2}$ & & . \\
\hline $\mathrm{C}_{3}$ & & \\
\hline $\mathrm{C}_{4}$ & . & \\
\hline $\mathrm{C}_{5}$ & & \\
\hline $\mathrm{C}_{6}+$ & & \\
\hline
\end{tabular}

$\frac{\begin{array}{c}\text { Ouflos } \\ \text { Looding } \\ \text { (oraind/SCF) }\end{array}}{\text { not app1icable }}$

Amount Emitiod Poundel Hour

0.1 material balance

* Not pollutants.

$\star *$ To flare, after flaring 'stream cons1sts of $\mathrm{CO}_{2}$ and $\mathrm{H}_{2} \mathrm{O}$ in $\mathrm{N}_{2}$ and $\mathrm{Ar}$. 


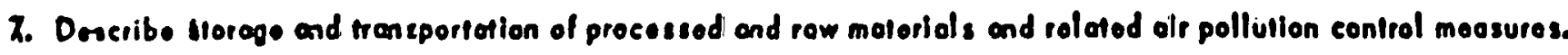

Raw materials and products enter/exit via closed pipelines. Waste gases are sent to facility flare.

8. Descrite di sposd, ro-use, storege, and tren sportetion of contarainants collected by air pollution confrol dovices. Indicate the wolght of each contarninent

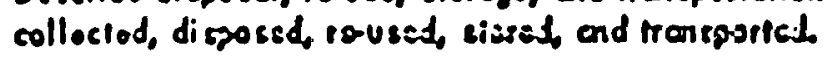

Not applicable. Waste gases sent to fac1lity flare.

9. Ssbrnit o Process Flow Diagran. Labol: (I) Input of row motorials, (2) productlon processes, process fuel combustlon, procoss equipment and air pollution control equipnent, and (3) oll numbered points of emission of air centeminents.

Process flow. sheets are Included In Section 4.3.

See Drawing 00-14-0400 2D 
MANUFACTURING OR PROCESSING; OPERATIONS

1. Nermal Schodule of Oportion

A Hoverpor do 24

D. Pocts rofuction soozon (elrelo ond
B. Doyoper year

330

C. Heoks por yocr

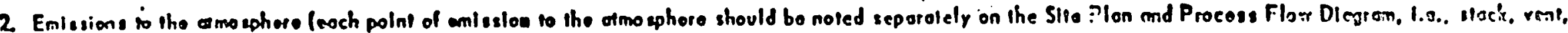

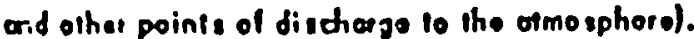

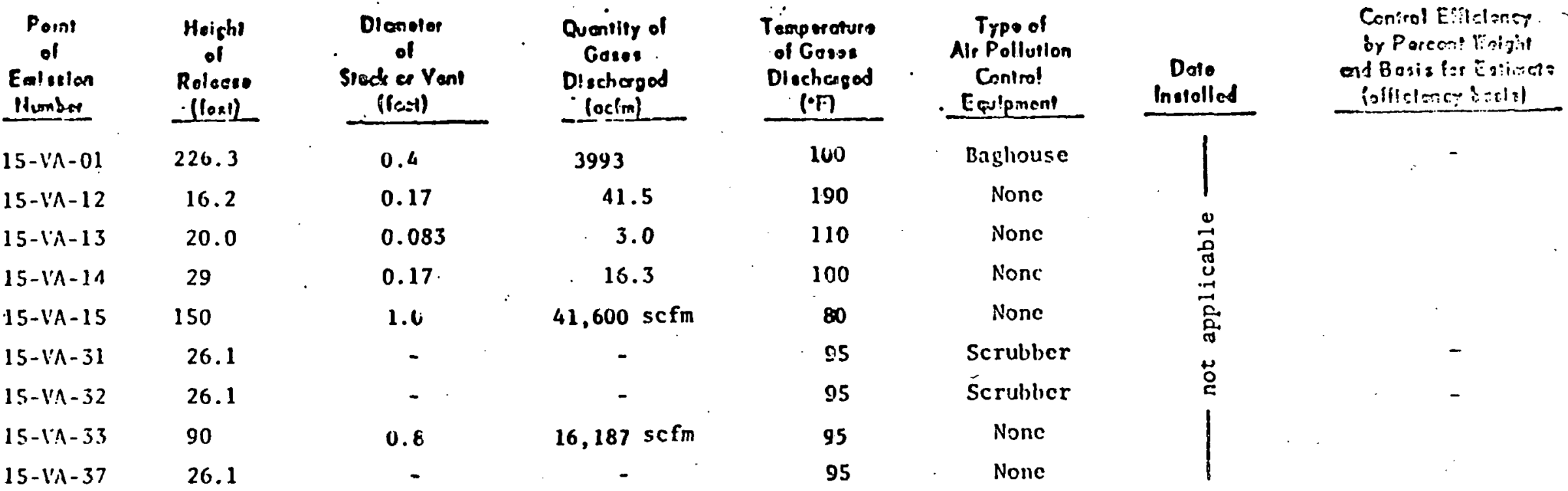

$-=$ not yet available 
3. Monulicturing or Procossing Unirs (list all processos or oporations)

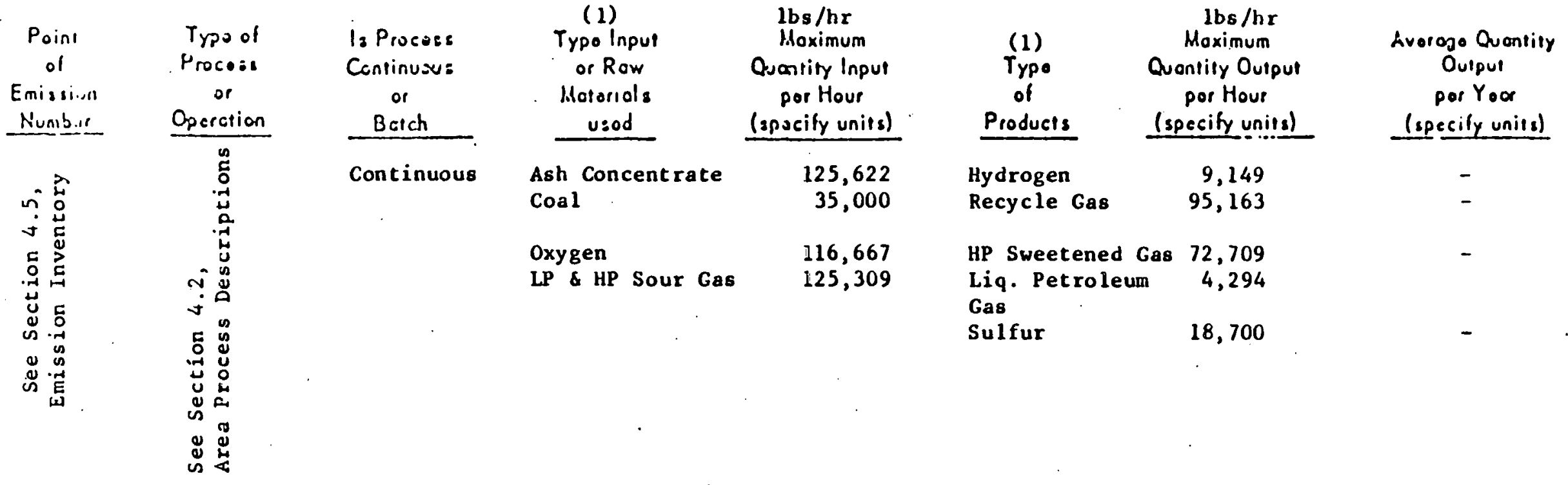

1. Equipe. int usst in ooch procoss or of oration

Point of
Emission
Numlor

15-VA-01

$15-V A-31$

is-VA-32

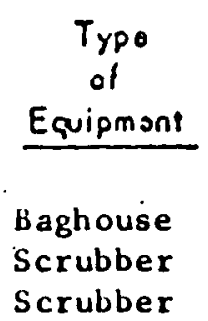

$$
\begin{aligned}
& \text { Ép:cG.1 } \\
& \text { No:m: } \\
& \text { Oporating } \\
& \text { Copacity }
\end{aligned}
$$

Numbor

(spocify units)

Data will be furniahed when available--

\section{Doto}

Installed

\section{Not applicable}

Not applicable

Not applicable

(1) For more complete list see section 4.4 "Materials Balances". 
GAS SYSTLRIS

AREA 15

MANUFACTURING OR PROCESSIHG OPERATIONS (EONI'd)

Les

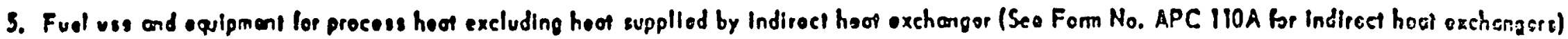

\begin{tabular}{|c|c|c|c|c|c|c|c|}
\hline $\begin{array}{l}\text { Point } \\
\text { of } \\
\text { Escinsion } \\
\text { Nurnore }\end{array}$ & $\begin{array}{l}\text { Trpo } \\
\text { of } \\
\text { Fuol }\end{array}$ & $\begin{array}{l}\text { Fual Usoge } \\
\text { Quanlliy Niour } \\
\text { (epoelly urilia) }\end{array}$ & $\begin{array}{l}\text { Rotod } \\
\text { Burner } \\
\text { Copecin } \\
\text { (BTUNiour) }\end{array}$ & $\begin{array}{l}\text { Percent } \\
\text { Sullur }\end{array}$ & $\begin{array}{c}\text { Porcont } \\
\text { Ash }\end{array}$ & $\begin{array}{c}\text { Trpo of } \\
\text { Ale Pollution } \\
\text { Cartrol Esulpmen: }\end{array}$ & 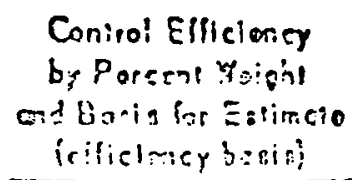 \\
\hline
\end{tabular}

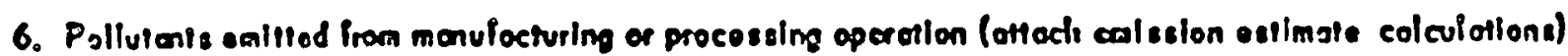

\begin{tabular}{|c|c|c|c|c|c|}
\hline $\begin{array}{c}\text { Poins } \\
\text { of } \\
\text { Emigrion } \\
\text { Number }\end{array}$ & $\begin{array}{c}\text { Pollutane } \\
\text { Nome } \\
\end{array}$ & $\begin{array}{l}\text { Chemical } \\
\text { Composillion }\end{array}$ & $\begin{array}{c}\text { Inlst } \\
\text { Looding } \\
\text { (nroins/SCF) }\end{array}$ & $\begin{array}{c}\text { Ourlat } \\
\text { Looding } \\
\text { (oroinz/SCF) }\end{array}$ & $\begin{array}{l}\text { Amount Emlitod } \\
\text { Pound Ml Hou: }\end{array}$ \\
\hline $15-V A-01$ & Particulates & Coal Particles & - & 0.01 & 0.2 \\
\hline $15-V A-12$ & $\begin{array}{l}\text { Co } \\
\text { voc }\end{array}$ & - & - & - & $\begin{array}{l}2.95 \times 10^{-4} \\
1.17 \times 10^{-3}\end{array}$ \\
\hline $15-6 A-13$ & $\begin{array}{l}\mathrm{CO} \\
Y \mathrm{OC}\end{array}$ & - & - & - & $\begin{array}{l}2.16 \times 10^{-5} \\
6.00 \times 10^{-3}\end{array}$ \\
\hline
\end{tabular}


GAS SYSTERS

AREA 15

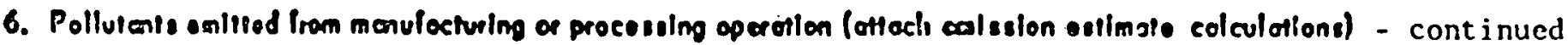

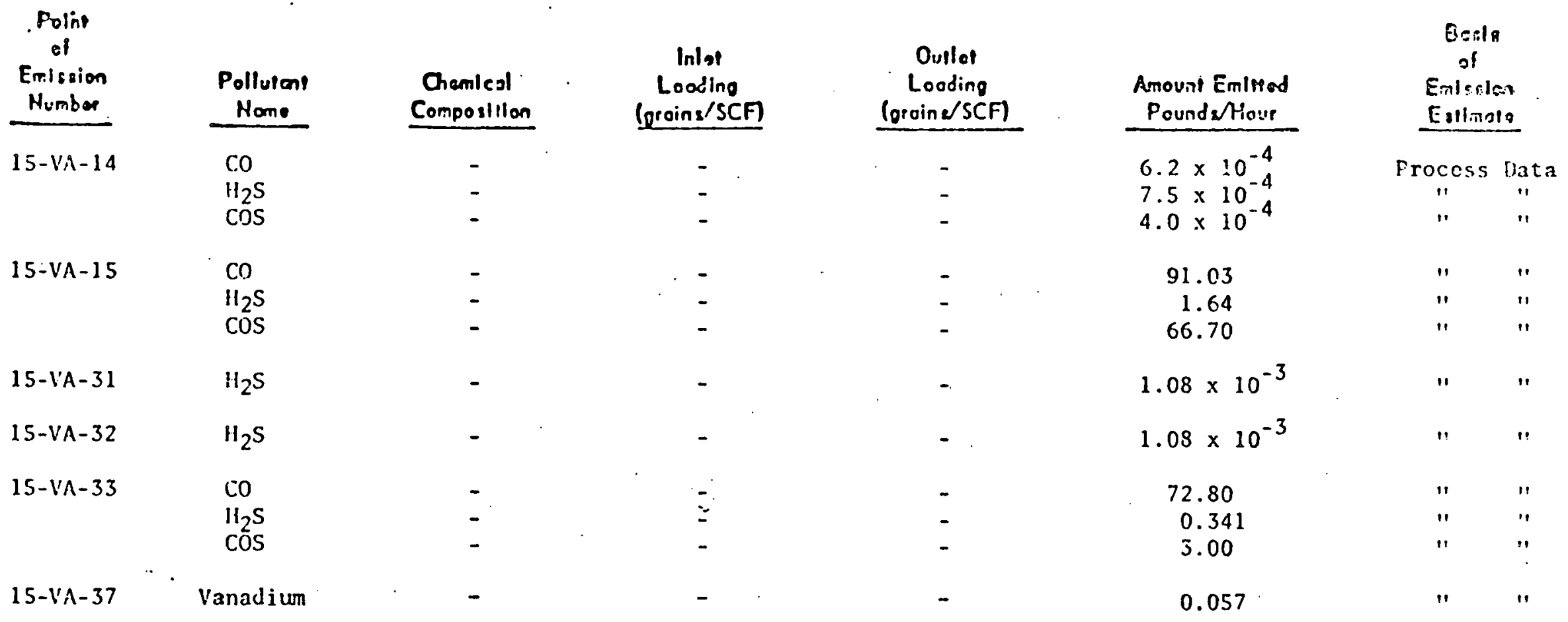




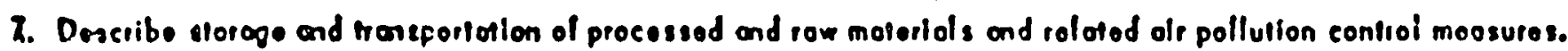

Not applicable

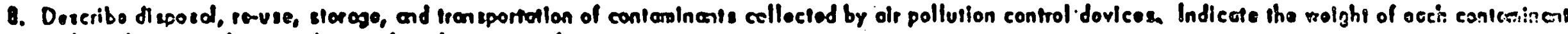

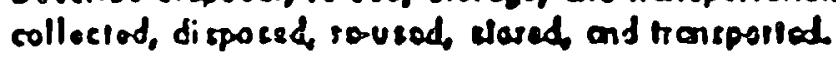

Not yet available

9. Subnit o Process Flow Diagran. Labsl: (1) Input of row motorials, (2) production procosses, process fuel combustlon, procoss equipsomi end air pollution

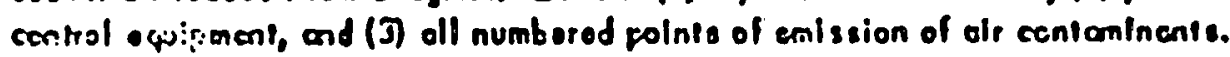

Sec Section 4. 3, Environmental Process Flow Diagrams 
DEPARTMENT FOR

NATURAL RESOURCES AND

ENV IRONAENTAL PROTECTION

OIVISION OF AIR POLLUTION

FRANKFORT. KENTUCKY 40601

INCINERATORS AND/OR WASTE BURNERS

Polns of Emission Number 12-VA-05

This section must be comploted for any apparatus used to ignite and bum solid, liquid or goseous combustible wastes. liems 1, 2, 3, and 4 are design eriterie on the incinerator manufocturer' s name plote. The name plote should be in o conspicuous plase on the incinerator.

1. Monufocturep's Name Not Yet Available

2. Model Number Not Yet Available

3. Roted Copocity Not Yet Available. por hour, or rons por hour
4. Type of Wasto:
123
4
(5) 6 (Circle Type)

5. Typo: 1). Incinerotor, Singlo Ohamber [X] Multiple Chamber

2). Waste Burner (toepeo, truncoted cone, silo, other) Vent Waste Incinerator

6. Are instruetions for the operation of the incinereter posted in a conspicuous ploce neas the incinerater? Yes $\square$ No $\square$ Not applicable - New installation

7. Quantity of wasto bumod (s.g., tons/yoew, eubic youds/day, pounds/hous 66.4 (Circle approptlete units)

8. Operation schedule:

Hours per doy
Woaks por yea

9. Type of waste bumed:

Pepór

Cordboard

Wood

Plastic

(Indicote Chomical Composition)

Rubber

(Indicete Chemicol Composition)

Corbage

Pothological Weste

Goseovs Liquid, or Somi-liquid wostes

(Indicate Chemicol Composition)

incombustibles

Other (Specify)
Doys per wouk Othor 8 days/year.

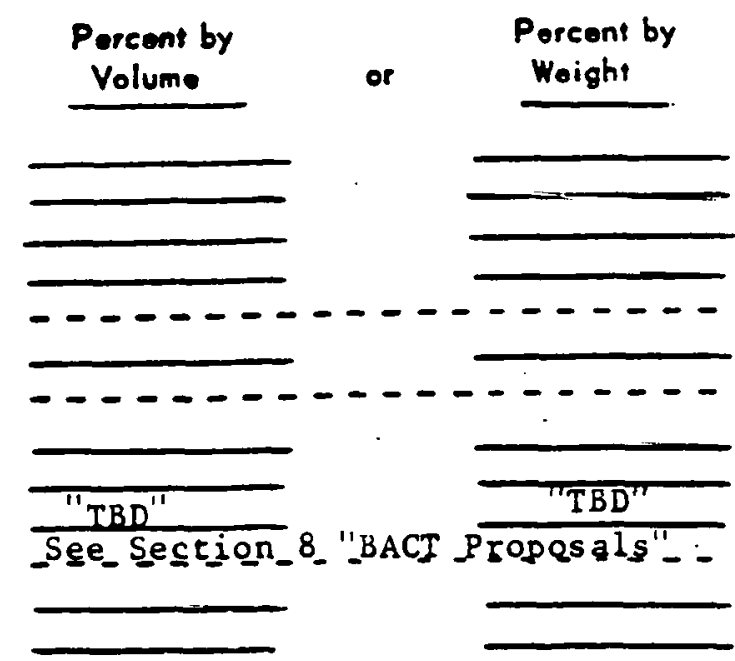

10. Photogroph of unit-melose o minimum size phologroph of $5^{\prime \prime} \times 7^{\prime \prime}$.

Not applicable - New Installation

11. Pla of the unit - monufacturer's drowing of drawing clearly lllustroting oll dimensions and construction details must be submitted.

"Manufacturers drawings are not yet available, but will be furnished as soon as possible". 


\section{INCINERATORS AND/OR YAST'E BURNERS (cont'd)}

12. Combustion Air Not yet available

(a) Droft

Natural Drati $\square$

Induced Drafi

in. $\mathrm{H}_{2} \mathrm{O}$

(b) Air Disiribution Not yet available.

No. of Ports

Port Sizo (sq. in.)

Air Flow (SCFM)

13. Stack

(a) Inside diometor 30

inchos

(b) Height obove grates to top of stoek 150 foot

(c) Height of stock obove any building or obstocle within 25 foet of the incinerctor Not appilicable foes

(d) Spork Arrestor. Height not applicablenches Serooning oponings antapplicablenchos

(d) Stock Shell Not yet available

Type of moterial and thickness

Type of refrociory, thickness and remperature rating

14. Shell Construction Not yet available

(a) Typo of moteriol and thickness

(b) Typo of insulation and thickness

(c) Typo of refractory. thickness and remporature rating

(d) Type of soams

(o) Mathod used to tie rofractory to outside sholl

15. Auxiliary Equipmont
(o) Domper:
Barometric $\square \quad$ Gulllotine
None
Not yet available
(b) Primary bumer (combustion chamber)
Fual Process Fuel 0 il
BTU hour roting HHV-19,130 BTU/Lb, LHV-17,262 BTU/Ib
(c) Socondory burner
Fuel Not apolicable
BTU/hour roting
(d) Other (Specify)

16. Control Equipmont Not applicable

(a) Afterburnor on stock exir $\square$ Typo

(b) Serubber $\square \quad$ Typo

(c) Other (Specity)

17. Rogulation Complianco Not applicable - New installation

(a) Hove stack tests been performod on the unit? Yes $\square$ No $\square$

(b) Are the results of the stack lests anclosod and made a part of this permit application? Yos $\square$ No

(c) Ara the results of the stock tests on file in the Commission office? Yos $\square$ No 
Point of Emission Number 13-VA-3

This section must be comploted for any aporatus used to ignite and burn solid, liquid or gossous combustible wostes. Items 1, 2, 3, and 4 are design eriterio on the incinerator menufocturer's name plate. The name plote should be in a conspicuous plase on the incinerater.

1. Monufocturer's Nome Not vet available

2. Hodel Number Not yet available

3. Rotod Copocity Not yet availablefb. por hour, or rons per hour
4. Type of Wost

$\begin{array}{llll}0 & 1 & 2 & 3\end{array}$
4
4. 5
5 (Circle Typo)

5. Trpe:
1)
Multiple Chamber $\square$ TBD

2). Waste Burner (10epeo, muncated cone, silo, other) Rotary Ki In

6. Are instructions for the operation of the incinerator posted in a conspicuous ploce near the incinerator? Y.: $\square$ No $\square$ Not applicable to new installation

7. Quantity of weste bumed (..9., ton $\sqrt{ } /$ yea, cubic yord $/$ doy, pounds/houl) 4800 (Circle oppropriate units)

8. Operation schedule:

Hours por doy $\frac{24}{47.0}$ Woaks per yoor
Worh
Doys por wadk Orher

9. Type of woste bumed:

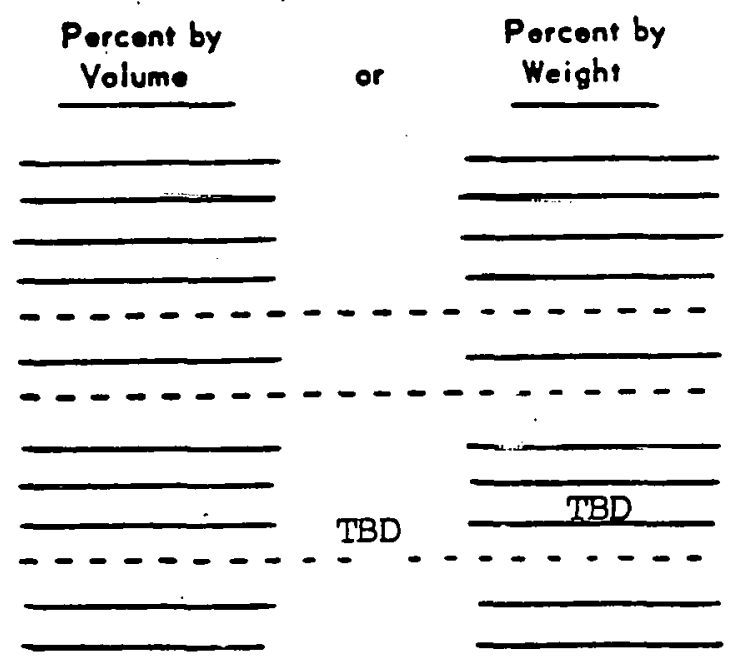

10. Photogreph of unit_enclose o minimum sizs photogoph of $5^{\prime \prime} \times 7^{\prime \prime}$. Not applicable to new installations

11. Plon of the unit - nonufartus or's deowing of drawing eleaply lllustroting all dimensions and construction detoils must be aubmittod.

Not yet available, but will be fumished as soon as available. 
12. Combustion Air TBD
(a) Droft
Natural Drafi $\square$
Pressure
Induced Draft
- in. $\mathrm{H}_{2} \mathrm{O}$
Foreed Oroit

(b) A,r Distribution TBD

Overfire Underfire Secondory

No. of Ports

Port Sizo (sq. in.)

Air Flow (SCFM)

13. Stock NOT APPLICABLE
(a) Inside dicmetor inches
(b) Heighr obove grates to top of stock
(c) Height of stack above any building or obstocle within 25 foet of the incinerator
(d) Spork Arresior. Heighi
(e) Stack Shell inches Screening openings
Type of material and hiekness
Type of refroctory, thickness and temporature raing feer

14. Shell Construction TBD

(a) Type of material and thickness

(b) Type of insulation and thickness

(c) Type of refractory, thickness and temper oture rating

(d) Typo of sooms

(o) Mothod used to the rafroctory to outside shall

15. Auxiliory Equipment TBD
(a) Domper
Boromotric $\square$
Guillotine
None
(b) Primary burner (combustion chamber)
Fuol
BTU hour sating
(c) Secondary burner
Fuel
BTU/hour roting
(d) Oiher (Specify)

16. Conirol Equipmont
(a) Afferburnep on stock oxit
(b) Scrubber $\mathrm{x}$
(c) Opher (Spocity)
Type
Typo Venturi Scrubber

17. Regulation Compliance NOT YET AVAITABLE
(a) Have stack tests beon porformed on the unit?
(b) Are the cesults of the stack tests enclosed and made a port of this pormit application? Yos $\square$ No $\square$

(c) Are the cosulte of the stack tosts on file in the Commission office? Yos $\square$ No $\square$ 
OEPARTMENT FOR

NATLRAL REJOURCES ANO

$\log$

ENV JROIHAEATAL PROTECTICN

OIVISION CF AIR POLLUTION

FRANKFORT, KENTUCKY 40001

INCINERATORS AND/OR IYASTE BURNERS

Polnt of Emission Number 15-VA-04

This section must to completed for any aporatus usod to ignite end burn solid, liquid or gosoous combustible wastes. liems 1, 2, 3, and 4 are dosign eriserio an tho ineinorator menufacturer's nane plate. The neme plate should to in a conspicuous plose on the incinorotop.

1. Monulactur or's Name

Not yet available

2. Hodel Number

Not yet available 1......... -

3. Roted Copocity Ib. per hour, or tons par houe

TBD

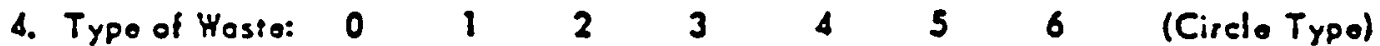

5. Typo: 11. Incinerotor, Singlo Chember $\square$ Multiplo Chamber

2). Wosto Burner (10epoo, truncorod cono, silo, other) Gasifier Startup Flare

6. Aro instructions for the operation of the incinorctor posted in a conspicuous ploce noer the incinerctor? Yos $\square \quad$ No $\square$ NA New Installation

7. Quantity of weste bumed (0.9., ton $/$ yoar, cubie yords/doy, poundshour)

TBB (Circlo appropriote units)

8. Operation schoduie:

Hours por doy
Hooks por yeer

9. Typo of wasto burnod:

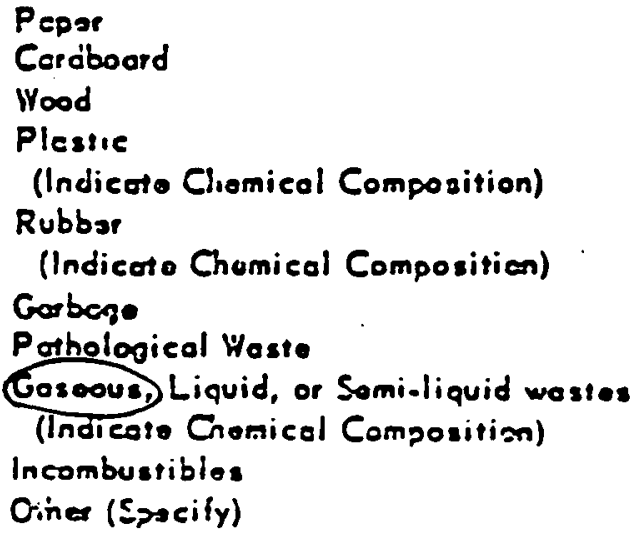

Doys por wook Othor Startups

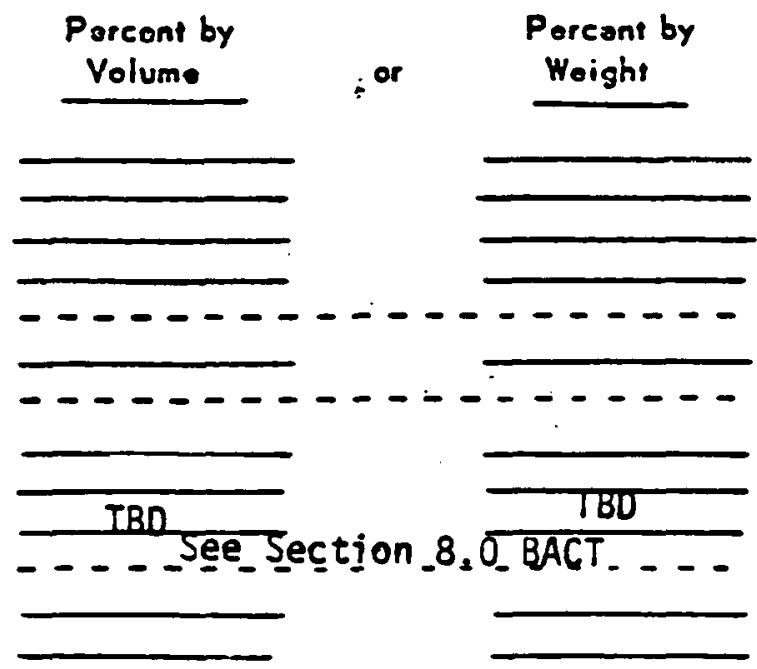

10. Photogeopin of unit-onclose o minimum siz= photogroph of $5^{\circ} \times 7 \%$. NA New Installation

11. Plen of the unit -- manutarus or's drowing or drewing clearly illustreting ell dimonsions and construction deisils must be submitiod.

ilot available yet, however, will be provided as soon as possible. 


\section{INCINERATCRS AND/OR WAST' BURNERS (cont'd)}

12. Combustion Air TBD
(o) Droit
Noiural Drait
Inducod Droft
- in. $\mathrm{H}_{2} \mathrm{O}$
Pressure

TBD

(b) Air Distribution

\section{Ovorfiro}

No. of Ports

Pors Sizo (sq. in.)

Air Flow (SCFM)
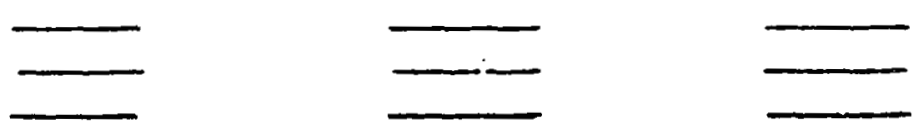

13. Stock

TBD

(a) Inside dicmetor

inchos

(b) Height obove grates to top of stack foot

(c) Herght of stock above any building or obstoclo within 25 feot of the incinerctor

(d) Spcrk Arrestor. Height inchos

Screening oponings Peor

(e) Stock Shell

Type of material and thickness

Type of refroctory, thickness ond temporoture rating

14. Sholl Construction TBD

(a) Typo of material and thickness

(b) Type of insulation and thickness

(c) Typo of refrectory, thicknoss and remperoture roting

(d) Type of seans

(a) Mothod used to the refractory to outsido shall

15. Auxiliogy Equipment TBD
(a) Domper:
Bcrometric $\square$
(b) Primary burner (combustion chambor)
Guillotine $\square$ None $\square$
Fuol
BTU hour sating
(c) Socondary burner
Fuel
BTU/hour roting
(d) Other (Specify)

16. Control Equipmont NA
(a) Afterburnar on stack exit
(b) Serubber $\square$
(c) Othar (Specity)
Typo
Typo

17. Rogulation Complianca NA

(a) Hove stock tests beon portormed on the unit? Yos $\square$ No $\square$

(b) Are the cesults of the stack lasts anclosod and modo o port of this pormit opplication? Yas $\square$ No $\square$

(c) Zira the results of the stock tests on filo in the Commission office? Yos $\square$ No $\square$ 
ENV JRONAENTAL PROTECTION

DIVISION CF AIR POLLUTION

FRANKFORT . KENTUCKY 40601

INCINERATORS AND/OR WASTE BURNERS

Point of Emission Number 15-VA-05

This section must be comploted for any gporatus usod to ignito and bum solid, liquid or gasoous combustible wastes. liems $1,2,3$, and 4 are design eriferia on the incinerator monufocturer's name plate. The name plate should be in a conspicuous plase on the incinerator.

1. Monufocturer's Name Not vet available

2 Model Number Not yet available

Eisuren

3. Rotod Copecity Ib. per hour, or fons por hour

0.86 MM BTU/HR

4. Type of Woste: 123 4 (5) 6 (Circle Typo)

5. Typo: 1). Incinocotor, Single Chamber $\square]$ Mulriple Chember

2). Wosto Burner (100peo, truncated cone, silo, other) Pilot Flame

6. Are instruetions for the operation of the incinereter posted in a conspicuous place near the incineretor?
Yos
No
NA New Installation

7. Quantity of wosto bumed (e.g., tons/yoor, cubie yords/doy, pounds/hour)

817 SCF/HR

(Circle coprogriote units)

8. Operation sehoduite:

Hours por doy
Wouks por yoe

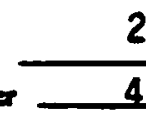

9. Type of wasto burnod:

Pepar
Cordboard
Yood
Plestic
(Indicato Chemical Composition)
Rubbar
(Indicato Chamical Composition)
Gorbege
Porhological Waste
Goseous Liquid, or Somialiquid wostes
(Indicato Cromical Composition)
Incombustibios
Oriner (Spacify)
Doys per wot Other

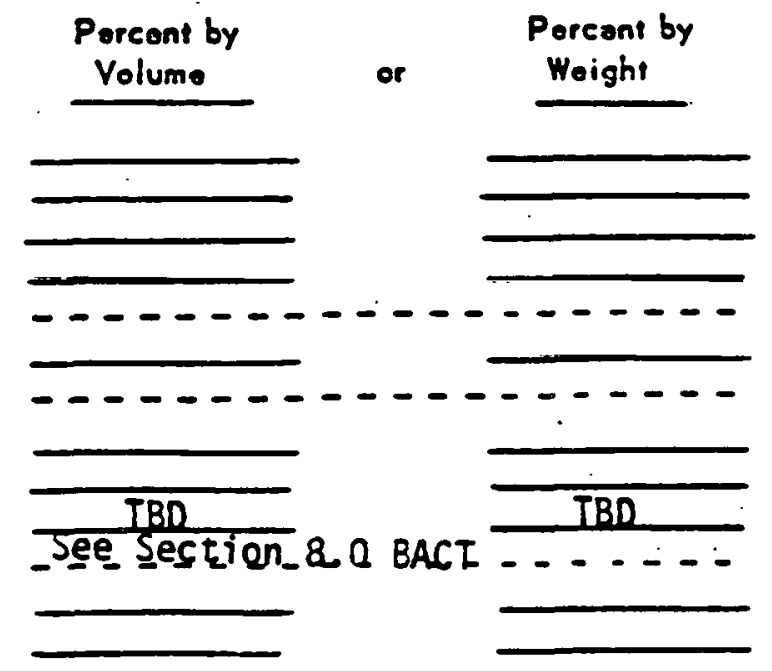

10. Photogroph of unit-onclose a minimum sizz pholosroph of $5^{\prime \prime} \times 7^{\prime \prime}$.

\section{NA New Installation}

11. Ples of the unit - manufocturor's drowing of drowing clscriy illustroting all dimensions and construction doreils must be cubmitrod.

Not yet available, however, will be furnished as soon as possible. 
12. Combustion Air TBD

(a) Drait

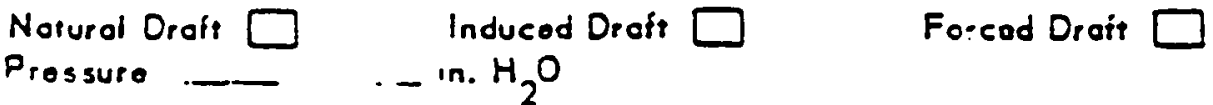

(b) Air Distribution

No. of Ports

Port Sizo (sq. in.)

Air Flow (SCFM)

\section{Ovorfire}

Undorfire

Socondory

13. Stoek TBD

(a) Inside diametor inchos

(b) Moight obove grotes to top of stock foot

(c) Height of stock above ony building or obstocle within 25 feot of the incinorator

(d) Spork Arrestor. Height inchos

Scroening openings foop

(e) Stack Shell

Type of moteriol and thicknoss

Type of rofroctory, thickness and tomporature rating

14. Sholl Construction TBD

(o) Typo of materiol and thicknoss

(b) Typo of insulation and thicknoss

(c) Typo of refractory, thicknoss and tompor oturo rating

(d) Type of sooms

(o) Mothod used to 110 rofractory to outsido shall

15. Auxiliory Equipment
(a) Damper:
Beromotric $\square$
Guillotino
Nono
(b) Primary burner (combustion chambor)
Fuol
Process Fuel Gas
BTUhour rating 800,000
(c) Socondory burner
Fuol
BTU/hour rating
NA
(d) Othor (Speciry)
TA

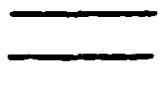

16. Conirol Equipmont NA
(a) Afierburnor on stack oxit
(b) Scrubber $\square$
(c) Oihar (Spocity)
Typo
Typo

17. Rogulation Complianco NA proposed installation
(o) Hovo stock tosts boon porformod on the unit?

\section{Yos}
No

(b) Are the results of the stack losts anclosod and mado a part of this purmit application? Yas

No

(c) Zi, the results of the stock tosts on filo in the Commission offica? Yos $\square$ No $\square$ 
This section must be completed for any aparatus used to ignite and bum solid, liquid or goscous combustiblo wastes. liems 1, 2, 3, and 4 are design criteria on the incinerotor manufacturer's name plate. The nome plate should be in a conspicuous ploce on the incinerotor.

1. Menufactur or's Name Not yet available

2 Hodol Numbor Not yet available Deangr

3. Rated Copecity Ib. per hour, or ions pop hour $23 \times 10^{6} \mathrm{BTU} / \mathrm{HR}$

4. Typo of Wasta: $0 \quad 1 \quad 2 \quad 3 \quad 3 \quad 4$ (5) 6 (Circle Typo)

5. Typo: 1). Ineinorotor, Single Chamber [] Multiple Chember

2). Wasto Burner (foepoe, truncated cono, silo, other) Thermal oxidizer

6. Are instructions for the operation of the incineretor posted in a conspicuous plece near the incinerotor? Yos $\square$ No $\square$ NA New Installation

7. Quantity of westo bumed (e.9., tona/yoor, eubie yorda/doy, pounds/hour) TBD (Circle copropricte units)

8. Operation schodula:

\section{Hours per doy Woaks por yoer}

9. Type of waste burmad:

Pepar

Cardboord

Yood

Plestic

(Indicate Chemical Composition)

Rubbar

(Indiceto Chomicol Composition)

Gorbege

Pahologienl Wosto

Gaseous, Liquid, ar Somi-liquid wastes (Indicoto Cromice! Composition)

Incombustibles

Orine (Epacify)
Doys por woek Other Startups \& Shutdowns

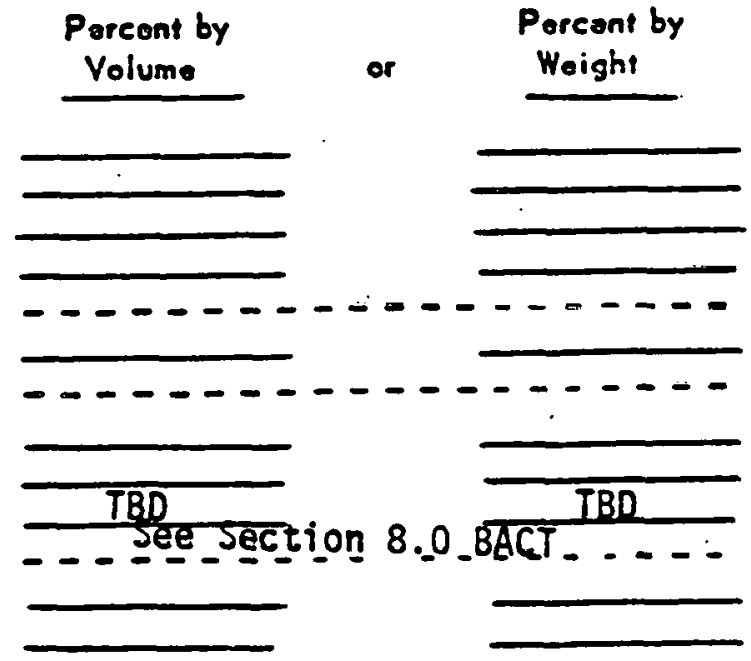

10. Photogroph of unit_onclose o minimum size phologroph of $5^{\prime \prime} \times 7^{\prime \prime}$.

NA New Installation

11. Ples of the unit - - manufactur or's drawing or drawing clecoly illustroting oll dimensions and construction detoils must be cubmittod.

Not yet available, however, will be furnished as soon as possible. 
12. Combustion Air TBD

(a) Draft

Natural Draft $\square \quad$ Induced Droft
Pressuro $\square-\mathrm{in}_{2} \mathrm{O}$

Forcod Droft $\square$

(b) Air Distribution TBD

Ovorfire Undnefies Socondory

No. of Ports

Port Sizo (sq. in.)

Air Flow (SCFM)
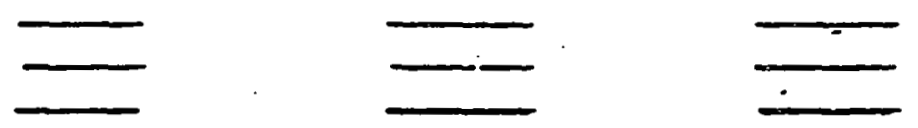

13. Stoek
(a) Inside diametor
inchos
(b) Height above grates to top of stock 150
(c) Herght of stock above any building or obstecle within 25 feot of the incinerctor
(d) Spork Arrestor. Height TBD inehos
Seroening oponings Poot
(e) Stock Shell TBO
Type of moterial and thickness
Type of refroctory, thickness ond tompercture roting

14. Shall Construction TBD
(a) Typo of materiol and thickness
(b) Typo of insulation and thickness
(c) Type of refractory. thickness and semper oture roting
(d) Type of seoms
(o) Mothod used to the cofroctory to outside shall

15. Auxiliogy Equipment TBD
(a) Damper:
Borometric $\square$
Guilloine $\square$
None $\square$
(b) Primory burner (combustion shombor)
Fuel
BTUhour rating
(c) Sacondary burnor
Fuol
BTU/hour roting
(d) Other (Spocify)

16. Conirol Equipment NA
(a) Afterburnor on stock axit
-(b) Serubber $\square$
(c) Oither (Specity)
Typo
Typo

17. Rogulation Compliance

(a) Havo stack tosts boon porformod on tho unit? Yos $\square$ No Proposed Installation

(b) Are the results of the stock tests onclosod ond mado o port of this pormil application? Yas $\square$ No $\square$

(c) $Z_{1}$ o the results of the stock tosts on file in the Commission offico? Yos $\square$ No $\square$ 
DEP ARTAENT IOOR

NATURAL RESTiURCES AND

ENV IRONMENTAL PROTECTION

OIVISION OF AIR POLLUTIINN

FRANKFORT, KENTUCKY 40001

INCINERATORS ANO/OR WASTE BURNERS

Polnt of Enisesion Number 16-VA-6I

This secticen must be complotod for any aporatus used ms ignile and buen solid, liquid or goscous combustible wastes. It ms 1, 2, 3, and 4 are design criteria on the ir.cineropor manufocturer's name plate. The name plate should be in a conspicuous place on the incinerator.

1. Monufocturer' Nor : The Flare Tower is not purchased Data specific to the flare tower purchased will be supplied at a later date.

2. Andel Numbir Not yet Available

3. Roted C.apocity 16. por hour, or Not Yet Avail = rons por hour $\begin{array}{lllll}1 & 2 & 3 & 4\end{array}$ (5) $6^{\text {(Cirele Typo) }}$

5. Typa: 1). Inciner inr. Sing!, Chamber $\square]$ Multiple Chamber $\square$

2). Waste Eurner (tomper, runcored cono, siln, other) Elare Tower (a)

6. Are insinctions fo: the operation of the incineretor posted in a conspicuous ploce nee the incinerasor? Yos [.] No []. Not Applicable, New Installation

7. Quantity of waste lumed (0.0., ion 2 year, cubic yordvdoy, poundshour) Emergency Peak Flow (Circle coprogrtete uniss) 954,700 lbs/hr

8. Operorion setwodule:

Hours per doy

Wodis por yoer

9. Type of waste burned:
Doys por wouk Othor to be determined later

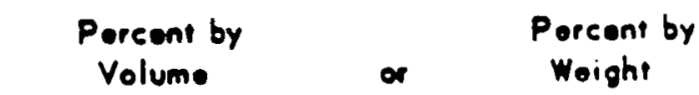

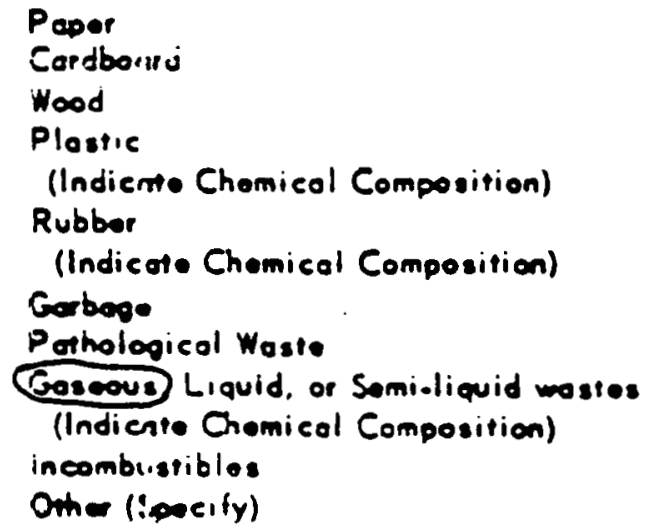

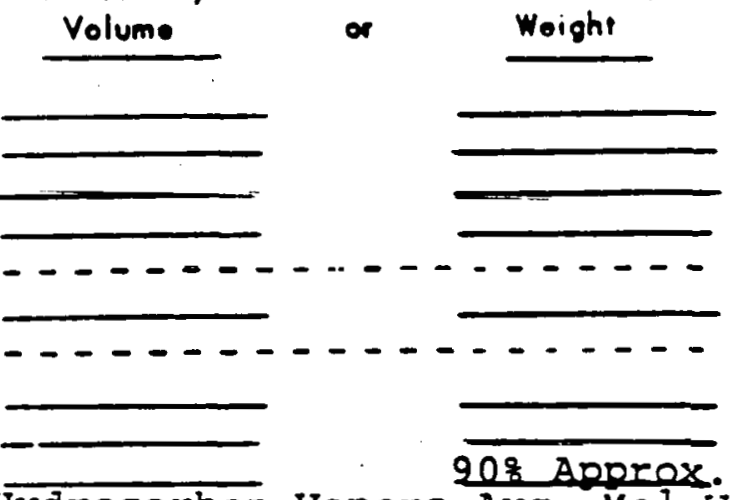

Hydracarbon Vapors Ayg..Mal.Wt. 60 109 Approx.

10. Phorogroph of unit. -nclose o minimum size photooroph of $5^{\prime} \times 7 \%$. Not Applicable, New Installation

11. Plor of the unit -.. manufocture's dewing or drowing eleaply lllustroting oll dimensions and construction derails me s: be aubmimaś.

Not Applicable, New Installation

(a) The total makeup of the flare system has yet to be completed. Currently one or more elevated flares with a controbled cumbustor and possibly an incinerator are being considered. See Section 8.0 
INCINERATORS ANO/OR WASTE BURNERS (cont'd)

12. Combir.inn A,r

(a) (i,cli
Noesrat Drate $X X$
Induced Drot?
Forcod Drat?
Pressure in. $\mathrm{H}_{2} \mathrm{O}$

(b) Air Distribution

Overfire Underfire Secondery

No. of Ports

Not Applicable

For Size (sq. n.)

Air Flow (SCF/A)

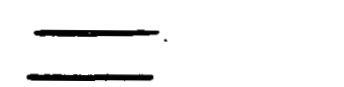

13. Srock
(a) Inside dioneter
48
inches
Estimated
(b) Hoighr obovo grotes to top of stock - 200 foet Estimated
(c) Height of stact above ony building or obstacle within 25 feet of the inciner atop
(di) Spain ivrestor Height - inches
Sereening openings
$-$
(e) Ster:k Snei!
Tyie of moieri di and th: ckness
Stee1
Tyre of refracion, thichiness and remperoture roting
Nane

14. Shell Construction
(a) Type of moreriol and thickness
Steel
(b) Tyine of insulation and thickness
(c) Type of rofraciory. thickness and rempereture rofing
(d) Type of sooms
(a) Maphod used tr. pie rofractory to outside shall

15. Auxiliary Equipmoirt
(a) Damper
Boromerric
Guillotine
None $\square$
(b) Primory burner (combustion chomber)
Fuel
BTU hour reting
(c) Sor:ondary burr:or
Fuel
BTU'hour rating
(d) Oiner (Soecity
Molecular seal, flame front generator for light-off. pilot gas system, knock out drum

16. Control Equipmont
(a) Atrerburner on srock exit $\square$ Type
(b) Scrubber $\square$
(c) Ollier ISpecity.
None
Typo

17. Rogulation Compliance
(a) Hijve stack iasts been performed on the unit?
(c) Aro the sesults of the stack tests on file in the Commission office? Yes $\square$ No
Not Applicable, New Installation 